UNIVERSIDADE DE SÃO PAULO

FACULDADE DE MEDICINA DE RIBIERÃO PRETO

DEPARTAMENTO DE BIOLOGIA CELULAR E MOLECULAR E BIOAGENTES

PATOGENICOS

PROGRAMA DE PÓS-GRADUAÇÃO EM BIOLOGIA CELULAR E MOLECULAR

JACKELINE SOUZA ARAÚJO

Caracterização funcional e da dinâmica espacial da miosina-Va no processo de fissão mitocondrial

Ribeirão Preto

2021 
JACKELINE SOUZA ARAÚJO

\section{Caracterização funcional e da dinâmica espacial da miosina-Va no processo de fissão mitocondrial}

Tese de Doutorado apresentada à Faculdade de Medicina de Ribeirão Preto da Universidade de São Paulo, para obtenção do título de Doutor em Ciências.

Área de concentração: Biologia Celular e Molecular.

Orientadora: Profa. Dra. Enilza Maria Espreafico

Versão corrigida. A versão original encontra-se disponível tanto na Biblioteca da Unidade que aloja o Programa, quanto na Biblioteca Digital de Teses e Dissertações da USP (BDTD).

Ribeirão Preto 
AUTORIZO A REPRODUÇÃO E DIVULGAÇÃO TOTAL OU PARCIAL DESTE TRABALHO, POR QUALQUER MEIO CONVENCIONAL OU ELETRÔNICO, PARA FINS DE ESTUDO E PESQUISA, DESDE QUE CITADA A FONTE.

\section{FICHA CATALOGRÁFICA}

Araújo, Jackeline Souza

Caracterização funcional e da dinâmica espacial da miosina-Va no processo de fissão mitocondrial.

Ribeirão Preto, 2021

$112 p$

Tese de Doutorado, apresentada à Faculdade de Medicina de Ribeirão Preto/USP. Área de concentração: Biologia Celular e Molecular.

Orientadora: Espreafico, Enilza Maria.

1. Miosina-Va. 2. Mitocôndria. 3. mitoSpire1. 4. Rab11a. 5. Melanoma 


\section{FOLHA DE APROVAÇÃO}

Jackeline Souza Araújo

\section{Caracterização funcional e da dinâmica espacial da miosina-Va no processo de fissão} mitocondrial.

Tese de Doutorado apresentada à Faculdade de Medicina de Ribeirão Preto da Universidade de São Paulo, para obtenção do título de Doutor em Ciências.

Área de concentração: Biologia Celular e Molecular.

Aprovada em: 29/03/2021

\section{Banca Examinadora}

Prof. Dr(a): Instituição:

Julgamento: Assinatura:

Prof. Dr(a): Instituição:

Julgamento: Assinatura:

Prof. Dr(a): Instituição:

Julgamento: Assinatura:

Prof. Dr(a): Instituição:

Julgamento: Assinatura:

Prof. Dr(a): Instituição:

Julgamento: Assinatura: 


\section{AGRADECIMENTOS PESSOAIS}

À memória dos meus pais, espero que todo meu crescimento pessoal e profissional faça vocês orgulhosos de mim, onde quer que estejam.

À minha tia Ângela, por ter me criado e me feito quem eu sou hoje. Sem você nada na minha vida seria possível, você é minha base. Obrigada por todo apoio e amor incondicional.

À toda minha família pela presença, amor e incentivo.

Ao meu namorado, Felipe, por todo amor, companheirismo e força. Obrigada por estar sempre ao meu lado de coração, me incentivar e acreditar tanto em mim.

A todos meus amigos do laboratório, Yasmin, Airton, Lucas, Santiago, Marcela, Rui, Johnny, Carlos, à memória do Maiaro, vocês sabem de toda importância que têm para mim, obrigada por terem me dado forças para chegar até aqui, por terem me aguentado todos esses anos, pelas ótimas conversas e convivência. Obrigada especial à Yasmin por todo companheirismo e ajuda com experimentos e revisão dos textos.

A todos meus outros amigos pela força, conselhos e companheirismo. Em especial à Iuly, por todas discussões astrológicas muito pertinentes.

Aos técnicos do laboratório, Joana, Silmara e Ricardo por tantos momentos alegres, conversas, apoio e conselhos. 


\section{AGRADECIMENTOS PROFISSIONAIS}

À minha orientadora Professora Dra Enilza Maria Espreafico que me acolheu em seu laboratório e me ajudou a desenvolver meu pensamento científico, me trazendo um grande crescimento profissional.

A todos os professores do Programa de Pós-Graduação em Biologia Celular e Molecular do Departamento de Biologia Celular e Molecular e Bioagentes Patogênicos da Faculdade de Medicina de Ribeirão Preto (FMRP), por todas as aulas, discussões científicas, que me moldaram uma pessoa mais crítica e sábia.

Ao Dr. Uri Manor do Instituto Salk por me receber em seu laboratório para execução de parte dos experimentos realizados nesse trabalho e aos colegas Salk Instituto por todos aprendizados.

Às secretárias do Programa de Biologia Celular e Molecular e Bioagentes Patogênicos da Faculdade de Medicina de Ribeirão Preto (FMRP), Gabriela, Camila e Lúcia, que sempre foram muito prestativas e não mediram esforços para me ajudar em processos administrativos.

Aos Laboratórios Multiusuários pelo apoio técnico, em especial ao Laboratório Multiusuário de Microscopia Confocal e Microscopia Multifóton, e as técnicas Bete e Roberta por todo auxílio sempre que necessário.

À agência de fomento Fundação de Amparo à Pesquisa do Estado de São Paulo (FAPESP) pelo apoio nos processos no 2016/10862-8 e 2019/19769-9.

Aos demais órgãos de fomento como Coordenação de Aperfeiçoamento de Pessoal de Nível Superior (CAPES), pela bolsa da Cota Institucional de Demanda Social, ao Conselho Nacional de Pesquisa (CNPq), Centro de Terapia Celular (CTC), Fundação de Apoio ao Ensino, Pesquisa e Assistência (FAEPA) do Hospital das Clínicas da Faculdade de Medicina de Ribeirão Preto e Fundação Hemocentro de Ribeirão Preto por toda infra-estrutura, auxílio administrativo e financeiro a mim concedido.

À Faculdade de Medicina de Ribeirão Preto (FMRP) e a Universidade de São Paulo. 


\section{RESUMO}

Araujo, Jackeline Souza. Caracterização funcional e da dinâmica espacial da miosina-Va no processo de fissão mitocondrial. 2021. Tese (Doutorado em Ciências) - Faculdade de Medicina de Ribeirão Preto, Ribeirão Preto.

A arquitetura mitocondrial está envolvida em várias funções cruciais para a viabilidade celular, como proliferação, senescência e sinalização. Em particular, a dinâmica mitocondrial através do equilíbrio entre fusão e fissão mitocondriais desempenha um mecanismo central para ajustar as necessidades metabólicas da célula. Recentemente, tem se dado um grande foco à participação do citoesqueleto e dos motores moleculares nos processos requeridos para homeostase mitocondrial. Em especial, a proteína mitoSpire1, uma proteína nucleadora de actina que possui localização mitocondrial, foi mostrada ser importante na fissão mitocondrial. Interessantemente, proteínas Spire interagem com os motores moleculares miosina- $\mathrm{V}$. A miosina-Va, um motor molecular dependente da actina, está envolvida em diversas funções cruciais para célula e dados já publicados do nosso laboratório indicam que ela também tem uma localização mitocondrial. Devido a isso, nós postulamos que a miosina-Va estaria envolvida nos processos de dinâmica mitocondrial. Para responder a estas questões, inicialmente nós confirmamos a localização da miosina-Va na superfície mitocondrial através de imagens confocais e de super-resolução. Posteriormente, vimos que a miosina-Va interage diretamente com mitoSpire1, e que seu recrutamento para MME aumenta com a superexpressão de mitoSpire1, tornando a sua interação mitocondrial ainda mais evidente. Para entendermos se a miosina-Va desempenha algum papel referente à mitocôndria, nós a modulamos em células de melanoma A375 através do silenciamento com shRNAs e do nocaute (KO) utilizando CRISPR. Observamos que estas células possuem mitocôndrias alongadas e com um menor número de eventos de fissão após a depleção da miosina-Va. Esse fenótipo é resgatado através da superexpressão de um construto contendo a miosina-Va inteira. Além disso, através de vídeo-microscopias nós observamos que a miosina-Va é localizada nos pontos de fissão mitocondrial, e que essa localização é parcialmente perdida em células KO para mitoSpire1. Em busca do mecanismo pelo qual a miosina-Va interfere na fissão mitocondrial, nós investigamos a sua interação com outras proteínas importantes deste processo. A partir disso, observamos que a localização da miosina-Va nos pontos de fissão mitocondrial coincide também com agrupamentos de Drp1, que é a principal proteína responsável pela fissão mitocondrial. Nossos dados também mostram a interessante localização conjunta da miosinaVa com Rab11a nos pontos de fissão mitocondrial, a qual também é parcialmente perdida em células KO para mitoSpire1. Por fim, nós vimos que as células KO para miosina-Va possuem menores taxas de consumo de oxigênio, quando comparadas com células controle, assim como menores níveis de produção de ATP. Em busca das consequências dessa menor eficiência energética, nós avaliamos algumas funções tumorigênicas das células, como a clonogenicidade e a migração, vimos que estas capacidades se encontram diminuídas após o KO da miosina-Va. Portanto, nossos dados são indicativos de um papel da miosina-Va na fissão mitocondrial, e nos indicam que possivelmente a miosina-Va, mitoSpire1 e Rab11a funcionem como um complexo proteico envolvido na regulação da fissão mitocondrial. Concluindo, a falta de função da miosina-Va provoca um desequilibro na fissão mitocondrial associada a uma menor eficiência energética, que leva a uma diminuição das propriedades tumorigênicas das células de melanoma A375 e podem explicar algumas das disfunções neuromusculares severas associadas com a Síndrome de Griscelli tipo 1.

Palavras chave: Miosina-Va, Mitocôndria, mitoSpire1, Rab11a, Melanoma. 


\begin{abstract}
Araujo, Jackeline Souza. Characterization of the functional and spatial dynamics of myosin Va in the mitochondrial fission process. 2021. Tese (Doutorado em Ciências) Faculdade de Medicina de Ribeirão Preto, Ribeirão Preto.
\end{abstract}

Mitochondrial architecture is involved in several crucial functions to cell viability, such as proliferation, senescence and signaling. In particular, mitochondrial dynamics through the balance between mitochondrial fusion and fission plays a central role in adjusting the cell metabolic needs. Recently, there has been a great focus on the participation of the cytoskeleton and molecular motors in the processes required for mitochondrial homeostasis. In particular, mitoSpire, an actin-nucleating protein that has a mitochondrial location, has been shown to be important in mitochondrial fission. Interestingly, Spire proteins interact with myosin-V molecular motors. Myosin-Va, an actin based molecular motor, is involved in a number of crucial cell functions, and published data from our laboratory indicate that it also has a mitochondrial location. In this context, we hypothesized that myosin-Va could be involved in the processes of mitochondrial dynamics. To answer these questions, we initially confirmed the localization of myosin-Va to mitochondria surface using super-resolution and confocal images. Later, we saw that myosin-Va interacts directly with mitoSpire1, and that its recruitment to the OMM increases with the overexpression of mitoSpire1, making myosin-Va mitochondrial interaction even more evident. To understand if myosin-Va plays a role in the mitochondria, we modulate it in A375 melanoma cells through knockdown with shRNA and also nocaute (KO) using CRISPR. We observed that these cells have elongated mitochondria and fewer fission events after myosin-Va depletion. This phenotype is rescued by overexpressing a construct containing the full length myosin-Va. In addition, through video microscopy we observed that myosin- $\mathrm{Va}$ is localized at mitochondrial fission points, and that this location is partially lost in mitoSpire $1 \mathrm{KO}$ cells. In search of the mechanism by which myosin-Va interferes with mitochondrial fission, we investigated its interaction with other important proteins in this process. We observed that the localization of myosin-Va at the mitochondrial fission points also coincides with clusters of Drp1, which is the central protein responsible for mitochondrial fission. Our data also show the interesting localization of myosin-Va and Rab11a to the mitochondrial fission points, which is also partially lost in mitoSpire1 KO cells. Finally, we found that $\mathrm{KO}$ cells for myosin-Va have lower oxygen consumption rates when compared to control cells, as well as lower levels of ATP production. In search for the consequences of this lower energy efficiency, we evaluated some tumorigenic functions of the cells, such as clonogenicity and migration, we observed that these capacities are reduced after myosin-Va KO. Therefore, our data are indicative of a role for myosin-Va in mitochondrial fission, and indicate that myosin-Va, mitoSpire1 and Rab11a could possibly act as a protein complex that is involved in the regulation of mitochondrial fission. In conclusion, myosin-Va depletion causes an imbalance in mitochondrial fission associated with lower energy efficiency, which leads to a decrease in tumorigenic properties of A375 melanoma cells and may explain some of the severe neuromuscular dysfunctions associated with the Griscelli syndrome-type 1.

Key words: Myosin-Va, Mitochondria, mitoSpire1, Rab11a, Melanoma. 


\section{LISTA DE ILUSTRAÇÕES}

Figura 1. Desenho estrutural da miosina-Va 17

Figura 2. Modelo esquemático dos eventos da fissão mitocondrial em células de mamíferos. ......................23

Figura 3. Modelo esquemático dos eventos da fissão mitocondrial em células de mamíferos......................25

Figura 4. A miosina-Va possui uma localização mitocondrial nas células A375. ..........................................42

Figura 5. A miosina-Va está presente na fração mitocondrial das células A375..........................................43

Figura 6. A miosina-Va interage com mitoSpire1..........................................................................................44

Figura 7. A miosina-Va é recrutada para a rede mitocondrial pela superexpressão da mitoSpire1.............46

Figura 8. A cauda da miosina-Va é recrutada para a mitocôndria por mitoSpire1 e se acumula nos locais de

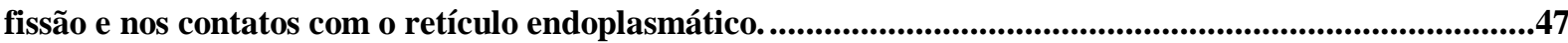

Figura 9. A miosina-Va endógena é recrutada para a MME pela superexpressão de mitoSpire1...............48

Figura 10. O nocaute da mitoSpire1 não interfere com a localização da cauda inteira da miosina-Va na rede

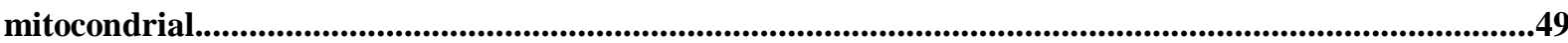

Figura 11. O silenciamento da miosina-Va promove mudanças na morfologia da rede mitocondrial.. .......50

Figura 12. Eficiência do nocaute de $M Y O 5 A$ nos clones das células A375.............................................51

Figura 13. Expressão da proteína miosina-Va em células A375 MYO5A KO após expansão clonal.............52

Figura 14. As células A375 MYO5A KO possuem alterações na morfologia mitocondrial. ..........................53

Figura 15. Fibroblastos humanos nulos para miosina-Va apresentam mitocôndrias mais alongadas do que fibroblastos humanos normais.

Figura 16. A superexpressão do construto da miosina-Va inteira leva a uma fragmentação da rede mitocondrial nas células A375 WT e A375 MYO5AKO.

Figura 17. A ultraestrutura mitocondrial é afetada pelo silenciamento da miosina-Va na linhagem celular A375.

Figura 18. A ultraestrutura mitocondrial é afetada pelo nocaute da miosina-Va na linhagem celular A375

Figura 19. MYO5A é o membro mais abundante da família MYO5 em células A375. A. qRT-PCR mostrando a expressão relativa dos transcritos $M Y O 5 A, M Y O 5 B$ e $M Y O 5 C$ em células A375.

Figura 20. O silenciamento da miosina-Vb e miosina-Vc com siRNAs não altera a morfologia mitocondrial de células A375.

Figura 21. Os nucleóides de mtDNA têm menor área e volume nas células A375 MYO5A KO. A ..............63

Figura 22. A superexpressão da miosina-Va inteira leva a uma reversão das alterações morfológicas dos nucleoides de mtDNA nas células A375 MYO5AKO.

Figura 23. O nocaute da miosina-Va não altera o número de cópias do mtDNA, assim como a expressão de PGC1a e TFAM.

Figura 24. O silenciamento da miosina-Va altera a expressão dos genes relacionados à dinâmica mitocondrial.

Figura 25. O silenciamento da miosina-Va altera a localização de proteínas relacionadas à dinâmica mitocondrial

Figura 26. A miosina-Va localiza-se nos pontoss de fissão mitocondrial.

Figura 27. O nocaute da mitoSpire1 diminui a localização da cauda inteira da miosina-Va nos locais de

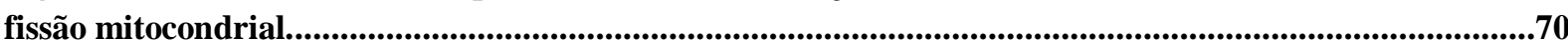

Figura 28. A miosina-Va se localiza juntamente com DRP1 em locais de fissão mitocondrial.. ...................72 Figura 29. O nocaute da mitoSpire1 diminui a localização da cauda inteira da miosina-Va, mas não de Drp1, nos locais de fissão mitocondrial

Figura 30. O nocaute de mitoSpire1 não interfere na colocalização entre Rab11a e a cauda da miosina-Va ou na localização de Rab11a nas mitocôndrias.

Figura 31. O nocaute da mitoSpire1 diminui a localização da da Rab11a e da cauda inteira da miosina-Va nos locais de fissão mitocondriais. 
Figura 33. As células depletadas para miosina-Va apresentam menores taxas de consumo de oxigênio

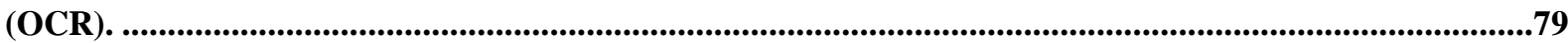

Figura 34. O nocaute da miosina-Va não altera as proteínas da cadeira respiratória mitocondrial. ...........80 Figura 35. O nocaute da miosina-Va não muda os níveis de acidificação extracelular...............................81 Figura 36. O nocaute da miosina-Va altera propriedades tumorigênicas das células de melanoma A375. .83 Figura 37. Modelo esquemático da atuação do complexo miosina-Va/mitoSpire1/Rab11a na fissão

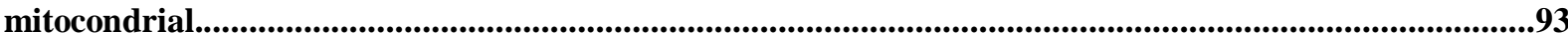


LISTA DE TABELAS

Tabela 1. Sequências dos shRNAs utilizados para o silenciamento do gene da MYO5A.

Tabela 2. Sequências dos primers utilizados para qRT-PCR. 


\section{SUMÁRIO}

1. INTRODUÇÃO-

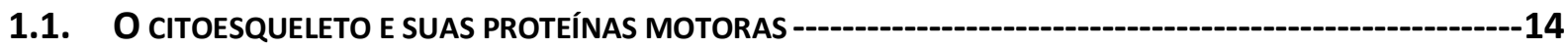

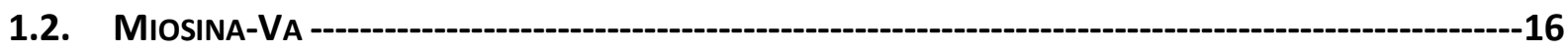

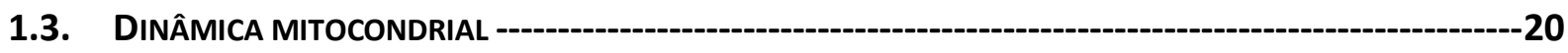

1.4. A RELAÇÃO TUMORAL---.--

2. OBJETIVOS-

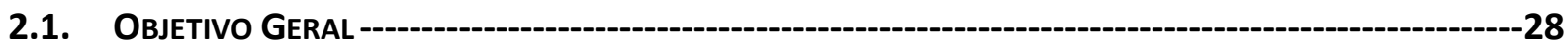

2.2. OвJetivos EsPecíficos -

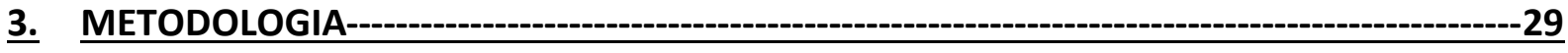

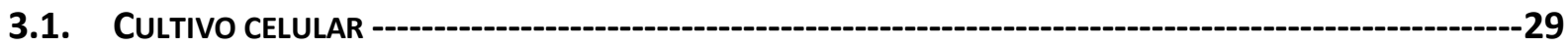

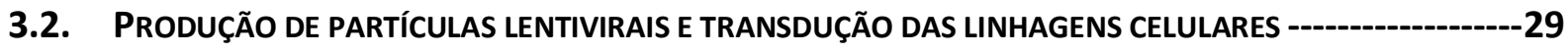

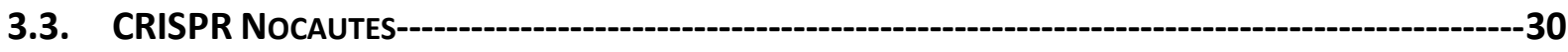

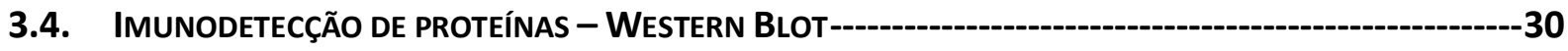

3.5. PURIFICAÇÃO DE DNA, RNA E QRT-PCR -

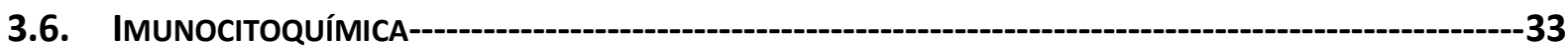

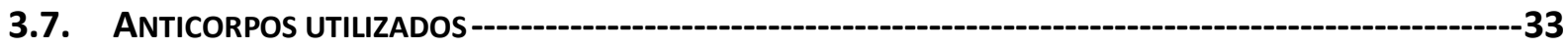

3.8. TRANSFECÇÃo de PROTEÍnAS FLUORESCENTES---

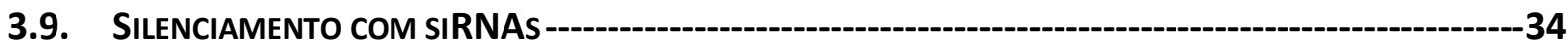

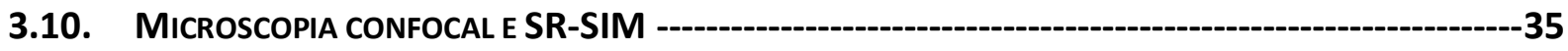

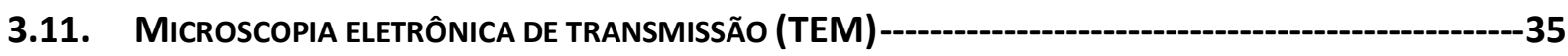

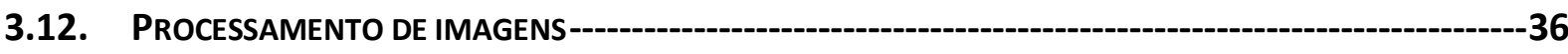

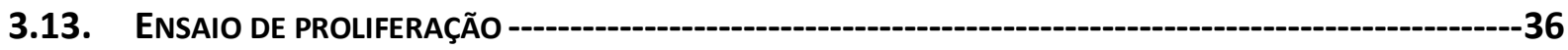

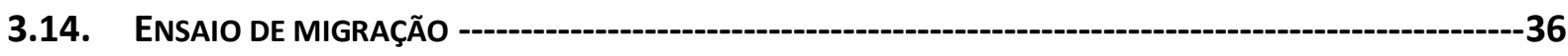

3.15. ENSAIO CLONOGÊNICO - -

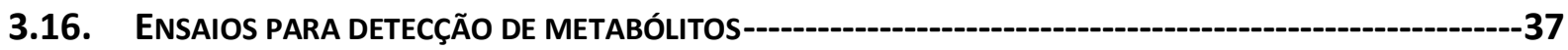

3.17. ENRIQUECIMENTO DA FRAÇÃO MITOCONDRIAL -------------------------------------------------------37

3.18. CONSUMO DE OXIGÊNIO E NÍVEIS DE ACIDIFICAÇÃO EXTRACELULAR. --------------------------------37

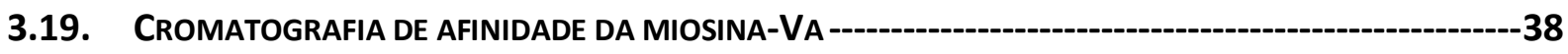

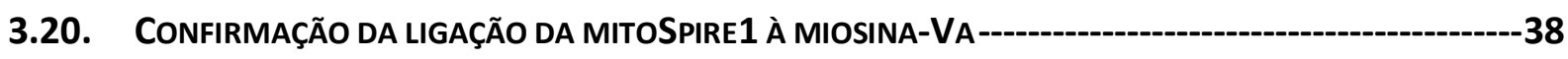




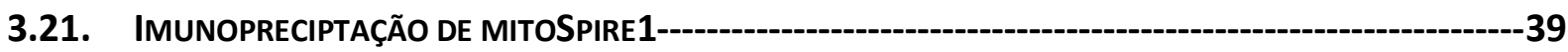

3.22. ESPECTOMETRIA DE MASSAS E ANÁLISE DE DADOS---

4.

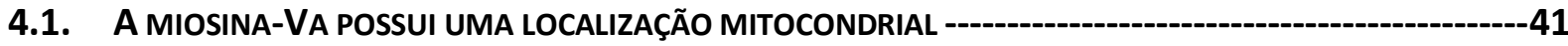

4.2. A MIOSINA-VA É RECRUTADA PARA MITOCÔNDRIA PELA MITOSPIRE1---:-

4.3. A DEPLEÇÃO DA MIOSINA-VA LEVA A UM ALONGAMENTO MITOCONDRIAL----------------------------49

4.4. A SUPEREXPRESSÃO DA MIOSINA-VA REVERTE O FENÓTIPO DE ELONGAÇÃO MITOCONDRIAL -----------55

4.5. A FALTA DA MIOSINA-VA LEVA A MUDANÇAS NA ULTRAESTRUTURA MITOCONDRIAL---------------57

4.6. EXPRESSÃO E INFLUÊNCIA DAS MIOSINAS DE CLASSE V NA MORFOLOGIA MITOCONDRIAL EM CÉLULAS A375 59

4.7. A DEPLEÇÃO DA MIOSINA-VA ALTERA A MORFOLOGIA DOS NUCLEÓIDES DE MTDNA ------62

4.8. A DEPLEÇÃO DA MIOSINA-VA E O BALANÇO DAS PROTEÍNAS DA DINÂMICA MITOCONDRIAL------------65

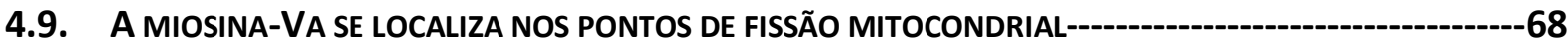

4.10. A MIOSINA-VA SE LOCALIZA NOS PONTOS DE FISSÃO MITOCONDRIAL JUNTAMENTE COM DRP1------71

4.11. A MIOSINA-VA SE LOCALIZA NOS PONTOS DE FISSÃO MITOCONDRIAL JUNTAMENTE COM RAB11A --74

4.12. A DEPLEÇÃO DA MIOSINA-VA LEVA A UMA DIMINUIÇÃO DOS EVENTOS DE FISSÃO MITOCONDRIAL---77

4.13. A DEPLEÇÃO DA MIOSINA-VA LEVA A MENORES TAXAS DE CONSUMO DE OXIGÊNIO ----------------78

4.14. AS CÉLULAS NOCAUTE PARA MIOSINA-VA NÃO APRESENTAM DIFERENÇAS NOS NÍVEIS DE ACIDIFICAÇÃO

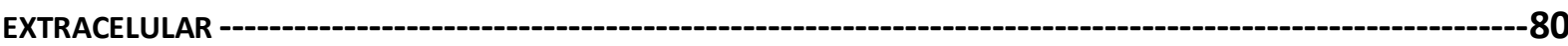

4.15. A DEPLEÇÃo DA MIOSINA-VA ALTERA PROPRIEDADES TUMORIGÊNICAS DAS CÉLULAS A375 --------81

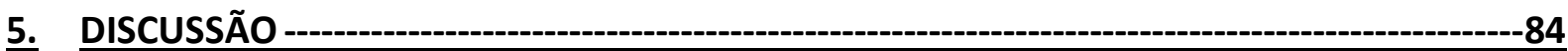

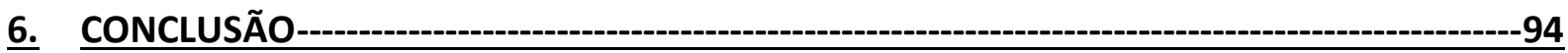

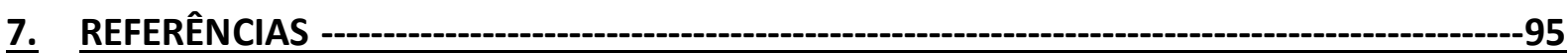

8. APÊNDICES - 


\section{Introdução}

\subsection{O citoesqueleto e suas proteínas motoras}

A conotação da palavra "esqueleto" muitas vezes pode nos remeter a algo fixo e estático. Porém o citoesqueleto celular é uma estrutura extremamente dinâmica e adaptativa, cujos componentes estão em constante fluxo. Temos três principais polímeros que formam o citoesqueleto de uma célula - filamentos de actina, microtúbulos, e filamentos intermediários (Fletcher and Mullins, 2010; Pollard and Goldman, 2018). A altamente regulada e ordenada montagem desses polímeros do citoesqueleto, juntamente com a ação dos seus motores moleculares associados, são responsáveis por três importantes funções: organizar os conteúdos da célula espacialmente; gerar força coordenada que capacita o movimento e a mudança de formato da célula; e conectar a célula ao ambiente externo, tanto física quanto bioquimicamente (Pollard, 2003).

$\mathrm{O}$ citoesqueleto de actina provém da montagem da actina globular (G-actina) em filamentos de dupla hélice (F-actina). A montagem e a desmontagem da F-actina é um processo altamente dinâmico, que envolve diversas proteínas regulatórias de acordo com a diversidade de funções que os filamentos de actina podem ter (Svitkina, 2018). Brevemente, a polimeração espontânea da G-actina é impedida principalmente por proteínas ligadoras de G-actina, como as profilinas e $\beta$-timosinas. Já a polimerização de novo de filamentos de actina é mediada por proteínas nucleadoras de actina ou por complexos de nucleação, sendo os principais: o complexo Arp2/3; as forminas; e as proteínas nucleadoras com domínio de ligação a actina em tandem, como as proteínas Spire, Cobl e leimodinas (Rottner et al., 2017).

Os microtúbulos são formados por heterodímeros de $\alpha$ - e $\beta$-tubulina, formando polímeros ocos e cilíndricos, geralmente de 13 protofilamentos. Os microtúbulos são polimerizados a partir do centro organizador de microtúbulos (MTOC), que geralmente tem uma localização centrossomal. Microtúbulos tem uma interessante característica chamada de "instabilidade dinâmica", que significa que a rede de microtúbulos pode passar rapidamente de um estado de crescimento estável para uma despolimerização rápida, chamada catástrofe. Isso faz com a rede de microtúbulos seja capaz de se reorganizar rapidamente, o que é altamente importante porque permite uma rápida adaptação da célula à fatores externos e internos (Goodson and Jonasson, 2018).

Tanto os filamentos de actina quanto os microtúbulos são estruturas polarizadas, o que 
faz com que as duas extremidades de cada polímero sejam diferentes entre si. A extremidade de crescimento mais rápida é denominada de extremidade mais (+), enquanto a de crescimento mais lento é denominada de extremidade menos (-). Como consequência dessa polaridade estrutural, cada polímero tem seus motores moleculares, que se movem preferencialmente em uma direção. Os motores moleculares associados ao microtúbulos são as dineínas, que se movem em direção à extremidade menos (-) do microtúbulos; e as cinesínas, que se movem em direção à extremidade mais (+) (Sweeney and Holzbaur, 2018). Já os motores moleculares associados ao citoesqueleto de actina são as proteínas membro da superfamília das miosinas, que por sua vez, se movem em direção à extremidade mais (+) do filamento de actina; com exceção da miosina VI, que apresenta um movimento em direção à extremidade menos (-) (Vale, 2003).

Todas as classes de mores moleculares convertem energia química em força motora a partir da hidrólise do ATP, que por sua vez gera uma mudança conformacional nos seus respectivos domínios motores que é traduzida em movimento. Outros domínios dos motores moleculares podem auxiliar na organização dos citoesqueletos de actina e microtúbulos, e também agir como reguladores dos processos de montagem e desmontagem das redes do citoesqueleto. Os motores moleculares também possuem seus domínios de interação com carga, que são responsáveis transportar e/ou ancorar organelas, complexos proteicos, vesículas, RNAs, entre outros componentes intracelulares. Por conseguinte, não seria surpreendente que defeitos na maquinaria de transporte dependente de motores moleculares estariam associados com uma ampla gama de doenças, incluindo neurodegeneração, tumorigênese e defeitos no desenvolvimento (Schliwa and Woehlke, 2003; Vale, 2003; Xiao et al., 2016).

Por fim, os filamentos intermediários são formados por uma grande classe de proteínas que são codificadas por pelo menos 70 genes. Diferentemente dos filamentos de actina e dos microtúbulos, os filamentos intermediários não são polarizados e não suportam o movimento de motores moleculares (Hohmann and Dehghani, 2019). Esses filamentos podem resistir a forças tensoras com bastante eficiência e podem ser utilizados como mecanismo de resposta à estresses mecânicos, como por exemplo, em células do epitélio das vias aéreas (Fletcher and Mullins, 2010). Uma classe muito importante e altamente expressa de filamentos intermediários são as laminas nucleares, que contribuem para a integridade do núcleo das células, e também, podem ser um fator regulatório para o começo da mitose (Tsai et al., 2006).

Revisões mais detalhadas e abordando mais detalhes sobre os filamentos do citoesqueleto, e os diferentes motores moleculares, foram publicadas por Fletcher and Mullins, 
2010; Hohmann and Dehghani, 2019; e Schliwa and Woehlke, 2003; dentre outras, e podem ser consultadas para maiores informações. Como grande parte deste trabalho tem como foco o motor molecular miosina-Va, apresentaremos uma visão mais aprofundada sobre ela.

\subsection{Miosina-Va}

Miosinas são motores moleculares dependentes de actina e possuem uma grande diversidade de funções nas células, incluindo a contração muscular, divisão celular durante a citocinese, transporte de diversas cargas intracelulares, manutenção da adesão célula-célula e célula-substrato, além da participação na motilidade celular. A superfamília das miosinas é composta de mais de 30 classes de proteínas. Em células humanas, são expressas 40 miosinas diferentes, pertencentes a 12 classes (Odronitz and Kollmar, 2007; Sebé-Pedrós et al., 2014).

A classe das miosinas $\mathrm{V}$ é uma das mais complexas entre as diversas classes já identificadas da superfamília de miosinas, além de uma das classes mais conservadas evolutivamente, sendo que seus membros foram caracterizados em diversos organismos. Em humanos, foram identificados três membros de miosinas da classe $\mathrm{V}$ : miosina- $\mathrm{Va}$; miosina- $\mathrm{Vb}$ e miosina-Vc (Cheney, Riley, et al., 1993; Cheney and Rodriguez, 2001; Masters et al., 2017).

Todas as miosinas conhecidas possuem uma estrutura similar em suas cadeias pesadas, que podem ser divididas em três domínios principais: motor, pescoço e cauda. O domínio motor é altamente conservado entre todas as classes de miosinas e se localiza na região N-terminal, e é responsável pela hidrólise do ATP, além de possuir o sítio de ligação à actina. $\mathrm{O}$ ciclo da ATPase é interligado às mudanças conformacionais e à capacidade de ligação do motor à actina. A miosina-Va age como um dímero, ou seja, é formada por duas cadeias pesadas e, portanto, contém duas cabeças. Os ciclos de ATP das duas cabeças idênticas são escalonados, de modo que pelo menos uma das cabeças é fortemente ligada à actina em um dado momento.

O domínio pescoço atua como um braço de alavanca mecânica, e amplifica as mudanças conformacionais do domínio motor em forma de deslocamento. É composto por diversos motivos IQ (motivos de isoleucina-glutamina) que formam uma $\alpha$-helix que pode conter a ligação de várias calmodulinas ou cadeias leves regulatórias. A quantidade de domínios IQ geralmente dita a processividade e o tamanho dos passos da miosina nos filamentos de actina (Purcell et al., 2002). Na classe de miosina-Va, especificamente, o domínio pescoço possui seis domínios IQ (com a sequência IQxxxRGxxxR) (Espreafico et al., 1992; Cheney, O'shea, et al., 1993).

Por fim, temos o domínio cauda, que pode ser dividido em subdomínios. Na miosina- 
Va temos os subdomínios da cauda proximal, cauda medial e cauda globular. As regiões da cauda proximal e medial se localizam logo após os domínios IQ, e são formadas por uma estrutura coiled-coil. Este segmento é responsável por dimerizar as duas cadeias pesadas da miosina-Va e facilitar o movimento ao longo do filamento de actina, além de também facilitar o dobramento da proteína. Já o domínio da cauda globular, é altamente variável entre as classes de miosinas, e é responsável por se ligar a cargas específicas (Espreafico et al., 1992; Thirumurugan et al., 2006; Zhang et al., 2018). Na miosina-Va, esta região foi associada com a ligação de diversos receptores de carga, além de também conter sítios de splicing alternativo que permitem uma maior diversidade e seletividade de ligação de carga. A miosina-Va, devido a sua dimerização, também possui dois domínios globulares (Pashkova et al., 2006; Zhang et al., 2016). A Figura 1 apresenta detalhes da estrutura da miosina-Va.

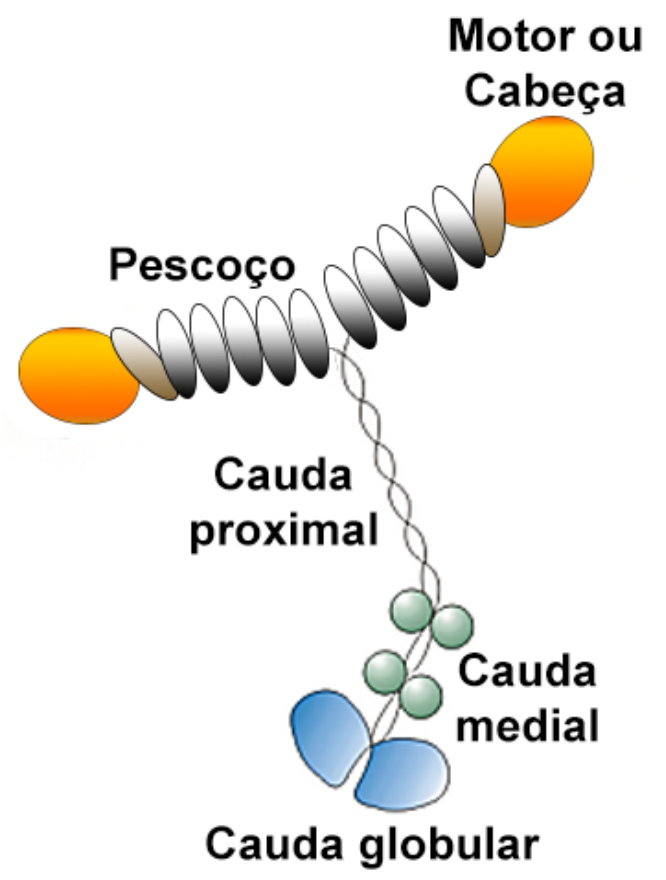

Figura 1. Desenho estrutural da miosina-Va. Na parte N-terminal da miosina-Va está o domínio motor ou cabeça que contém os sítios de ligação ao ATP e actina. A cabeça é seguida pelo domínio pescoço que consiste em seis motivos IQ, os quais agem como sítos para ligação de calmodulina (cinza) ou cadeias leves semelhantes a calmodulina (marrom). Em seguida, temos o domínio cauda, que pode ser subdivido em cauda proximal, medial e globular. Na cauda proximal e medial temos a presença de cinco regiões coiled-coils separadas for quatro hastes flexíveis. Adapatado de (Izidoro-Toledo et al., 2013).

A miosina-Va tem a sua atividade ATPásica dependente de cálcio, e além disso, o cálcio também induz mudanças conformacionais na sua estrutura (Espindola et al., 1992; Krementsov et al., 2004; Wang et al., 2004). Foi proposto um modelo de regulação da miosina-Va baseado 
na sua inibição pela cauda globular, onde a ausência de cálcio faz com que o domínio da cauda globular da miosina-Va se ligue ao seu domínio motor, tornando a proteína inativa, nessas condições a miosina-Va assume uma conformação dobrada e triangular. Essa inativação é revertida pela presença de cálcio e/ou de proteínas adaptadoras, quando a miosina-Va assume uma conformação estendida (Li et al., 2005; Liu et al., 2006; Zhang et al., 2018).

A miosina-Va realiza o transporte e a ancoragem de suas cargas através da interação com algumas proteínas adaptadoras no seu domínio cauda, tanto na parte da cauda proximal quanto na parte da cauda globular (Zhang et al., 2018). As principais proteínas adaptadoras que interagem com a miosina-Va são as proteínas membros da família de Rab GTPases. As proteínas Rab são reguladores centrais de todos os aspectos de tráfego intracelular, incluindo o brotamento, capeamento, mobilidade, ancoragem e fusão de vesículas (Kelly et al., 2012; Pylypenko et al., 2018). Elas possuem um papel tão amplo devido à sua capacidade de, quando no estado ativo ligado ao GTP, se ligarem a diversas proteínas efetoras que medeiam tais funções. Já foi demonstrada a interação da miosina-Va a partir do seu domínio cauda com as Rabs 3, 6, 8, 10, 11, 14, 25 e 39 (Lindsay et al., 2013). Além disso, a miosina-Va também interage indiretamente com a Rab27a através da melanofilina, uma proteína efetora de Rab (Fukuda et al., 2002; Hume et al., 2002).

A interação entre a miosina-Va, Rab27a e melanofilina é um dos complexos mais estudados e bem caracterizados dos quais a miosina-Va faz parte. Juntamente, essas proteínas estão evolvidas no transporte de melanossomos, em melanócitos (Strom et al., 2002; Wu, X. et al., 2002; Nascimento et al., 2003). Os melanossomos são organelas, similares a lisossomos, especializadas na produção de melanina, um pigmento capaz de absorver a luz e assim, é responsável pela proteção contra os dados da radiação UV. Os melanossomos maduros necessitam ser transportados para a periferia dos melanócitos, onde a melanina é transferida para os queratinócitos vizinhos atuando na coloração da pele e cabelos (Nascimento et al., 2003). Este transporte dos melanossomos para a periferia celular se dá de duas maneiras. A primeira envolve os microtúbulos em um transporte bidirecional chamado de "longo alcance", no qual os melanossomos são levados do centro da célula até a região cortical, e de volta para o centro da célula através dos motores moleculares dineínas e cinesinas (Vancoillie et al., 2000a; b). Uma vez no córtex da célula, se dá o segundo tipo de transporte, que envolve os filamentos de actina e é chamado de transporte de "curto alcance". Nesse caso, o complexo formado pela miosina-Va, melanofilina e Rab27a é responsável pela ancoragem dos melanossomos na rede cortical de actina, impedido que eles voltem para centro da célula através 
dos microtúbulos, e permitindo assim, que a melanina seja liberada para os queratinócitos (Da Silva Bizario et al., 2002; Fukuda et al., 2002; Westbroek et al., 2003).

Mutações em qualquer desses genes são causadoras da Síndrome de Griscelli uma doença autossômica recessiva rara, comumente caracterizada pela pouca ou nenhuma coloração da pele e do cabelo dos indivíduos afetados devido à defeitos no transporte dos melanossomos (Van Gele et al., 2009). A Síndrome de Griscelli é classificada em três tipos de acordo com o gene mutado: tipo 1 é causada por mutações no gene da miosina-Va; tipo 2 por mutações no gene da Rab27a; e tipo 3 que é causada por mutações no gene da melanofilina. Especificamente, mutações no gene da miosina-Va levam ao tipo 1 desta síndrome que, além da hipopigmentação, geralmente vem acompanhada de sérios comprometimentos neurológicos (Pastural et al., 1997; Ménasché et al., 2002), os quais podem ser explicados pela importância da miosina-Va no transporte de vesículas secretórias e sinápticas no cérebro (Rudolf et al., 2011).

A miosina-Va é ubiquamente distribuída nas células e várias linhas de evidência postularam funções muito mais amplas para a miosina-Va, além do transporte de melanossomos. Por exemplo, a miosina-Va é concentrada nos centrossomos, e em células ciliadas interfere no desenvolvimento do cílio primário (Espreafico et al., 1998; Assis et al., 2017). Também foi demonstrado através de trabalhos de localização celular que a miosina-Va se associa com espículas nucleares (Pranchevicius et al., 2008), e com diversas organelas citoplasmáticas, como o retículo endoplasmático (RE), complexo de Golgi, endossomos, peroxissomos, e a mitocôndria (Takagishi et al., 1996; Nascimento et al., 1997). A miosina-Va também foi relacionada com diversos processos de células cancerígenas, como sua interação com PTEN (Van Diepen et al., 2009), com Bcl-xL (Du et al., 2007); além da miosina-Va também ser regulada positivamente por Snail, promovendo invasão celular (Lan et al., 2010).

A relação da miosina-Va em processos tumorais é bem descrita no melanoma. A miosina-Va é hiper-regulada em células de melanoma metastático e é requerida para a manifestação das propriedades malignas dessas células, como por exemplo, a sobrevivência independente de ancoragem, migração e invasão (Alves et al., 2013). A miosina-Va também foi postulada por ser um alvo de MITF (Alves et al., 2017), um importante fator de transcrição responsável por propriedades malignas do melanoma. Além disso, a miosina-Va é capaz de modular a apoptose iniciada pela indução da permeabilização da membrana mitocondrial externa (MOMP) através da modulação do fator pró-apoptótico Bmf (Puthalakath et al., 2001). É possível induzir a apoptose de células de melanoma a partir da interferência neste processo 
pela superexpressão de um pequeno fragmento da cauda da miosina-Va (Izidoro-Toledo et al., 2013), este fragmento se liga fortemente a proteína DLC2 impedindo que a DLC2 se ligue a Bmf, e assim a Bmf fica disponível para desencadear a apoptose.

Como dito anteriormente, também já foi observada a presença da miosina-Va na mitocôndria (Takagishi et al., 1996; Nascimento et al., 1997); e interessantemente, Myo2p, proteína ortóloga à miosina-Va em leveduras, é requerida para o transporte mitocondrial e para correta herança mitocondrial pelas células filhas após a mitose em Saccharomyces cerevisiae (Boldogh et al., 2004; Förtsch et al., 2011). Em mamíferos, a miosina-Va tem um papel no metabolismo energético através da mediação do transporte de vesículas contendo GLUT4 em adipócitos e células musculares (Yoshizaki et al., 2007; Chen et al., 2012; Sun et al., 2014). Porém, há poucas observações sobre o efeito da miosina-Va sobre a rede mitocondrial. Já foi observado que o silenciamento da miosina-Va em neurônios leva a um aumento no tamanho das mitocôndrias (Pathak et al., 2010). Estudos recentes demonstram que a miosina-Va interage com a proteína mitoSpire1 e agem em conjunto na ancoragem e posicionamento da mitocôndria em compartimentos subcelulares (Straub et al., 2020), se opondo ao movimento das mitocôndrias baseado na rede de microtúbulos (Saxton, 2018). A mitoSpire1 é uma proteína nucleadora de actina pertencente à família das Spire, e, além de se localizar na membrana mitocondrial externa (MME), também já foi relacionada como tendo uma função na dinâmica mitocondrial (Manor et al., 2015). A proteínas Spire interagem com ambas miosina-Va e miosina- $\mathrm{Vb}$ através de um domínio conservado na região central da cauda globular das miosinas-V (Pylypenko et al., 2016). Essa interação, juntamente com os dados relatados acima, são um forte indicativo para um papel da miosina-Va na dinâmica mitocondrial.

\subsection{Dinâmica mitocondrial}

Mitocôndrias são organelas semiautônomas que possuem o seu próprio genoma e maquinaria de síntese proteica. A ultraestrutura mitocondrial, que pode ser visualizada por microscopia eletrônica, é caracterizada por um sistema de dupla membrana. A membrana mitocondrial externa (MME) é voltada para o citosol, e a membrana mitocondrial interna (MMI) é voltada para a matriz mitocondrial. O compartimento entre as membranas externa e interna é chamado de espaço intermembranas (Labbé et al., 2014). A membrana interna forma protrusões em direção a matriz mitocondrial que são chamadas de cristas mitocondriais e acomodam os complexos da cadeia respiratória (Cogliati et al., 2016). O papel clássico da mitocôndria é o suprimento de energia da célula a partir da produção de ATP, que é gerado 
através da fosforilação oxidativa nas cristas mitocondriais (Chandel, 2015). Este processo gera espécies reativas de oxigênio (EROS) como subprodutos, que podem agir como moléculas de sinalização fisiológica ou induzir toxicidade quando produzidas em excesso (Shadel and Horvath, 2015).

Nas últimas décadas, o conceito de que as mitocôndrias eram organelas estáticas e isoladas que serviam apenas como "powerhouses" para a célula tornou-se obsoleta (Westermann, 2010; Tilokani et al., 2018; Rastogi et al., 2019). Com o desenvolvimento de novas tecnologias que permitiram o rastreamento das mitocôndrias em células vivas, pudemos observar como as mitocôndrias continuamente se movem e adaptam suas formas através da fissão e fusão mitocondrial (Chandel, 2015; Tilokani et al., 2018). Os processos de fusão e fissão mitocondrial são coletivamente conhecidos como dinâmica mitocondrial e esses processos estão envolvidos em várias funções cruciais para a célula, como viabilidade celular, apoptose, imunidade, adaptação bioenergética e controle de qualidade mitocondrial (Otera et al., 2013; Nasrallah and Horvath, 2014; Mishra and Chan, 2016; Chen and Chan, 2017). Além disso, o desequilíbrio do balanço entre os processos de fissão e fusão é um fator causal para o início de doenças neurodegenerativas, câncer e envelhecimento (Suen et al., 2008; Youle and Van Der Bliek, 2012; Mishra and Chan, 2014; Giampazolias and Tait, 2015; Bordi et al., 2017), o que destaca a relevância da dinâmica mitocondrial para a homeostase celular.

Os principais componentes que regulam a dinâmica mitocondrial são proteínas GTPase pertencentes à família das dinaminas. A fissão é regulada através do recrutamento de Drp1 (Dynamin-related protein 1) (Otera et al., 2013) pelas suas proteínas adaptadoras, tais como MFF, MiD49/51 e Fis1 (Zhao et al., 2011; Loson et al., 2013). A fusão é regulada principalmente por Mfn1 e Mfn2, que atuam na membrana mitocondrial externa (MME), e Opa1, que atua na membrana mitocondrial interna (MMI) (Macvicar and Langer, 2016). A nível molecular, a fissão é importante para segregação da população de mitocôndrias de uma célula durante a mitose. Além disso, a existência de mitocondriais menores facilita o transporte dessas organelas para pontos necessários na célula. Este último é especialmente importante em neurônios que possuem longos axônios. Já fusão mitocondrial é importante para manter a população mitocondrial de uma célula homogênea a partir da mistura dos componentes mitocondriais. Esse processo também é importante para diminuir o stress mitocondrial, uma vez que pode misturar os conteúdos de uma mitocôndria parcialmente danificada com uma saudável, fazendo uma forma de complementação.

Antes do evento de fissão propriamente dito, a mitocôndria passa por uma pré- 
constrição, que ocorre nos pontos de contato entre o RE e a mitocôndria. Os túbulos do RE não apenas fazem contato com a mitocôndria, mas também se enovelam ao redor dela levando a essa constrição (Friedman et al., 2011). Este processo ocorre com ajuda dos filamentos de actina que são polimerizados ao redor da mitocôndria nos pontos marcados pelo RE, por duas proteínas: INF2 (Inverted Formin 2) e mitoSpire1 (Hatch et al., 2014; Li et al., 2015). INF2 é localizada na membrana do RE (Korobova et al., 2013; Chakrabarti et al., 2018) e a mitoSpire1 é localizada na membrana mitocondrial externa (Manor et al., 2015), ambas contribuem para a polimerização de actina ao redor da mitocôndria. Em adição, também já foi mostrado que a miosina-II possivelmente possibilita esta constrição gerando força mecânica através dos filamentos de actina polimerizados no local (Korobova et al., 2014; Yang and Svitkina, 2019). Além deste passo ser importante na constrição do túbulo mitocondrial, a ação concomitante do RE e dos filamentos de actina são cruciais reguladores da fissão mitocondrial, sendo que os filamentos de actina também são responsáveis estimular o recrutamento e a oligomerização da Drp1 (Ji et al., 2015; Hatch et al., 2016).

Embora seja bem conhecido que o RE e a polimerização da actina são necessários para os passos iniciais da divisão mitocondrial, até recentemente não estava claro como o RE e o Drp1 identificavam os locais adequados para a fissão mitocondrial. Lewis e colaboradores (2016) mostraram que a replicação do mtDNA é um passo que antecede a fissão mitocondrial. Uma vez que o mtDNA replicante é espacialmente associado aos locais de contato das mitocôndrias e RE e aos locais de constrição mitocondrial, foi postulado que a replicação do mtDNA é um evento regulador pra os pontos de pré-constrição mitocondrial. Essa regulação espacial permitiria a distribuição do mtDNA para as novas mitocôndrias "filhas" após a fissão mitocondrial (Lewis et al., 2016).

O recrutamento da Drp1 é um passo essencial para a fissão mitocondrial. Drp1 é uma proteína predominantemente citosólica que é dinamicamente recrutada para membranas da mitocôndria, onde se oligomeriza e dirige a fissão mitocondrial. Na MME, a Drp1 se oligomeriza em forma de anel ao redor da mitocôndria, e então a hidrólise do GTP pela Drp1 leva a contrição da membrana que marca um ponto de fissão. Recentemente, foi visto que Drp1 mantém um equilíbrio dinâmico entre o citosol e a mitocôndria, além de estar constantemente interagindo com a MME "procurando" por sinais indutores de fissão. Foi visto também, que a maturação de Drp1 em oligômeros estáveis e produtivos ao redor da mitocôndria só se forma em pontos específicos onde há sinais para fissão mitocondrial. A pré-constrição realizada pelo RE e os filamentos de actina são alguns destes pontos. As proteínas adaptadoras de Drp1, que 
em mamíferos são MFF e MiD49/51, são importantes também para o seu recrutamento, porque Drp1 não possui um domínio de ligação direta a membranas.

Apesar do papel e da importância da Drp1 para fissão mitocondrial ser muito bem descrito, sempre foi questionada a sua capacidade de promover a cisão propriamente dita da mitocôndria. Estudos utilizando a técnica cryo-EM mostraram que em leveduras a Dnm1 (análoga a Drp1 de mamíferos) atingia uma constrição máxima de 50-60nm (Naylor et al., 2006), sugerindo que a cisão final requeria um mais um passo. Foi então que, recentemente, foi demonstrado que a Dnm2, um membro da família convencional de dinaminas, age após a Drp1, no passo final da cisão mitocondrial. Experimentos de imagens em células vivas demonstraram que a Dnm2 é especificamente recrutada pra pontos de fissão em que há presença ativa da Drp1, e que a Dnm2 realiza o passo final da fissão mitocondrial (Lee et al., 2016). A figura 2 sumariza os eventos da fissão mitocondrial.

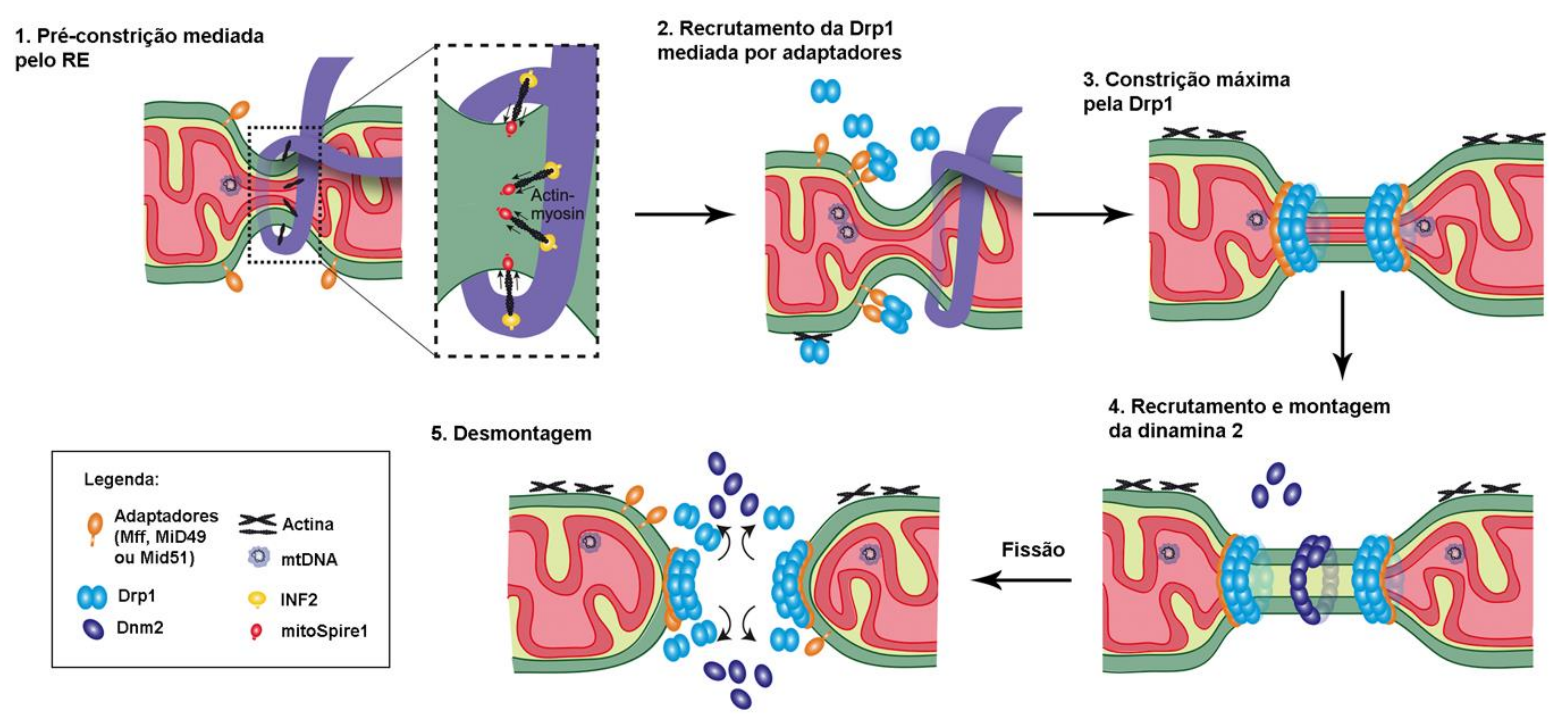

Figura 2. Modelo esquemático dos eventos da fissão mitocondrial em células de mamíferos. Na primeira etapa ocorre a pré-constrição das mitocôndrias pela maquinaria de constrição do RE, que foi postulada por ocorrer em sítios de replicação dos nucleóides mitocondriais. A imagem ampliada mostra INF2 localizada no RE iniciando a nucleação dos filamentos de actina, que se associam com as mitocôndrias através da proteína mitoSpire1. Os filamentos de actina em crescimento, juntamente com a miosina-II, exercem pressão sobre a membrana mitocondrial externa. Na segunda etapa, ocorre a ligação dos adaptadores da Drp1 (Mff, MiD49 ou Mid51, dependendo do tipo celular) no futuro local da fissão, o que facilita o recrutamento de Drp1. Após a montagem dos adaptadores, os dímeros Drp1 são recrutados para o local de fissão. Diferentes formas oligoméricas de Drp1 podem ser recrutadas para a superfície mitocondrial, e ocorre a montagem do anel contrátil de Drp1 no pescoço da MME. Na terceira etapa ocorre a hidrólise de GTP gerando mudanças conformacionais, mediando assim a constrição final de Drp1. Por fim, na quarta etapa ocorre o recrutamento da Dnm2. Neste ponto proteínas adaptadoras Dnm2 adicionais podem estar envolvidas. Após a hidrólise do GTP, ocorre mais uma etapa de constrição para completar a fissão, e em seguida a maquinaria de fissão é desmontada. Adaptado de (Kraus and Ryan, 2017). 
O exato mecanismo pelo qual ocorre a fusão mitocondrial ainda é incerto, provavelmente porque as proteínas Mfn e Opal foram as últimas da família das dinaminas a terem suas estruturas estudadas (Daumke and Praefcke, 2018; Gao and Hu, 2020). As Mfn são descritas como moléculas com um formato de $\mathrm{V}$, ancoradas na MME através de dois domínios de hélices transmembranares. Também possuem um domínio GTPase, o qual permite a interação entre as Mfn e hidrólise do GTP (Cao et al., 2017; Li et al., 2019). As proteínas Mfn são necessárias na MME das duas mitocôndrias prestes a se fusionarem, portanto, a interação em trans das Mfn é essencial para fusão. A interação em trans dos domínios GTPase de duas Mfn estimula a hidrólise do GTP, que por sua vez promove uma mudança conformacional nas Mfn, o que arrasta as membranas mitocondriais opostas até que fiquem justapostas (Koshiba et al., 2004; Cao et al., 2017). Foi mostrado que alguns domínios da proteína da proteína Mfn1 conseguem desestabilizar membranas, quando em peptídeos isolados (Daste et al., 2018), o que sugere que este seja o passo final da fusão da MME.

Assim que se concretiza a fusão da MME, é necessário que também haja a fusão da MMI, a qual é mediada pela proteína Opa1. Opa1 é uma GTPase evolutivamente conservada e complexa, possuindo oito variantes de splicing (Griparic et al., 2007; Anand et al., 2014; Macvicar and Langer, 2016). É importante também destacar que a Opa1 tem diversas outras funções, além da fusão das MMI. Devido a sua complexidade, e suas muitas variantes de splicing, ela pode agir de diferentes maneiras, de acordo com as necessidades da célula. A Opa1 é responsável também pela manutenção do mtDNA e sua ancoragem na MMI (Elachouri et al., 2011), participa da organização da crista mitocondrial e da localização dos supercomplexos da cadeia respiratória (Cogliati et al., 2013; Cogliati et al., 2016), regula a apoptose a partir da compartimentalização do citocromo c (Frezza et al., 2006) e regula a homeostase mitocondrial de cálcio nos locais de contato entre a mitocôndria e o RE (Fülöp et al., 2015).

Opa1 se insere na MMI via sua parte N-terminal, e a maioria desta proteína fica exposta no espaço intermembranas (Olichon et al., 2002). Em mamíferos, a localização da Opa1 em apenas uma de duas mitocôndrias opostas é necessário para dirigir a fusão das suas membranas internas (Song et al., 2009). Estudos mostram que a composição lipídica das membranas e em particular a cardiolipina, um lipídio específico das membranas mitocondriais, tem um papel na remodelação e na dinâmica das membranas mitocondriais (Devay et al., 2009; Rujiviphat et al., 2009; Ban et al., 2017). A incubação da Opa1 recombinante com lipossomos formados por cardiolipina levam a uma interação da Opa1 com a cardiolipina, o que leva a fusão das membranas (Ban et al., 2017). Por fim, a fusão da MMI pela Opa1 necessita da presença da 
Mfn1, o que sugere uma comunicação entre a MME e a MMI e também uma possível interação entre Opa1 e Mfn1 para regularem em conjunto o processo de fusão mitocondrial (Cipolat et al., 2004). A figura 3 sumariza os eventos da fusão mitocondrial.
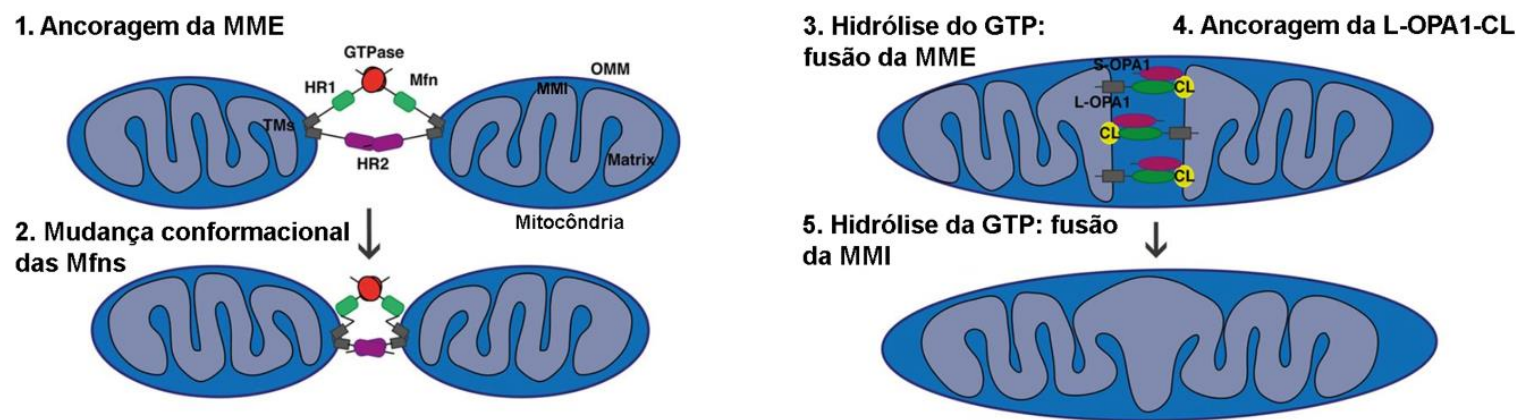

Figura 3. Modelo esquemático dos eventos da fissão mitocondrial em células de mamíferos. Esta representação esquemática da fusão mitocondrial foi feita com base na topologia das Mfns, sugerindo dois domínios transmembranares (TM) com ambos os domínios HR1 e HR2 voltados para o citosol. Na primeira etapa a membrana externa de duas mitocôndrias opostas são justapostas pela interação em trans dos domínios HR2 e domínios GTPase das Mfns. A interação dos dois domínios GTP induz uma mudança conformacional nas Mfns levando à ancoragem das mitocôndrias e a um aumento dos locais de contato das membranas. Na terceira etapa vemos que a hidrólise do GTP leva à fusão da MME através da desestabilização das membranas. A composição de lipídeos da MME também pode regula este processo. Na quarta etapa, após a fusão da MME, OPA1 e o lipídeo cardiolipina (CL) conduzem a fusão da MMI. A interação entre OPA1 e CL em qualquer um dos lados das membranas ancora as MMIs, que se fundem após a hidrólise de GTP dependente de OPA1. Neste modelo, SOPA1 (isoforma small da OPA1) demonstrou melhorar a interação entre L-OPA1 (isoforma large da OPA1) e CL e também a fusão. Adaptado de (Tilokani et al., 2018)

\subsection{A relação tumoral}

Nos últimos anos tem se tornado aparente que a mitocôndria tem papéis chaves em várias características do câncer, como por exemplo regulando a morte celular programada, regulação do metabolismo, inflamação, instabilidade genômica e migração (Hanahan and Weinberg, 2011; Giampazolias and Tait, 2015). A primeira vez que a mitocôndria chamou atenção em relação à tumorigênese foi quando Otto Warburg (1956) descreveu que células cancerosas geraram preferencialmente ATP a partir da glicólise, mesmo na presença de oxigênio e apesar da glicólise ser energeticamente desfavorável, quando comparada à respiração mitocondrial. O chamado efeito Warburg acontece em diversos tipos de células cancerosas, mas não todas. Está adaptação metabólica está principalmente ligada à habilidade da glicólise, através de vias intermediárias, gerar moléculas necessárias para proliferação 
rápida, como nucleotídeos, aminoácidos e lipídeos (Giampazolias and Tait, 2015; Vyas et al., 2016).

O melanoma metastático possui os maiores índices de mortalidade entre os diversos tipos de cânceres de pele, e seu tratamento é um grande desafio clínico. O melanoma provém do acúmulo de mutações malignas nos melanócitos (Keller et al., 2017). Um dos eventos oncogênicos mais bem estudados em melanoma é a mutação do BRAF, uma proteína quinase que age na cascata de quinases de ativação por mitógenos RAS-RAF-MEK-ERK (também conhecida como via das MAPK) (Pylayeva-Gupta et al., 2011). A mutação mais comum do BRAF encontrada no melanoma é a substituição pontual no resíduo 600 de uma valina para um ácido glutâmico (BRAFV600E). Melanomas com BRAF selvagem, geralmente apresentam mutações nas proteínas upstream da via das MAPK (Hodis et al., 2012).

A preferência pelo metabolismo glicolítico em células de melanoma é bem documentado, e a importância da mitocôndria para estas células é controversa, porém ela permanece funcional na maioria dos casos. Um dos determinantes moleculares para a capacidade de produção energética da mitocôndria é a via regulada por MITF-PGC1 $\alpha$ (Abildgaard and Guldberg, 2015). Esse eixo geralmente se encontra suprimido em células de melanoma devido à atividade aumentada de BRAF. Entretanto, alguns subgrupos de melanomas apresentam alta expressão de $\mathrm{PGC1} 1 \alpha$, o que leva a uma alta na respiração mitocondrial e um potencial aumentado de proteção contra EROS, o que permite que essas células sobrevivam em condições de alto estresse (Haq et al., 2013; Vazquez et al., 2013). MITF é um regulador do desenvolvimento dos melanócitos e é requerido para sobrevivência e diferenciação destas células. Em células de melanoma, MITF pode se encontrar amplificado, estima-se que a alta expressão de MITF provê um mecanismo compensatório para evitar a completa depleção do MITF pela ação do BRAF. Já PGC1 $\alpha$ é o principal regulador da biogênese mitocondrial e sua alta expressão está relacionada com aumento na capacidade fosforilativa da mitocôndria.

A transformação oncogênica também se relaciona com a dinâmica mitocondrial, já que Drp1 é um alvo da fosforilação de ERK1/2. Esta fosforilação da Drp1(S616) está relacionada com ativação da Drp1 e indução da fissão mitocondrial (Kashatus et al., 2015; Serasinghe et $a l ., 2015)$. Esse achado tornou as células tumorais um bom modelo para o estudo da dinâmica mitocondrial, devido às altas taxas de fosforilação da Drp1(S616) essas células geralmente têm mitocôndrias altamente fragmentadas, o que faz com que a observação dos processos de dinâmica mitocondrial seja bem clara. 
Ao mesmo tempo, a Drp1 se mostrou ser requerida para a transformação celular maligna, uma vez que o knockdown de Drp1 torna as células resistentes à transformação maligna mediada por RASG12V (Serasinghe et al., 2015). Além disso, há também evidências de que o knockdown da Drp1 leva a inibição da invasão e migração de células de câncer de mama, sendo que a fissão mitocondrial é essencial para a formação de lamelopódios (Zhao et al., 2013), e também aumenta a taxa de apoptose de células iniciais de tumores cerebrais (Xie et al., 2015). Estes resultados tornam evidente que a regulação da dinâmica mitocondrial é essencial para a transformação maligna de células, mas ainda não se sabe exatamente como este processo regulatório ocorre.

Interessantemente, a miosina-Va também participa de alguns processos tumorigênicos. Como já dito anteriormente a miosina-Va é altamente expressa em células de melanoma e requerida para manifestação de propriedades malignas deste tipo de câncer (Alves et al., 2013). Além disso miosina-Va é um alvo de MITF (Alves et al., 2017). Tendo isso em vista a grande importância que o citoesqueleto e os motores moleculares têm em relação ao metabolismo e à dinâmica mitocondrial, nós decidimos investigar a relação da miosina-Va com a dinâmica mitocondrial em células de melanoma metastático humano que contêm a mutação BRAFV600E. 


\section{Objetivos}

\subsection{Objetivo Geral}

Investigar o papel da miosina-Va na manutenção da integridade estrutural e funcional da mitocôndria, assim como seu papel na dinâmica mitocondrial.

\subsection{Objetivos Específicos}

1. Investigar a presença de miosina-Va na fração mitocondrial e a ocorrência de interação direta entre miosina-Va e mitocôndrias.

2. Determinar o requerimento da miosina-Va para manutenção da morfologia e função mitocondrial.

3. Analisar a participação da miosina-Va na dinâmica mitocondrial e identificar proteínas parceiras da miosina-Va que atuem na regulação dos processos de dinâmica mitocondrial.

4. Analisar a consequência funcional da redução ou perda de função da miosina-Va em propriedades tumorigênicas das células de melanoma A375. 


\section{Metodologia}

\subsection{Cultivo celular}

Linhagens celulares: A-375 (CRL-161979 - ATCC, Manassas, VA, EUA); HEK-293T (CRL-3216 ${ }^{\mathrm{TM}}$ - ATCC) - linhagem estabelecida a partir de células embrionárias renais humanas transformada por adenovírus tipo 5; U2OS (HTB-96 ${ }^{\mathrm{TM}}$ - ATCC) - linhagem de osteosarcoma. As linhagens A375, HEK-293T e U2OS foram cultivadas em meio Dulbecco's Modified Eagle's Medium (DMEM - Thermo Fisher Scientific, Waltham, MA, EUA) suplementado com 10\% (v/v) de soro bovino fetal (SFB - Thermo Fisher Scientific) inativado, e com $100 \mathrm{mg} / \mathrm{ml}$ penicilina/estreptomicina (Sigma-Aldrich, St Louis, MO, EUA). Todas as células foram mantidas a $37^{\circ} \mathrm{C} \mathrm{em}$ atmosfera úmida contendo $5 \%$ de $\mathrm{CO}_{2}$. As células foram tripsinizadas para experimentos e manutenção com 0,25\% tripsina e 0,025\% EDTA (Sigma-Aldrich).

\subsection{Produção de partículas lentivirais e transdução das linhagens celulares}

Para a produção lentiviral, as HEK-293T foram plaqueadas em placas de 6 poços, e transfectadas com Polietilenimina (PEI - Sigma-Aldrich) em meio Opti-MEM (Thermo Fisher Scientific), com os seguintes plasmídeos: $10 \mu \mathrm{g}$ of pLKO.1 (Sigma-Aldrich) contendo as sequências dos shRNAs; $3,5 \mu \mathrm{g}$ pVSV-G e 6,5 $\mu \mathrm{g} \mathrm{p} \Delta 8.9$. Depois de 16 horas, o meio da transfecção foi trocado para DMEM suplementado com 30\% de SFB. Após 48 e 72 horas o sobrenadante viral foi coletado, filtrado por uma membrana de $0,22 \mu \mathrm{m}$ e adicionado às células de interesse para transdução viral. Depois de 48 horas, o meio de cultura das células transduzidas foi trocado para o meio de cultivo normal (DMEM 10\% SFB), contendo $1 \mu \mathrm{g} / \mathrm{ml}$ de puromicina (Sigma-Aldrich) para a seleção das células transduzidas. As sequências dos shRNAs utilizados são apresentadas na Tabela 1.

Tabela 1. Sequências dos shRNAs utilizados para o silenciamento do gene da MYO5A.

\begin{tabular}{|l|l|l|}
\hline & Nome & Sequência \\
\hline TRCN00000594 & shMVa1 & CCGGGCTCTCTAACACATGCCGATTCTCG \\
\hline 88 & & AGAATCGGCATGTGTTAGAGAGCTTTTTG \\
& & \\
\hline
\end{tabular}




\begin{tabular}{|l|l|l|}
\hline TRCN00000594 & shMVa2 & CCGGCGGATTTGAAACATTTGAGATCTCG \\
\hline 90 & & AGATCTCAAATGTTTCAAATCCGTTTTTG \\
\hline
\end{tabular}

\subsection{CRISPR Nocautes}

Um pool de células nocaute $(\mathrm{KO})$ contra o gene da $M Y O 5 A$ foram gerados através da metodologia CRISPR pela empresa Synthego Corporation (Redwood City, CA, EUA), utilizando a sequência CGAGGAGCTTGATGTCCGCA como guia. Para obtenção de clones únicos, o pool de células foi plaqueado em placas de 96 poços a uma média de 0,5 células/poço e deixado crescer até que um único clone discreto pudesse ser visto no poço. Poços com colônias únicas foram tripsinizados e cultivados como culturas padrão. Assim que células suficientes estivessem disponíveis, as células foram coletadas e submetidas ao sequenciamento Sanger (sequência do primer: GCTTTTTGCTCATTCCAATTTATACTTACA). Os resultados do sequenciamento Sanger foram analisados usando a ferramenta ICE Analysis (v2) (Synthego Performance Analysis, ICE Analysis., 2019)Synthego Corporation). Os clones com 100\% de eficiência $\mathrm{KO}$ foram escolhidos para ensaios posteriores.

\subsection{Imunodetecção de proteínas - Western Blot}

As células foram plaqueadas em placas de 6 poços e no dia seguinte foram lavadas com tampão fosfato-salino (PBS 1X) e em seguida lisadas com tampão RIPA (20 mM Tris, pH 7.5; 150 mM NaCl; 1mM EDTA; 1 mM EGTA; $1 \%$ (v/v) NP-40; $1 \%$ deoxicolato de sódio, diluição 1:100 de Halt ${ }^{\mathrm{TM}}$ Protease Inhibitor Cocktail, EDTA-free - Thermo Fisher Scientinfic). Os lisados celulares foram centrifugados a $15000 \times \mathrm{g}$ a $4^{\circ} \mathrm{C}$ por $15 \mathrm{~min}$, e o sobrenadante foi recolhido e submetido à quantificação de proteína utilizando o kit Pierce BCA assay (Thermo Fisher Scientific). Quantidades iguais de lisados (aproximadamente $20 \mu \mathrm{g}$ de proteína) foram submetidos à eletroforese SDS-PAGE utilizando pre-cast 4-15\% Mini-PROTEAN® TGX gels (Bio-Rad, Hercules, CA, EUA). Em seguida, as proteínas foram transferidas para uma membrana de fluoreto de polivinilideno (PVDF) (GE Life Sciences, Buckinghamshire, Inglaterra), utilizando tampão de transferência. Após a transferência, as membranas foram incubadas em solução de bloqueio (5\% de leite em pó desnatado (Molico, São Paulo, Brasil) em TBS-T (Tris HCl 50mM pH8,0; NaCl 150mM, e Tween-20 0,05\% (v/v)), durante 1 hora. E 
então, a membrana foi incubada com o anticorpo primário apropriado por 1 hora a temperatura ambiente, ou $16 \mathrm{~h} \mathrm{a} 4^{\circ} \mathrm{C}$. Após esse período, a membrana foi incubada por mais 1 horas com anticorpo secundário conjugado com peroxidase. Para a visualização das bandas de proteínas, a membrana foi incubada com soluções caseiras de revelação (ECL - Enhanced chemiluminescence), solução I (0,11M Tris/HCL pH 8,5; 2,78mM Luminol (3aminophthalhydrazide - Sigma-Aldrich); 0,44mM ácido p-cumárico (Sigma-Aldrich); 98,4\% $\left.\mathrm{dH}_{2} 0\right)$ e solução II $\left(0,02 \% \mathrm{H}_{2} \mathrm{O}_{2} ; 0,1 \mathrm{M}\right.$ Tris/HCL $\left.\mathrm{pH} 8,5 ; 89,9 \% \mathrm{dH}_{2} \mathrm{O}\right)$ na proporção de $1: 1$ por 1 minuto e exposta para captura da imagem utilizando o sistema Image Quant (GE Life Sciences).

\subsection{Purificação de DNA, RNA e qRT-PCR}

O DNA genômico (gDNA) foi extraído usando o kit ReliaPrep ${ }^{\mathrm{TM}}$ gDNA Tissue Miniprep System (Promega, Madison, WI, EUA) de acordo com as especificações do fabricante. O gDNA foi amplificado usando primers de acordo com um método previamente descrito (Phillips et al., 2014). As sequências analisadas estão na Tabela 2. A quantificação relativa da expressão do mtDNA foi realizada usando o método $2^{-\Delta \Delta C t}$, e normalizada com o DNA nuclear (nDNA).

O RNA total foi extraído das células usando o reagente TRIZOL (Invitrogen, Carlsbad, CA, EUA) de acordo com as especificações do fabricante. Os pellets de RNA foram suspensos em água DEPC e as amostras quantificadas a 260/280 nm em espectrofotômetro (NanoVue GE Life Sciences, Buckinghamshire, Inglaterra).

Para a RT-PCR quantitativa, todas as amostras de RNA $(1 \mu \mathrm{g})$ foram convertidas em cDNA usando o kit de transcrição reversa de cDNA de alta capacidade (Applied Biosystems, Foster City, CA, EUA). A reação foi incubada a $25^{\circ} \mathrm{C}$ por 5 minutos, $42^{\circ} \mathrm{C}$ por 30 minutos e a transcriptase reversa foi inativada por aquecimento a $85^{\circ} \mathrm{C}$ por 5 minutos. Para amplificações, o reagente GoTaq® RT-PCR Systems (Promega) foi usado em reações com um volume final de $12 \mu \mathrm{l}$ contendo $6 \mu \mathrm{l}$ de GoTaq Mix, $2 \mu \mathrm{l}$ de uma mistura de primer senso e antisenso (400 nM de cada primer na reação) e $4 \mu \mathrm{l}$ de cDNA (150 ng). As reações e análises de amplificação foram efetuadas utilizando o equipamento ABI PRISM 7500 Sequence Detection System (Applied Biosystems) utilizando o software ABI 7500 Real-Time PCR SDS 1.2 (Applied Biosystems). A quantificação relativa da expressão de mRNA foi feita usando o método $2^{-\Delta \Delta C t}$. Os primers para os genes analisados foram projetados flanqueando as regiões do íntron para evitar a amplificação de produtos indesejados. Os genes GAPDH e TBP foram usados como 
genes de referência. As sequências dos iniciadores são apresentadas na tabela abaixo (Tabela 2). Os dados da PCR em tempo real foram analisados pelo teste t não pareado, com $P<0,05$ considerado estatisticamente significativo.

Tabela 2. Sequências dos primers utilizados para qRT-PCR.

\begin{tabular}{|c|c|}
\hline Gene & Sequência \\
\hline Senso Miosina-Va & 5'-ССТТТСААСССАТСТТССССТ-3' \\
\hline Antisenso Miosina-Va & 5'-TTGCCTGGACATCACTTTCA-3' \\
\hline Senso DRP1 & 5'- GATGCCATAGTTGAAGTGGTGAC -3' \\
\hline Antisenso DRP1 & 5'- CCACAAGCATCAGCAAAGTCTGG-3' \\
\hline Senso OPA1 & 5'-GTGGTTGGAGATCAGAGTGCTG-3' \\
\hline Antisenso OPA1 & 5'-GAGGACCTTCACTCAGAGTCAC-3' \\
\hline Senso FIS1 & 5'-CAAGGAACTGGAGCGGCTCATT-3' \\
\hline Antisenso FIS1 & 5'-GGACACAGCAAGTCCGATGAGT-3' \\
\hline Senso MFN1 & 5'-GGTGAATGAGCGGCTTTCCAAG-3' \\
\hline Antisenso MFN1 & 5'-TCСТCCACCAAGAAATGCAGGC-3' \\
\hline Senso MFN2 & 5'-ATTGCAGAGGCGGTTCGACTCA-3' \\
\hline Antisenso MFN2 & 5'-TTCAGTCGGTCTTGCCGCTCTT-3' \\
\hline Senso PGC1 $\alpha$ & 5'-AATTGAAGAGCGCCGTGT-3' \\
\hline Antisenso PGC1 $\alpha$ & 5'-AACCATAGCTGTCTCCATC-3' \\
\hline Senso GAPDH & 5'-GTCTCCTCTGACTTCAACAGCG-3' \\
\hline Antisenso GAPDH & 5'-ACCACCCTGTTGCTGTAGCCAA-3' \\
\hline Senso nDNA $(\beta 2 \mathrm{M})$ & 5'- GCTGGGTAGCTCTAAACAATGTATTCA-3 \\
\hline Antisenso nDNA $(\beta 2 \mathrm{M})$ & 5'- CCATGTACTAACAAATGTCTAAAATGGT-3' \\
\hline Senso mtDNA (ND4) & 5'- CTGTTCCCCAACCTTTTCCT-3 \\
\hline
\end{tabular}




\section{Antisenso mtDNA (ND4) 5'- CCATGATTGTGAGGGGTAGG-3'}

\subsection{Imunocitoquímica}

As células foram plaqueadas em lamínulas redondas de $13 \mathrm{~mm}$ em placas de 24 poços, em meio apropriado. Depois de 18 a 24 horas, as células foram lavadas com PBS e fixadas com $2 \%$ de paraformaldeído (Sigma-Aldrich) (m/v) em PBS pH 7,4, por 10 minutos. Logo em seguida, as células foram permeabilizadas com 0,3\% (v/v) Triton X-100 (Sigma-Aldrich), bloqueadas com $10 \mathrm{mM}$ de glicina (Sigma-Aldrich), e finalmente bloqueadas com $2 \%(\mathrm{~m} / \mathrm{v})$ BSA (Sigma-Aldrich) em PBS em temperatura ambiente por 1 hora. Em seguida, as células foram incubadas com o anticorpo primário apropriado por $1 \mathrm{~h}$ em temperatura ambiente. As células foram então incubadas por 1h em temperatura ambiente com os anticorpos secundários apropriados. Entre cada etapa, as células foram lavadas 3 vezes, de 5 min cada, com PBS. As lamínulas foram montadas em lâminas utilizando ProLong® Diamond Antifade Mountant medium with DAPI (P36962 - Thermo Fisher Scientific).

\subsection{Anticorpos utilizados}

Rabbit polyclonal antibody, affinity purified, recognizing myosin $\mathrm{Va}$;

Rat polyclonal antibody, affinity purified, recognizing myosin Va; TOMM20 [EPR15581] - mitochondrial marker (Abcam: ab186734) (Rabbit);

Cytochrome C - Mouse monoclonal antibody (BD Pharmingen: \#556432); phosphoDRP1(S616) - (Cell Signaling: \#3455) Rabbit mAb;

DRP1 D6C7 (Cell Signaling: \#8570);

MFN1 D6E2S (Cell Signaling: \#14739) Rabbit mAb;

MFN2 D2D10 (Cell Signaling: \#9482) Rabbit mAb;

Alexa Fluor 594 Phalloidin (ThermoFisher Scientific: \# A12381);

p44/42 MAPK (Erk1/2) (Cell Signaling: \#137f5) Rabbit mAb; phospho p44/42 MAPK (Erk1/2) (Thr202/Tyr204) (Cell Signaling: \#137f5) Mouse mAb.

\subsection{Transfecção de proteínas fluorescentes}

Para expressão de proteínas fluorescentes, as células foram plaqueadas em lamínulas redondas de 13 mm de diâmetro (Knittel, Braunschweig, Alemanha) em placas de 24 poços. 
No dia seguinte, as células foram transfectadas com os plasmídeos de interesse utilizando Lipofectamine ${ }^{\circledR} 2000$ (Thermo Fisher Scientific), de acordo com as recomendações do fabricante, em um volume final de $250 \mu \mathrm{L}$ de meio Opti-MEM (Thermo Fisher Scientific). Depois de $48 \mathrm{~h}$ de incubação, as células foram lavadas com PBS e fixadas $2 \%(\mathrm{v} / \mathrm{v})$ de paraformaldeído $\mathrm{pH} \mathrm{7,4}$ por $10 \mathrm{~min}$, e processadas para imunofluorescência como descrito anteriormente.

Para as células utilizadas em experimentos de live-imaging, após 4 horas de incubação das células com os complexos de Lipofectamina-DNA, as células foram tripsinizadas e passadas para câmeras de 8-poços \#1.5 ou para placas de 35 mm \#1.5 (Cellvis, Mountain, CA. EUA) próprias para aquisição de imagens. Após 24h, as células foram coradas com MitoTracker Deep Red (50 nM - Thermo Fisher) por 30min, lavadas com PBS e colocadas em meio FluoroBrite (Thermo Fisher Scientific) para aquisição de imagens.

Os seguintes plasmídeos foram utilizados: mCherry-DRP1 (Plasmídeo \#49152 Addgene, Watertown, MA, EUA); pDsRed-Mito (Plasmídeo \#55838 - AddGene); full length mito-Spire1 (myc-SpireFL) (Manor et al., 2015); full length mito-Spire com tag fluorescente (mStraberry-mitoSpire1) (Straub et al., 2020); mouse myosin-Va-Full Length (MVaFLGFP)(Wu, X. S. et al., 2002); chicken brain globular tail of myosin-Va (GT-GFP - resíduos 1423-1830); chicken brain medial tail (parcial) e globular tail of myosin-Va (MGT-GFP resíduos 1377-1830); chicken brain full tail of myosin-Va (FT-GFP - resíduos 899 - 1830).

\subsection{Silenciamento com siRNAs}

Para o silenciamento com siRNAs, as células foram plaqueadas ou em placas de 6 poços ou em placas de 24 poços a uma confluência de aproximadamente $70 \%$. No dia seguinte, as células foram transfectadas com os siRNAs de interesse utilizando Lipofectamine ${ }^{\circledR} 2000$, de acordo com as recomendações do fabricante, em um volume final de $250 \mu \mathrm{L}$ de meio OptiMEM. Após 4 horas de incubação com os complexos de Lipofectamina-siRNAs, o meio cultivo foi trocado para DMEM com 10\% SFB, e incubadas por 48 horas. Para os experimentos moleculares, após o período de 48 horas as células foram lavadas com PBS e processadas para extração de RNA como descrito na seção pertinente.

Para as células utilizadas em experimentos de live-imaging, as células foram transfectadas com um plasmídeo contendo apenas GFP em um ratio de 2:1 (siRNA:GFP) com o objetivo de indicar as células transfectadas. Após 4 horas de incubação das células com os complexos de Lipofectamina-DNA, as células foram tripsinizadas e passadas para placas de 35 
mm \#1.5 próprias para aquisição de imagens. Após 48h, as células foram coradas com MitoTracker Deep Red (50 nM) por 30min, lavadas com PBS, e colocadas em meio FluoroBrite para aquisição de imagens.

\subsection{Microscopia confocal e SR-SIM}

Para aquisição de imagens de microscopia confocal a laser utilizamos os sistemas Leica SP5 ou Leica SP8 (Leica, Wetzlar, Alemanha), com uma objetiva de imersão em óleo 63x 1.4N.

Quando indicado utilizamos Plan-Apochromat ×63/1.4 NA objetivas de imersão à óleo em um microscópio confocal Airyscan Zeiss 880 LSM invertido (Carl Zeiss Microimaging, Oberkochen, Alemanha) com controle de temperatura e umidade, provendo $37{ }^{\circ} \mathrm{C}, 5 \% \mathrm{CO}_{2} \mathrm{e}$ umidade para experimentos com células vivas. As imagens adquiridas com o Airyscan Zeiss 880 LSM foram “Airyscan Processed" usando as configurações de autofiltro 2D-SR em Zen Blue (Carl Zeiss Microimaging).

No caso das imagens adquiridas através da microscopia de iluminação estruturada (SRSIM), as células foram analisadas em um microscópio ELYRA S.1 (Carl Zeiss Microimaging), equipado com um laser $488 \mathrm{~nm}(100 \mathrm{~mW})$, um laser $561 \mathrm{~nm}(100 \mathrm{~mW})$ e um Andor EM-CCD câmera (iXon DU 885). Pilhas Z finas $(0,1 \mathrm{~mm})$ de quadros de imagem de alta resolução foram coletadas em 5 rotações, utilizando uma objetiva alfa Plan-Apochromat 63 × / 1 - 46 óleo DIC M27ELYRA. A aquisição, reconstrução e alinhamento das imagens para microscopia de iluminação estruturada foram realizados usando o software Zeiss ZEN 2012 SP1 (edição preta, versão 8.1.5.484).

\subsection{Microscopia eletrônica de transmissão (TEM)}

As células foram cultivadas em uma placa de 6 poços em meio de células apropriado como descrito acima. Após 18-24h as células foram fixadas com $2 \%$ de glutaraldeído, $2 \%$ de

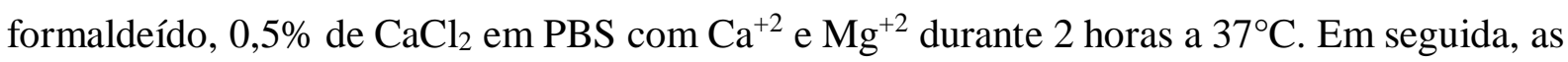
células foram lavadas com tampão cacodilato $0,1 \mathrm{M}(\mathrm{pH} 7,4)$ durante 1 hora a $4^{\circ} \mathrm{C}$. As células fixadas foram pós-fixadas com $1 \% \mathrm{OsO}_{4}$ por 2 horas a $4^{\circ} \mathrm{C}$, lavadas com $\mathrm{dH}_{2} \mathrm{O}$ e desidratadas em uma série graduada de etanol (30\% a 100\%), infiltradas com óxido de propileno e incorporadas na resina Embed 812, polimerizado por 72 horas a $60^{\circ} \mathrm{C}$. Cortes ultrafinos foram corados com acetato de uranila e citrato de chumbo por 10min e examinados em microscópio eletrônico (JEM-100 CXII - JEOL, Tóquio, Japão). Um experimento único com dois graus foi 
analisado.

\subsection{Processamento de imagens}

Todas as imagens foram pós-processadas e analisadas usando o software Imaris (BITPLANE) e Fiji (Schindelin et al., 2012). Todas as imagens mostradas são de planos focais únicos, a menos que seja indicado o contrário. Todas as imagens comparadas foram adquiridas com os mesmos parâmetros. Para fins de visualização, a cor, o brilho e o contraste, quando necessário, foram modificados, sempre mantendo as proporções equivalentes. Os arquivos brutos foram usados para todas as quantificações.

Quando indicado, a colocalização foi analisada no Icy-Bioimage com o plugin Colocalization Studio (Lagache et al., 2015) usado para calcular os coeficientes de Pearson, além disso um dos canais usados para colocalização foi girado $180^{\circ}$ e reenviado para a análise sendo usada como controle negativo (colocalização aleatória). Todas as análises estatísticas e gráficos foram gerados usando o software GraphPad Prism 7 (GraphPad Softaware, San Diego, CA, EUA).

\subsection{Ensaio de proliferação}

$5 \times 10^{3}$ células foram plaqueadas em placas de 96 poços, e as análises foram realizadas nos tempos de $24 \mathrm{~h}, 48 \mathrm{~h}, 72 \mathrm{~h}, 96 \mathrm{~h}$ e $120 \mathrm{~h}$. Para o ensaio o meio foi retirado e os poços foram lavados com $200 \mu \mathrm{L}$ PBS 1X, seguindo-se fixação das células com $100 \mu \mathrm{L}$ etanol $70 \%$ (Labsynth, Diadema, SP, Brasil) por 10 minutos, e posteriormente adição de $40 \mu \mathrm{L}$ de 0,5\% cristal violeta (Labsynth) por 30 minutos. Após esse período, os poços foram lavados por cinco vezes com $200 \mu \mathrm{L}$ de água ultrapura autoclavada e foi adicionado $100 \mu \mathrm{L}$ de ácido acético $10 \%$ (Sigma-Aldrich) para ocasionar a lise celular. As células ficaram incubadas por 30 minutos e a absorbância $(540 \mathrm{~nm})$ foi analisada utilizando o leitor de ELISA (PowerWave, microplate scanning spectrophotometer-Biotech Incorporation).

\subsection{Ensaio de migração}

As células foram plaqueadas em placas de 96 poços $\left(10^{4}\right.$ células/poço $)$ e cultivadas até atingirem 95\% de confluência. Utilizando uma ponteira de plástico estéril, foi feito uma ranhura (remoção das células nessa área do risco) no centro de cada poço, seguida de duas lavagens com PBS e adição de meio DMEM com soro fetal bovino reduzido a 1\%, a fim de criar ambiente 
com escassez de nutrientes e propício a migração celular. As células foram mantidas em estufa úmida à temperatura de $37^{\circ} \mathrm{C}$ e atmosfera de $5 \%$ de $\mathrm{CO}_{2}$ e fotografadas logo após a realização da ranhura e $24 \mathrm{~h}$ e $48 \mathrm{~h}$ depois.

\subsection{Ensaio clonogênico}

$3 \times 10^{2}$ células foram transferidas para placas de 6 poços e mantidas por 10 dias em uma incubadora de células sob $95 \%$ de ar e $5 \%$ de $\mathrm{CO}_{2}$ a $37^{\circ} \mathrm{C}$. Após esse período, as células foram fixadas com paraformaldeído $4 \%(\mathrm{~m} / \mathrm{v})$ em PBS $(\mathrm{pH} 7,4)$ e coradas com cristal violeta $0,5 \%$ $(\mathrm{m} / \mathrm{v})$ para visualização das colônias. As placas foram fotografadas e o número de colônias contado.

\subsection{Ensaios para detecção de metabólitos}

O ensaio Glucose Uptake-Glo ${ }^{\mathrm{TM}}$ (Promega cat. \# J1341) foi usado para medir a absorção de glicose na cultura de células. Para isso, $2 \times 10^{4}$ células foram plaqueadas em placas de 96 poços no dia anterior ao experimento, e o ensaio foi feito seguindo as recomendações do fabricante.

A secreção de lactato foi medida em meio celular de células em cultura usando o ensaio Lactate-Glo ${ }^{\mathrm{TM}}$ (Promega cat. \# J5021). Para isso, 5 $\times 10^{4}$ células foram semeadas em placas de 24 poços, o meio foi coletado $48 \mathrm{~h}$ após e o ensaio foi feito recomendações do fabricante foram seguidas.

\subsection{Enriquecimento da fração mitocondrial}

Para o enriquecimento da fração mitocondrial, $2 \times 10^{7}$ células foram tripsinizadas, e o pellet de células foi processado utilizando o kit "Mitochondria Isolation for Cultured Cells" (Thermo Fisher Scientific cat. \#89874) de acordo com as recomendações do fabricante. O pellet mitocondrial foi lisado com tampão de amostra 2X, e utilizado para SDS-PAGE e posterior western blot.

\subsection{Consumo de oxigênio e níveis de acidificação extracelular.}

As taxas de consumo de oxigênio (OCRs - oxygen consumption rates) e os níveis de 
acidificação extracelular (ECAR - extracelular acidification rates) foram determinadas em um Seahorse Bioscience Extracellular Flux Analyzer (XF'96) (Agilent Technologies, Santa Clara, CA, EUA). As células foram semeadas em placas Seahorse de 96 poços a 1,5×10 4 células por poço, em DMEM, e deixadas durante a noite. No dia do ensaio, as células foram incubadas em meio OCR (meio Seahorse Base: $10 \mathrm{mM}$ glicose, $100 \mathrm{mM}$ piruvato e $200 \mathrm{mM}$ glutmato) durante 1 hora a $37^{\circ} \mathrm{C}$ sem $\mathrm{CO}_{2}$. As taxas de consumo de oxigênio foram analisados para (a) respiração mitocondrial basal; (b) respiração acoplada (após adição de 1,5 $\mu \mathrm{M}$ de oligomicina que é inibidor de Complexo V ATPase); (c) reserva respiratória (após desacoplar completamente a respiração com $2 \mu \mathrm{M}$ FCCP); e (d) respiração máxima, avaliada pelo bloqueio da cadeia de transferência de elétrons (ETC) com $0,5 \mu \mathrm{M}$ rotenona (inibidor do Complexo I) e $0,5 \mu \mathrm{M}$ antimicina (inibidor do Complexo III). Os níveis de acidificação extracelular foram calculados no meio das células em cultivo em condições basais, e após adição de $10 \mathrm{mM}$ de glicose, $1 \mu \mathrm{M}$ de oligomicina e $50 \mathrm{mM}$ de $2-\mathrm{DG}$.

\subsection{Cromatografia de afinidade da miosina-Va}

Realizado por R. Taranath e M. Stern de acordo com os métodos de Finan, Hartman e Spudich com as seguintes modificações (Finan et al., 2011). Resumidamente, o domínio da cauda globular da miosina-Va provinda de melanócitos de camundongos e contendo algumas das regiões coiled-coil (para auxiliar na dimerização e estabilidade) foi purificada e usada para construir uma coluna de afinidade de acordo com o protocolo descrito anteriormente (Finan et al., 2011). O domínio de ligação de carga da miosina-VI foi usado como comparação e controle interno. O extrato do cérebro de camundongos BL6 de 6-8 semanas de idade foi passado pela coluna e as proteínas foram eluídas com lavagens de solução salina com concentrações crescentes. Proteínas e complexos proteicos que se ligaram mais fortemente à coluna MVa foram eluídos com $\mathrm{KCl} 1 \mathrm{M}$ e analisados usando SDS-PAGE e espectrometria de massa.

\subsection{Confirmação da ligação da mitoSpire1 à miosina-Va}

Os ensaios de ligação direta foram realizados de acordo com (Finan et al., 2011). Resumidamente, uma construção myc-mitoSpire1 sem o domínio KIND N-terminal foi traduzida in vitro utilizando lisados de reticulócitos de coelho. As reações de ligação foram realizadas combinando a proteína myc-mitoSpire1 traduzida com a proteína miosina-Va purificada ou com domínios da cauda da miosina-VI ligados à uma resina de glutationa-agarose. 
A miosina-VI foi usada como um controle para a ligações não específicas. As proteínas que copurificaram com miosina-Va ou miosina-VI foram isoladas e analisadas por western blots. Para detecção da proteína myc-mitoSpire1 um anticorpo anti-myc (2276S - Cell Signaling Technology, Danvers, MA, EUA) foi utilizado.

\subsection{Imunopreciptação de mitoSpire1}

A mitoSpire1 inteira com tag myc e um construto contendo apenas o ÉxonC da mitoSpire 1 também com tag myc (ou vetor pcDNA3.1 (+) vazio) foram transfectados em uma placa de $100 \mathrm{~mm}$ com células HEK293T usando Lipofectamine 2000 de acordo com as recomendações do fabricante. 48 horas após a transfecção, as células foram colhidas e lisadas em tampão RIPA (Thermo Fisher Scientific cat. \#89901) suplementado com coquetel inibidor de protease completo (Roche, Basileia, Suiça) e PMSF $1 \mathrm{mM}$. As células foram lisadas em gelo por 20 min, seguido por centrifugação a 20000 x g por 20 min a $4{ }^{\circ} \mathrm{C}$ para remover os resíduos celulares. Os lisados celulares foram incubados com anticorpo de anti-myc (2276S - Cell Signaling Technology, Danvers, MA, EUA) a $4{ }^{\circ} \mathrm{C}$ durante a noite. Na manhã seguinte, beads de agarose de proteína A/G pré-lavadas (sc-2003 - Santa Cruz Biotechnology, Dallas, TX, EUA) foram adicionadas e incubadas a $4^{\circ} \mathrm{C}$ por 2 horas em uma plataforma giratória. As proteínas ligadas foram lavadas quatro vezes com TBS-T e eluídas com tampão de amostra $1 \times$ SDS. Os eluentes foram então processados para proteômica.

\subsection{Espectometria de massas e análise de dados}

As amostras digeridas foram analisadas em um espectrômetro de massa Q Exactive (Thermo Fisher Scientific). As amostras digeridas foram injetadas diretamente em uma coluna de $30 \mathrm{~cm}, 75 \mu \mathrm{m}$ ID empacotada com resina BEH 1,7 $\mu \mathrm{m}$ C18 (Waters Corporation, Milford. MA, EUA). As amostras foram separadas a uma taxa de fluxo de $200 \mathrm{nl} / \mathrm{min}$ em um nLC 1000 (Thermo Fisher Scientific). Os tampões A e B eram ácido fórmico a 0,1\% em água e acetonitrila, respectivamente. As amostras foram incubadas em um gradiente de $5-40 \%$ B ao longo de $110 \mathrm{~min} ; 50 \% \mathrm{~B}$ ao longo de $10 \mathrm{~min} ; 90 \% \mathrm{~B}$ ao longo de outros $10 \mathrm{~min}$ e mantido em 90\% B por 10 min finais de lavagem. A coluna foi reequilibrada com $20 \mu 1$ de tampão A antes da injeção das amostras. Os peptídeos foram eluídos diretamente da ponta da coluna e jogados diretamente no espectrômetro de massa pela aplicação de voltagem de 2,5 kV na parte posterior da coluna. O Q Exactive foi operado em um modo dependente de dados. Varreduras completas 
de espectrometria de massas (EM) foram coletadas (He et al., 2015) no Orbitrap com resolução de $70 \mathrm{~K}$ com uma faixa de massa de 400 a $1800 \mathrm{~m} / \mathrm{ze}$ um alvo AGC de $5 \mathrm{e}^{6}$. Os dez íons mais abundantes por varredura foram selecionados para análise EM/EM com fragmentação de HCD de 25NCE, um alvo AGC de $5 \mathrm{e}^{6}$ e intensidade mínima de $4 \mathrm{e}^{3}$. Os tempos máximos de preenchimento foram definidos em $60 \mathrm{~ms}$ e $120 \mathrm{~ms}$ para varreduras de EM e EM/EM, respectivamente. Foi utilizado o isolamento quadrupolo de $2,0 \mathrm{~m} / \mathrm{z}$, a exclusão dinâmica foi definida para 15 segundos e os estados de carga não atribuídos foram excluídos.

A identificação de proteínas e peptídeos foi feita com Integrated Proteomics Pipeline IP2 (Integrated Proteomics Applications, San Diego, CA, EUA). Espectros de massa em tandem foram extraídos de arquivos brutos usando RawConverter (He et al., 2015) e pesquisados com ProLuCID (Xu et al., 2015) em banco de dados UniProt humano. O espaço de pesquisa incluiu todos os candidatos a peptídeos totalmente trípticos e semitrípticos com no máximo duas clivagens perdidas. A carbamidometilação em cisteína foi contada como uma modificação estática. Os dados foram pesquisados com tolerância de íon precursor de 50 ppm e tolerância de íon de fragmento de $50 \mathrm{ppm}$. Os dados foram filtrados para $10 \mathrm{ppm}$ de tolerância ao íon precursor após a pesquisa. As proteínas identificadas foram filtradas usando DTASelect (Tabb et al., 2002) e utilizando uma estratégia de pesquisa de banco de dados alvo-chamariz para controlar a taxa de descoberta falsa para $1 \%$ no nível da proteína. 


\section{Resultados}

\subsection{A miosina-Va possui uma localização mitocondrial}

Diante do nosso objetivo de estudar a participação da miosina-Va em processos mitocondriais, o nosso primeiro passo foi analisar a colocalização entre a miosina-Va com a rede mitocondrial. Para isso, utilizamos inicialmente as células A375 e fizemos nelas uma imunomarcação utilizando para marcação mitocondrial um anticorpo contra TOM20, uma proteína da MME, e o corante MitoTracker. Concomitantemente, utilizamos para a marcação da miosina-Va dois anticorpos, um produzido em rato (Figura 4A) e outro produzido em coelho (Figura 4B), ambos fabricados em nosso laboratório e já validados previamente (Espindola et al., 1992; Espreafico et al., 1992).

A marcação da miosina-Va é dispersa por todo citoplasma e núcleo da célula, concordante com suas ubíquas funções celulares. E apesar de uma distribuição tão dispersa, é possível observar que uma pequena fração da marcação da miosina-Va possui localização mitocondrial (Figura 4). O coeficiente de colocalização de Pearson's é de 0,2444 \pm 0,008 para a colocalização entre a marcação do anticorpo contra miosina-Va produzido em rato e a proteína TOM20 (Figura 4), e obtivemos resultados muito semelhantes quando analisamos a marcação do anticorpo contra miosina-Va produzido em coelho e o corante MitoTracker (coeficiente de Pearson's, 0,2254 \pm 0,01453 (Figura 9B). A partir de imagens de microscopia de iluminação estruturada (SIM) é possível observar que a miosina-Va se localiza em discretos agrupamentos ao redor da MME (Figura 4E), comprovando o que foi visto utilizando microscopia confocal. Comparamos também a marcação da miosina-Va exógena com a expressão de dois construtos, o primeiro contendo a miosina-Va inteira (MVaFL-GFP), e o segundo contendo a cauda inteira da miosina-Va (MVaFT-GFP), ambos fusionados com o tag GFP. A colocalização do construto da miosina-Va inteira com MitoTracker é levemente menor (coeficiente de Pearson's, 0,2142 $\pm 0,01124)$ quando comparada com a colocalização da miosina-Va endógena (Figura 4C e 4F). Já a colocalização entre o construto da cauda inteira da miosina-Va com MitoTraker é menor ainda quando comparado com a marcação da miosina-Va endógena (coeficiente de Pearson's, 0,1695 $\pm 0,0132$ ) (Figura 4D e 4F). Notamos que há uma maior variabilidade dos coeficientes de Pearson's quando analisamos a expressão exógena da miosina-Va, e acreditamos que é isso é devido à variabilidade de expressão dos construtos, sendo que podem ser mais ou menos abundantes em diferentes células. 

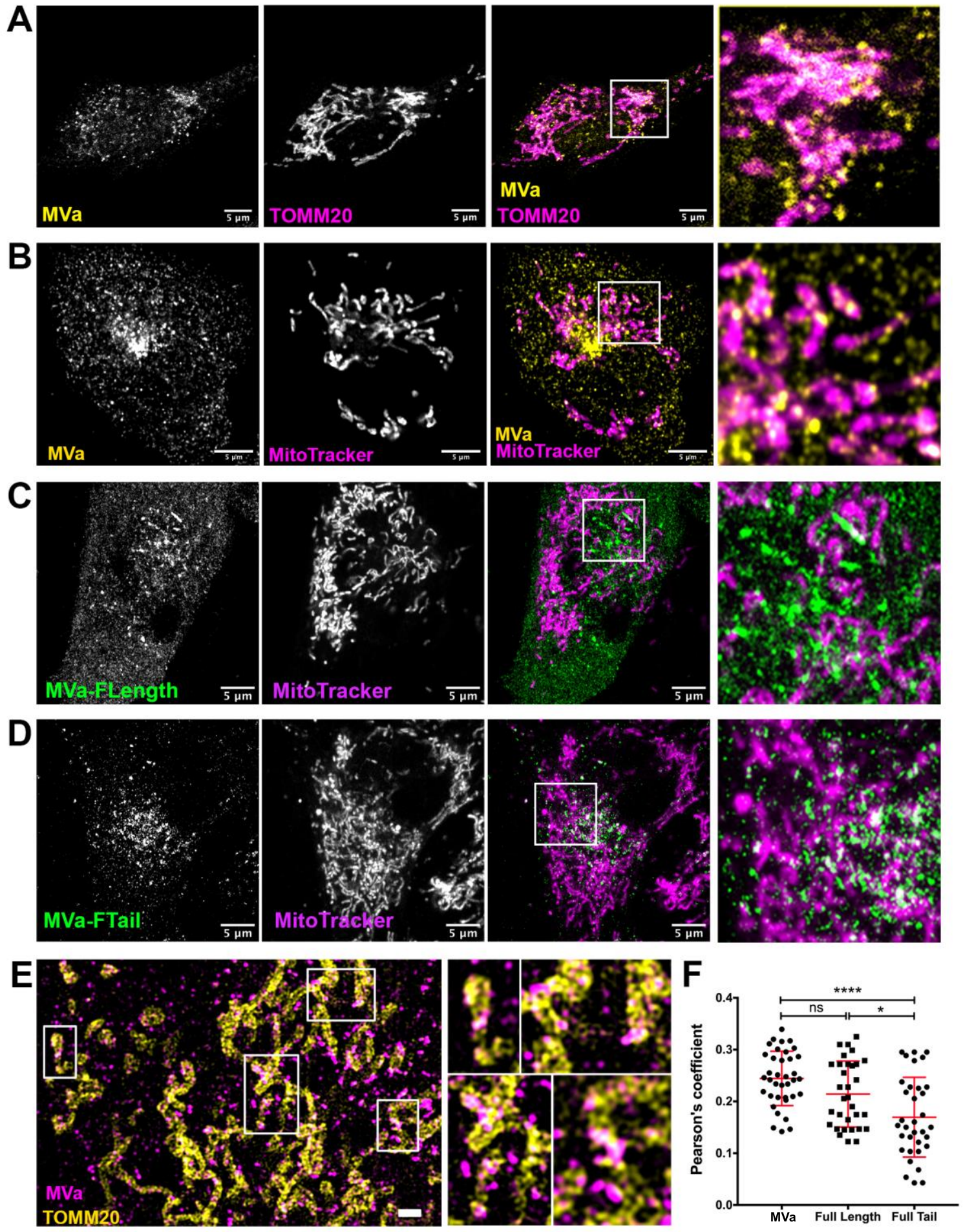

Figura 4. A miosina-Va possui uma localização mitocondrial nas células A375. A. Imagens de microscopia confocal a laser das células A375 mostrando a localização da miosina-Va corada com um anticorpo policlonal de rato (MVa), e a rede mitocondrial rede mitocondrial imunomarcada com anticorpo anti-TOMM20 (coelho). B. Imagens de microscopia de super-resolução Aryscan mostrando a localização da miosina-Va, corada com um anticorpo policlonal de coelho (MVa), e a rede mitocondrial rede mitocondrial corada com MitoTracker DeepRed. Abaixo, imagens de microscopia de super-resolução Aryscan mostrando a localização do construto C. MVa-FLGFP e do construto D. MVa-FT-GFP juntamente com a rede mitocondrial rede mitocondrial corada com MitoTracker DeepRed. E. Imagens de super-resolução utilizando o microscópio ELYRA S.1 (Carl Zeiss Microimaging) de células A375 mostrando a imunolocalização da miosina-Va com um anticorpo policlonal de 
rato, e a rede mitocondrial imunomarcada com anticorpo anti-TOMM20 (coelho). Barra de escala $1 \mu \mathrm{m}$. F. Coeficiente de correlação de Pearson mostrando a colocalização da miosina-Va endógena (MVa) e dos seus construtos em relação à rede mitocondrial. Os dados são média \pm DP. One-way ANOVA **** P <0,0001 (37 células para cada condição, 3 experimentos diferentes).

Para confirmar a interação bioquímica da miosina-Va com a rede mitocondrial, nós fizemos um enriquecimento da fração mitocondrial e verificamos a presença da miosina-Va através de um western blot. Para isso, utilizamos células A375 WT e células A375 nocaute para o gene da miosina-Va, como controle negativo (KO4 e KO5). Observamos que a miosina-Va está presente tanto na fração mitocondrial (M) quanto na fração citoplasmática (C) (Figura 5). Apesar de a fração mitocondrial ainda conter impurezas provindas da fração citosólica, como demonstrado pela marcação da $\gamma$-tubulina (Figura 5), a marcação da miosina-Va na fração mitocondrial é bem evidente e colabora com nossa hipótese de que há uma interação entre a miosina-Va e a rede mitocondrial.

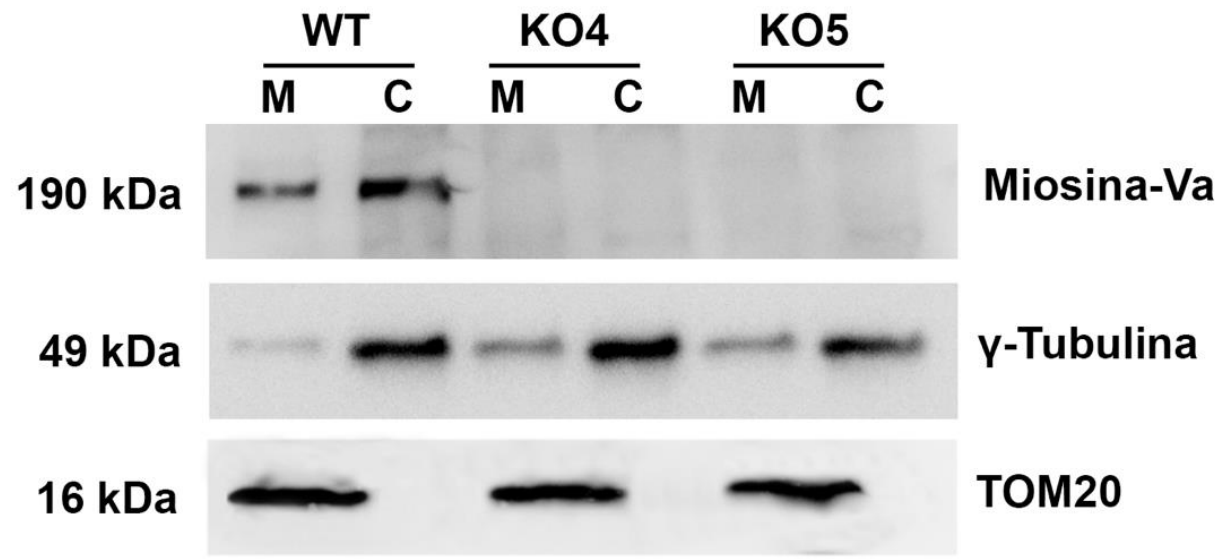

Figura 5. A miosina-Va está presente na fração mitocondrial das células A375. Western blot da fração enriquecida mitocondrial (M) e da fração citosplasmática (C) de células A375 WT, MYO5A KO4 e MYO5A KO5. As células A375 MYO5A KO4 e KO5 foram usadas como controle negativo para presença da miosina-Va. Marcação com os anticorpos anti-miosina-Va (policlonal de coelho anti-cabeça), anti- $\gamma$-Tubulina e anti-TOM20.

\subsection{A miosina-Va é recrutada para mitocôndria pela mitoSpire1}

Ainda interessados em entendermos com quais proteínas a miosina-Va interage na MME, nós realizamos, juntamente com alguns colaboradores, uma cromatografia de afinidade utilizando o domínio da cauda medial globular da miosina-Va (MVa-MGT) (Araujo et al., 2019). As amostras foram analisadas usando espectrometria de massas, e as possíveis proteínas ligantes foram classificadas de acordo com (Finan et al., 2011). Quando nós classificamos as candidatas a proteínas ligantes, Spire1 apareceu como uma das principais interações, tendo uma 
clara especificidade com a miosina-Va, quando comparado com a miosina-VI (Araujo et al., 2019). Outras proteínas interessantes foram encontradas, como a possível interação entre miosina-Va e Dnm1 (Drp1 de mamíferos), a principal proteína envolvida na fissão mitocondrial.

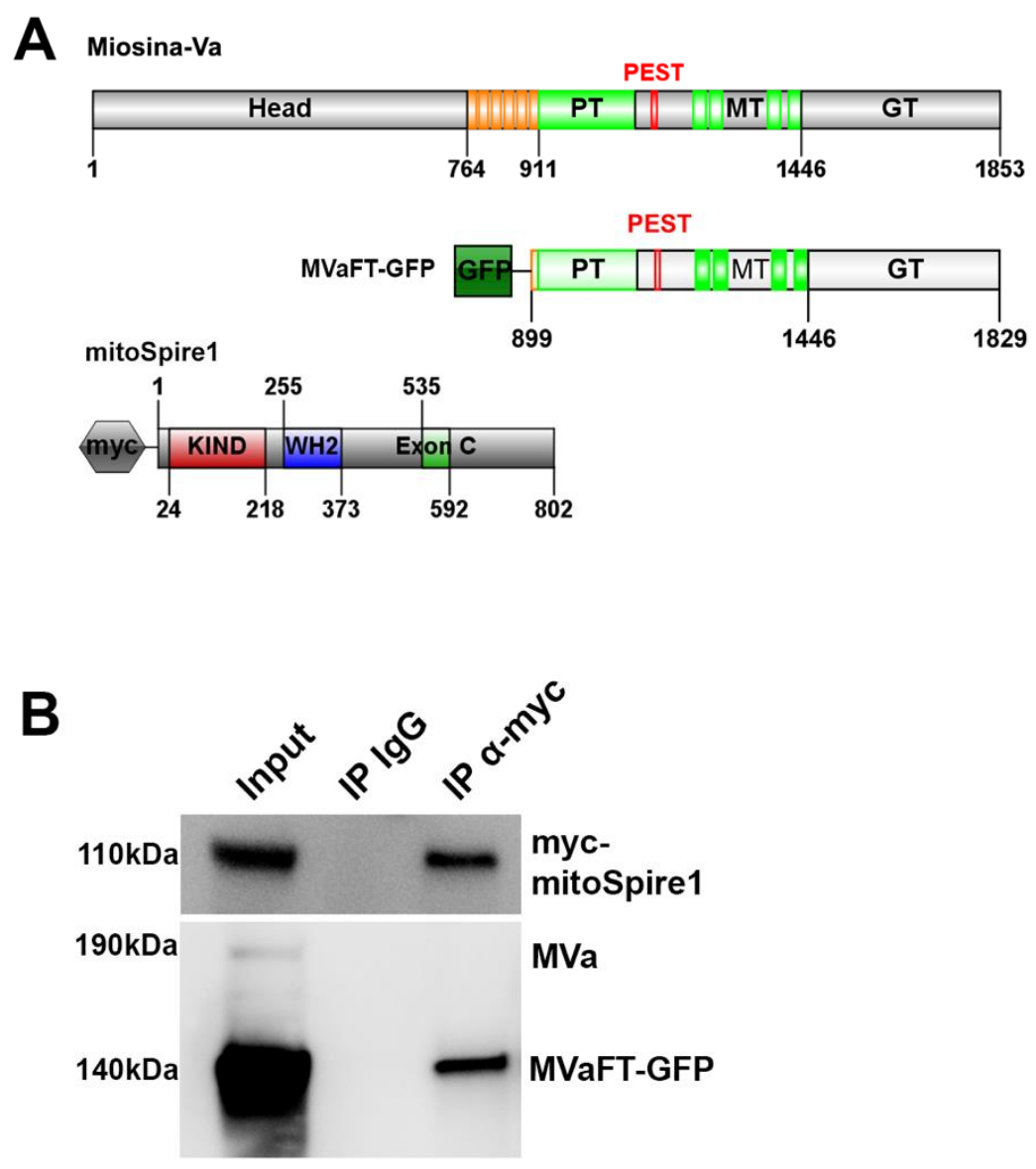

Figura 6. A miosina-Va interage com mitoSpire1. A. Desenho esquemático representativo da estrutura primária da cadeia pesada da miosina-Va. A posição dos subdomínios estruturais é mostrada em: Cabeça (Head); Pescoço (764-911, motivos IQ); PT (cauda proximal); MT (cauda medial); GT (cauda globular); MGT (cauda globular medial). Figura adaptada de Izidoro-Toledo et al., 2013. A estrutura GST-MVa-MGT é mostrada abaixo e foi usada para a interação in vitro com proteínas Spire1. A estrutura dos domínios mitoSpire1 é mostrada com os subdomínios também representados, KIND, WH2 e ÉxonC. Figura adaptada de Manor et al., 2015. O programa IBS está disponível gratuitamente online foi usado para os esquemas (Liu et al., 2015). B. Imunopreciptação (IP) de células HEK-293T co-transfectadas com myc-mitoSpire1 e MVa-FT-GFP. As canaletas são, respectivamente, input, IP IgG (controle negativo utilizando um IgG não reativo) e IP $\alpha$-myc (IP utilizando um anticorpo anti-tag myc responsável por se ligar ao construto myc-mitoSpire1). A IP foi seguida de um Western blot utilizando um anticorpo anti-myc e um anticorpo anti-MVa (policlonal produzido em coelho contra a região da cauda medial da miosina-Va). O anti-MVa foi reativo contra a miosina-Va endógena (190 kDa) e contra o contruto MVa-FT-GFP $(140 \mathrm{kDa})$.

A possível interação entre miosina-Va e Spire1 nos chamou atenção porque Spire1 é uma proteína nucleadora de actina, e possui uma isoforma com um domínio de ligação à MME. 
Essa isoforma é chamada de mitoSpire1, e o seu éxon 13 (chamado aqui de éxon C) é o responsável pela sua localização mitocondrial (Manor et al., 2015). Para validar nossa hipótese de que a miosina-Va interage com a isoforma mitocondrial da Spire1, nós co-expressamos um construto da mitoSpire1 inteira com tag myc juntamente com o construto da cauda interia da miosina-Va com tag GFP (MVa-FT-GFP) em células HEK293T, imunopreciptamos a mitoMitoSpire1 através da sua tag myc, e realizamos um western blot com imunopreciptados obtidos. Os mesmos lisados foram utilizados também em uma imunopreciptação utilizando um IgG não reativo produzido em camundongos, como controle negativo. Nós observamos que há um significante enriquecimento de MVa-FT-GFP nos imunopreciptados de myc-mitoSpire1 (IP $\alpha$-myc), quando comparados com o controle (IP IgG) (Figura 6B).

Para testar a hipótese de que a miosina-Va é recrutada para a MME pela mitoSpire1 por meio da sua interação com o domínio cauda da miosina-Va, nós superexpressamos fragmentos da cauda de miosina-Va com tag GFP juntamente com um construto contendo a mitoSpire1 inteira com tag myc em células A375 (Figura 7). Notamos que todos os construtos de cauda de miosina-Va marcados com GFP usados (Figura 7B - 7E), mas não o GFP sozinho (Figura 7A), localizam-se nas mitocôndrias muito mais fortemente em células que superexpressam mycmitoSpire1, quando comparado com células de controle que não expressão a myc-mitoSpire1. Esses resultados suportam a hipótese de que a mitoSpire1 recruta miosina-Va para a MME a partir da interação com o domínio cauda da miosina-Va.

Indo além, nós também estávamos interessados em compreender o comportamento em células vivas dos construtos da miosina-Va quando recrutados para a MME pela superexpressão da mitoSpire1. Para isso, nós utilizamos células A375 WT e superexpressamos nelas o construto contendo a cauda medial globular da miosina-Va (MGT-GFP) e a mitoSpire1 inteira com tag mStraberry (mStraberry-mitoSpire1FL). A rede mitocondrial dessas células geralmente se torna altamente fragmentada, e seus eventos de dinâmica mitocondrial são escassos (Figura 8 e Filme Suplementar 1), mas sempre que encontramos um evento de fissão mitocondrial temos a presença do construto MGT-GFP (Figura 8, setas brancas). É interessante notar que as regiões de contato entre mitocôndrias e o RE também mostram a presença do construto MGT-GFP, e da mesma forma, o construto mitoSpire1 também está presente nessas regiões (Figura 8, pontas de seta branca). Este experimento foi de grande importância, sendo que nos permitiu a observação da dinâmica da MGT-GFP recrutada para a MME e nos dá um bom indício de interação conjunta da miosina-Va com a mitocôndria e o RE através da mitoSpire1. 

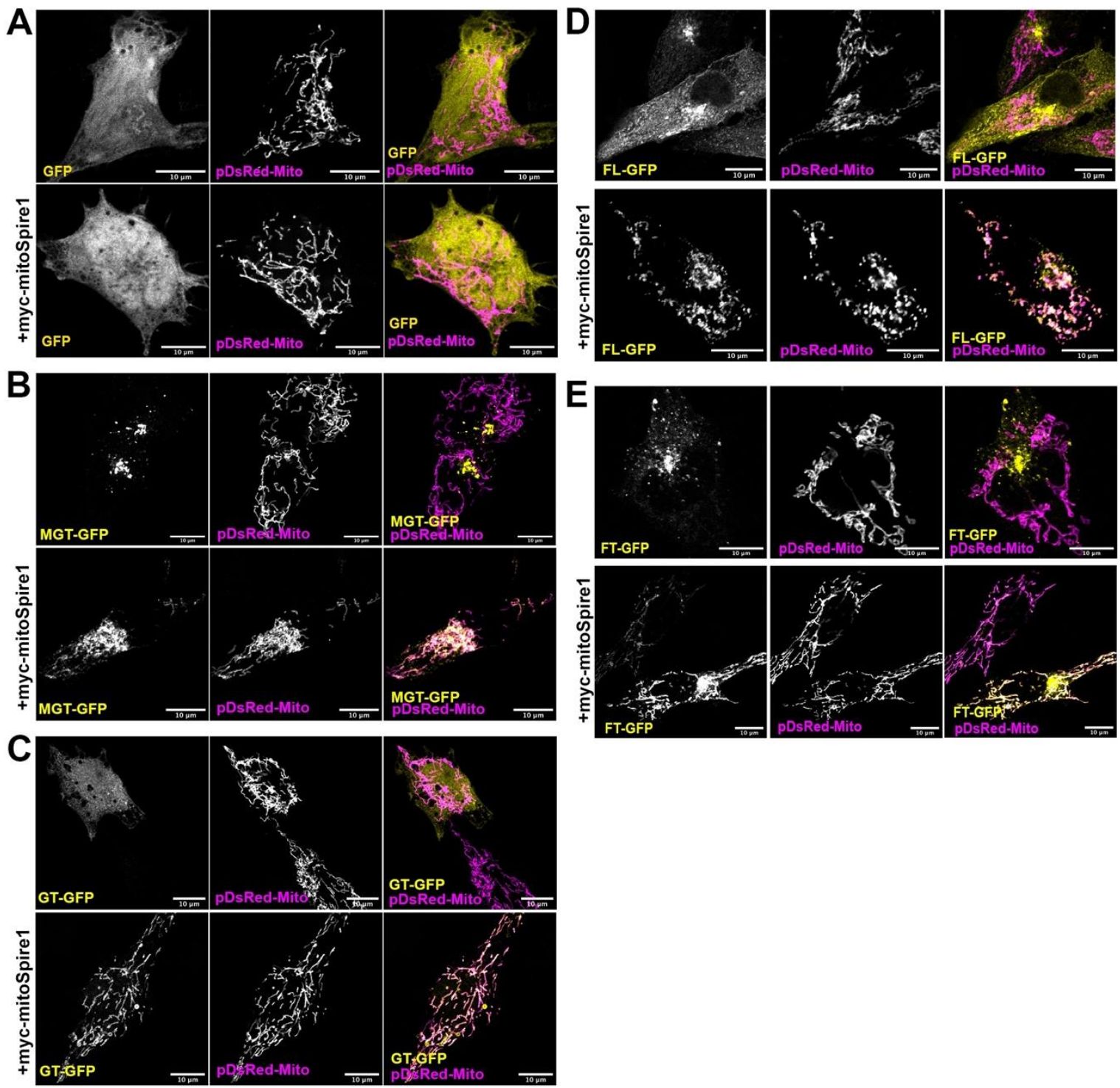

Figura 7. A miosina-Va é recrutada para a rede mitocondrial pela superexpressão da mitoSpire1. A. Expressão do construto GFP vazio; B. e expressão dos construtos MGT-GFP (cauda globular medial da miosinaVA); C. GT-GFP (cauda globular da miosina-Va); D. FL-GFP (miosina-Va inteira); e E. FT-GFP (cauda inteira da miosina-Va) juntamente com pDsRed-Mito (marcador mitocondrial) em células A375. Os painéis superiores são um controle para localização normal dos construtos, e os painéis inferiores mostram a expressão combinada dos mesmos com myc-mitoSpire1 inteira demostrando o recrutamento apenas dos construtos da miosina-Va, e não do GFP vazio, para a rede mitocondrial.

A partir destes dados, nós hipotetizamos que mitoSpire1 recrutaria a miosina-Va para a MME também em condições fisiológicas. Para comprovar isso, superexpressamos um construto contendo a mitoSpire inteira com tag fluorescente (mStraberry-mitoSpire1FL) em células A375, e fizemos uma imunomarcação para miosina-Va com utilizando anticorpo policlonal produzido em coelho, e coramos a rede mitocondrial com MitoTracker. A partir da análise 


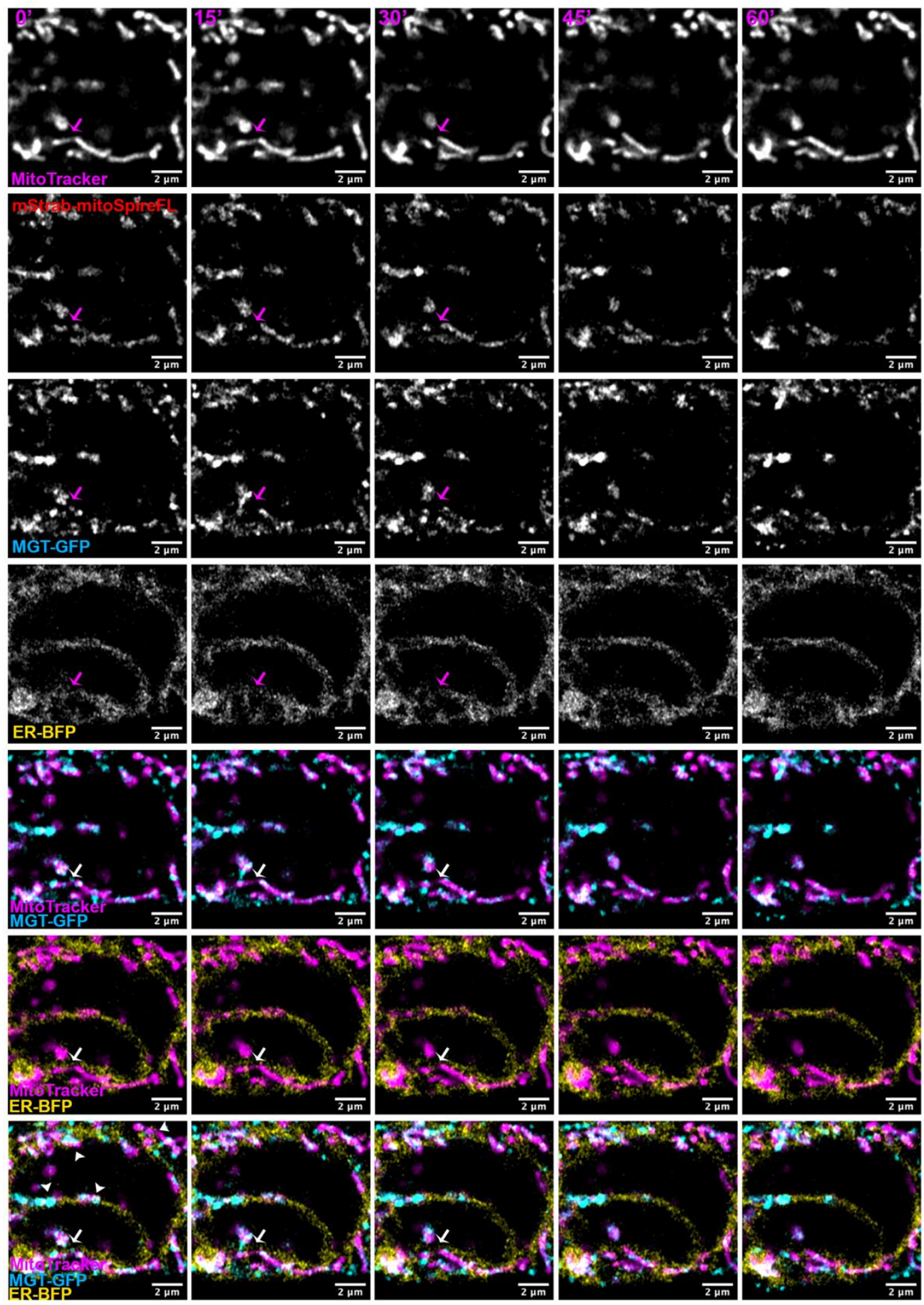

Figura 8. A cauda da miosina-Va é recrutada para a mitocôndria por mitoSpire1 e se acumula nos locais de fissão e nos contatos com o retículo endoplasmático. Imagens de vídeo-microscopia de super-resolução de células A375 coradas com MitoTracker DeepRed (magenta, primeiro painel); além de transfectadas com mitoSpire1 inteira (mStb-mitoSpire1FL, vermelho, segundo painel), com o construto da cauda medial globular da miosina-Va (MGT-GFP, ciano, terceiro painel) e ER-BFP (retículo endoplasmático, amarelo, quarto painel). As setas magentas indicam um local de fissão e a localização de mitoSpire1, MGT-GFP e ER-BFP relacionado a esse local de fissão. Os últimos três painéis mostram as imagens sobrepostas. Setas brancas indicam o mesmo local de fissão das setas magenta acima, e pontos onde MGT-GFP e ER-BFP estão colocalizando na mitocôndria. As pontas da seta branca no último painel mostram outros pontos de colocalização entre MGT-GPF e ER-BFP na mitocôndria. 
destas imagens, obtivemos um aumento significativo no coeficiente de Pearson's para a colocalização da miosina-Va com a rede mitocondrial em células que superexpressam o construto da mitoSpire1 inteira, quando comparado com células não transfectadas (Figura 9A e 9B). É possível notar a mudança no padrão de marcação da miosina-Va na célula superexpressora da mitoSpire1 inteira, e como há um maior acúmulo da miosina-Va em torno da rede mitocondrial (Figura 9A, painéis inferiores).
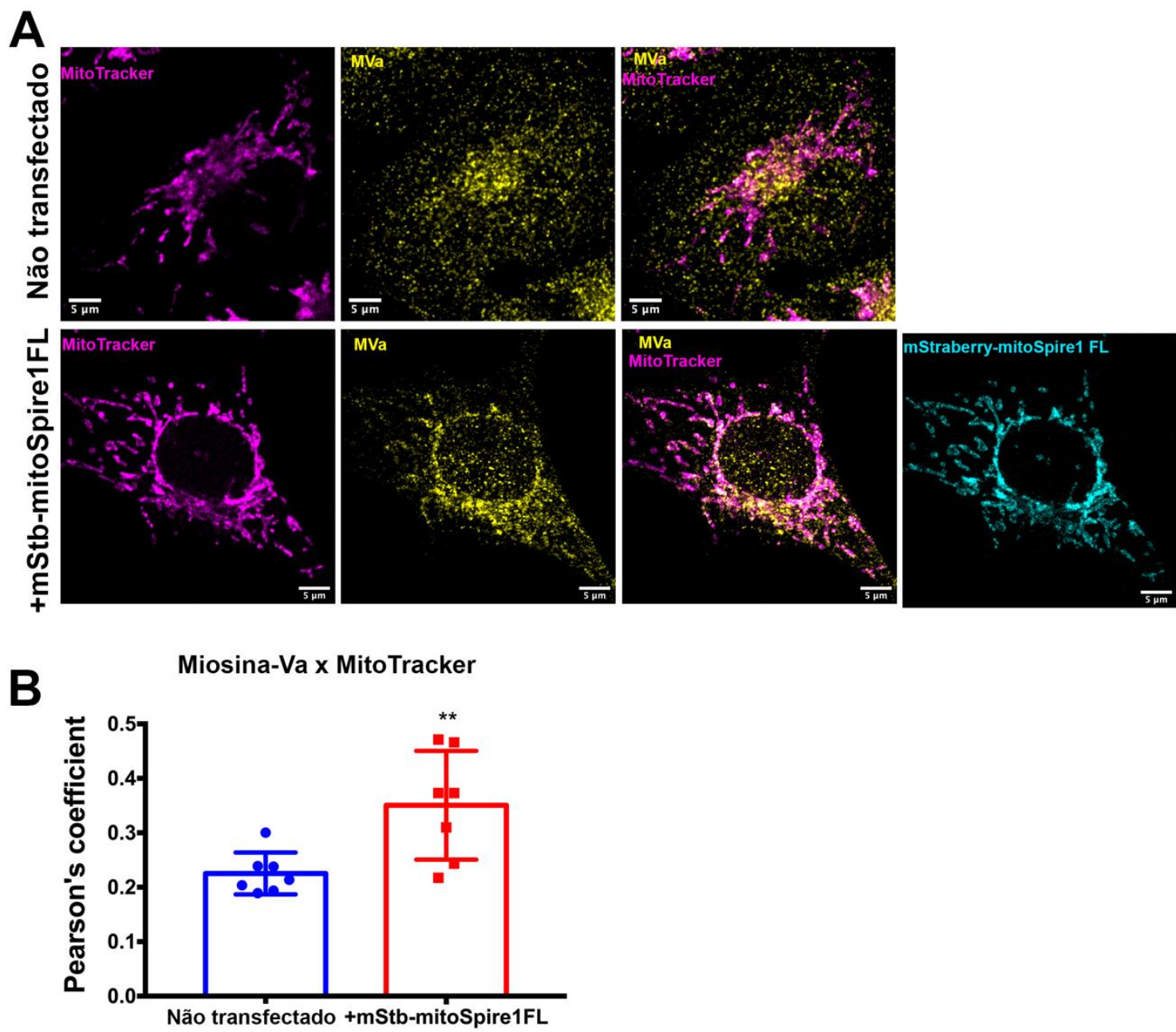

Figura 9. A miosina-Va endógena é recrutada para a MME pela superexpressão de mitoSpire1. A. Imagens de microscopia super-resolução Aryscan de células A375 não transfectadas ou transfectadas com mitoSpire1 inteira (mStb-mitoSpire1FL, mostrado em ciano, painel inferior). As imagens mostram a rede mitocondrial corada com MitoTracker DeepRed (magenta) e a imunomarcação do anti-miosina-Va policlonal produzido em coelhos (Mva, amarelo). B. Coeficiente de correlação de Pearson mostrando a colocalização da miosina-Va endógena com a rede mitocondrial em células que expressam ou não o construto da mitoSpire1 inteira. Os dados são média \pm DP. Teste t não pareado ** $\mathrm{P}<0,002$ ( $\mathrm{n} \geq 50$ células para cada condição, 3 experimentos diferentes).

Por outro lado, nós também decidimos analisar se a falta da mitoSpire1 levaria à uma diminuição da colocalização dos construtos da miosina-Va com a rede mitocondrial. Para isso, nós analisamos a colocalização do construto da cauda inteira da miosina-Va com tag GFP 
(MVa-FT-GFP) com a rede mitocondrial em células U2OS nocaute para mitoSpire1 (U2OS mitoSpire1 KO) e comparamos com células U2OS WT. Nestas células, nós transfectamos o construto MVa-FT-GFP e a rede mitocondrial foi corada com MitoTracker. Interessantemente, não houve uma diferença significativa do coeficiente de Pearson's para a colocalização do MVa-FT-GFP e MitoTracker quando comparamos células U2OS WT com mitoSpire1 KO (Figura 10).
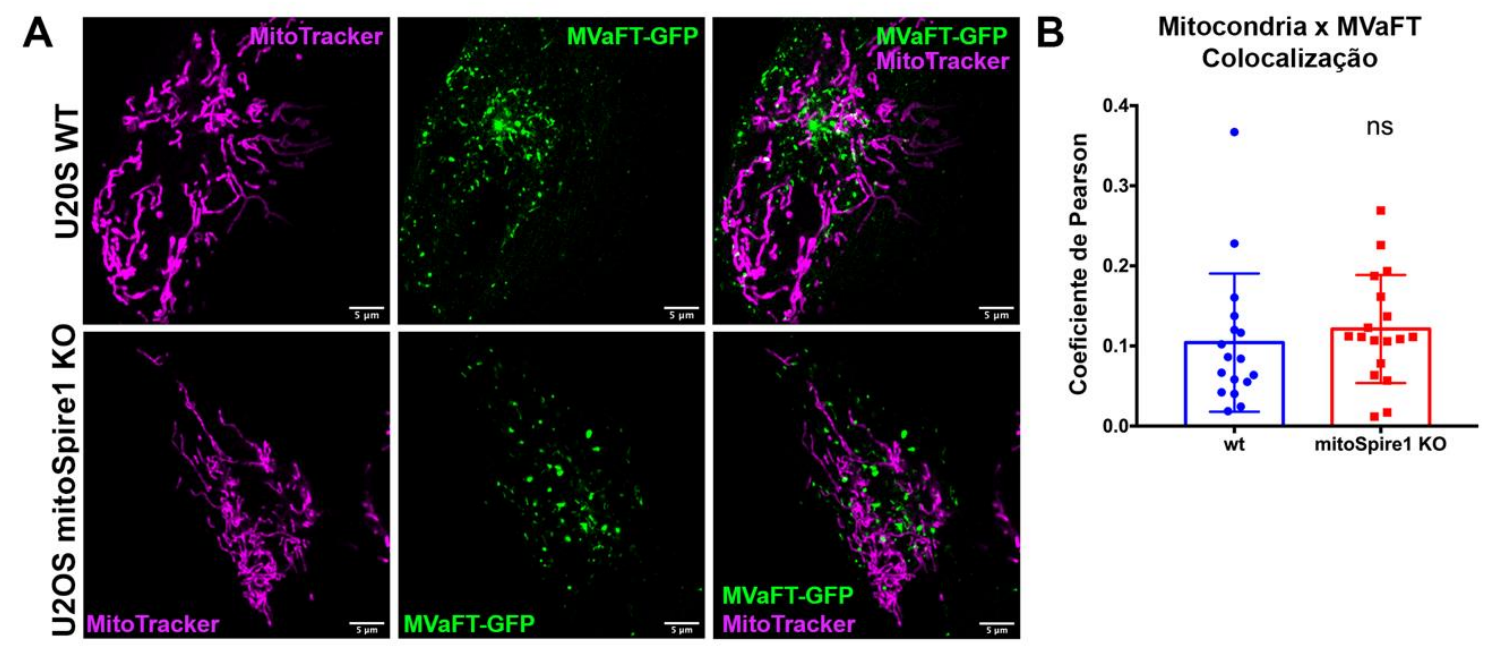

Figura 10. O nocaute da mitoSpire1 não interfere com a localização da cauda inteira da miosina-Va na rede mitocondrial. A. Imagens de microscopia de super-resolução Aryscan das células U2OS WT e U2OS mitoSpire1KO transfectadas com a cauda inteira da miosina-Va (MVaFT-GFP, em verde) e coradas com MitoTracker DeepRed (magenta). B. Coeficiente de correlação de Pearson mostrando a colocalização da cauda inteira da miosina-Va (MVaFT) com a rede mitocondrial, em células U20S WT ou mitoSpire1 KO. Os dados são média \pm DP. Teste $t$ não pareado (células $\mathrm{n} \geq 20$ para cada condição, 2 experimentos diferentes).

\subsection{A depleção da miosina-Va leva a um alongamento mitocondrial}

Com o objetivo de entender a função da miosina-Va em relação à rede mitocondrial, já que ela se associa a proteínas da MME, nós silenciamos a miosina-Va em células A375. As células A357 são provindas de melanoma metastático humano, e possuem a mutação BRAFV600E, o que torna a rede mitocondrial destas células predominantemente fragmentada, fazendo delas um útil modelo para visualizamos mudanças na morfologia mitocondrial. Para o silenciamento da miosina-Va utilizamos dois shRNAs (shMVa1 e shMVa2) que levaram a um silenciamento com 60 e $85 \%$ de eficiência, respectivamente (Figura 11A e 11B), e um shRNA inespecífico como controle.

Para investigar se o silenciamento da miosina-Va altera as mitocôndrias nessas células, nós fizemos uma imunomarcação da rede mitocondrial das células silenciadas e comparamos com as células controle. Observamos que as células silenciadas exibiram mitocôndrias mais 
longas (Figura 11C). Sendo que mais de $40 \%$ das células silenciadas mostraram mitocôndrias alongadas, enquanto apenas $12 \%$ das células shCTRL mostraram mitocôndrias alongadas. Consistentemente, a frequência de células com mitocôndrias fragmentadas estava acima de $70 \%$ nas células shCTRL e apenas cerca de 30\% nas células silenciadas para miosina-Va (Figura 11D). A determinação da morfologia mitocondrial, neste caso, foi feita a partir da observação de diversas células e classificação visual das suas redes mitocondriais. Para isso, no mínimo 150 células foram observadas para cada condição, vindas de três experimentos diferentes.
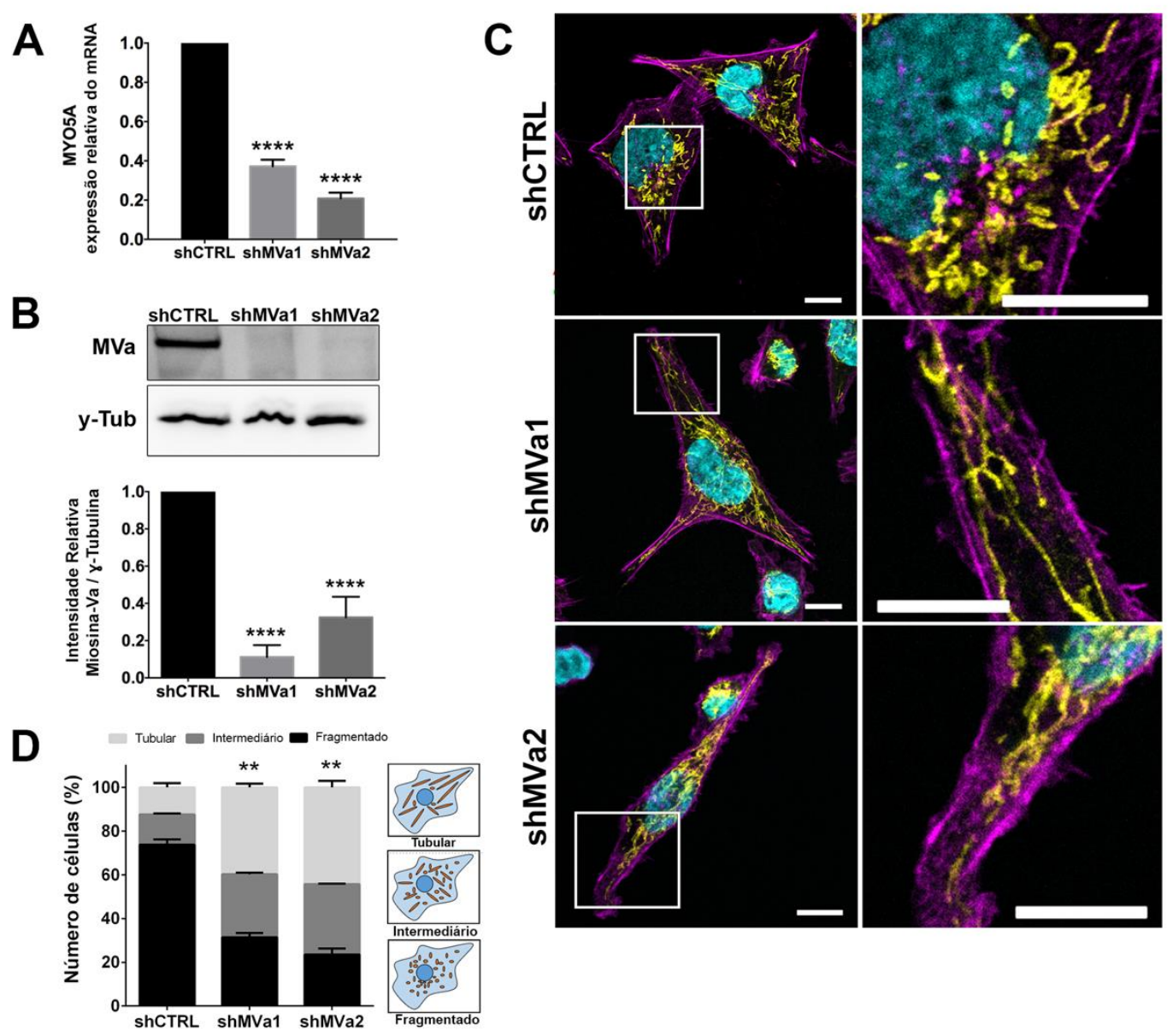

Figura 11. O silenciamento da miosina-Va promove mudanças na morfologia da rede mitocondrial. A. Expressão do mRNA de MYO5A em células A375 transduzidas com dois shRNAs diferentes (shMVa1 e shMVa2). Os valores plotados são relativos ao shCTRL. O gene GAPDH foi usado como housekeeping com a fórmula $2^{-\Delta \Delta C t}$ para normalizar o nível de expressão. Os dados são média $\pm \mathrm{DP}(\mathrm{n}=3)$, **** $\mathrm{P}<0,0001$. B. Western blot contendo lisado total das células A375 transduzidas (linha 1-shCTRL; linha 2-shMVa1 e linha 3-shMVa2) marcadas com anti-MVa (policlonal de coelho anti-cauda medial) e um anticorpo para $\gamma^{-T u b u l i n a ~(~} \mathrm{y}$-Tub) usado como normalizador. A quantificação por densitometria da miosina-Va em relação à $\gamma^{-T}$ Tubulina é mostrada abaixo. Os dados são média \pm DP $(n=3)$, **** $\mathrm{P}<0,0001$. C. Imagens de microscopia confocal a laser de células A375 silenciadas para miosina-Va (shMVa1 e shMVa2) e controle (shCTRL) mostrando a rede mitocondrial imunomarcada com anticorpo anti-TOMM20 (amarelo), a F-actina foi corada com faloidina-Alexa-594 (magenta) e os núcleos com DAPI (ciano). Barra de escala: $10 \mu \mathrm{m}$ e $1 \mathrm{~m}$ nas inserções. D. A morfologia mitocondrial foi quantificada classificando a morfologia da rede mitocondrial nas células, pelo menos 150 células foram contadas 
em três lâminas diferentes. Os dados são média \pm DP. ** $\mathrm{P}<0,001$.

Analyzed 8 Samples

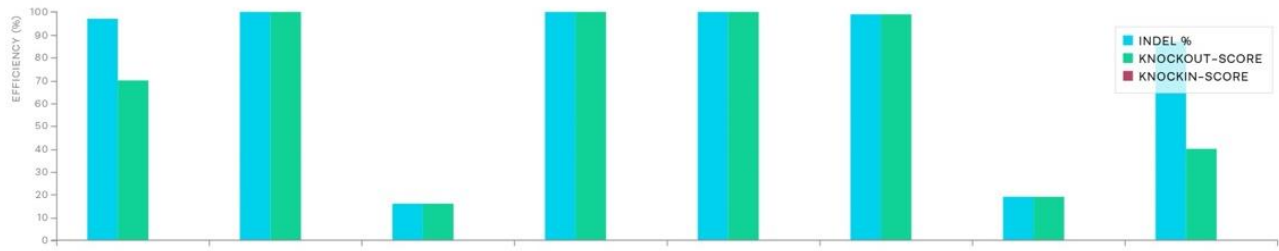

\begin{tabular}{|c|c|c|c|c|c|c|}
\hline \multirow[b]{2}{*}{ SAMPLE ๑ } & \multicolumn{5}{|c|}{ SUCCESSFULLY ANALYZED SAMPLES } & \\
\hline & - GUIDe target @ & pam SEQUenceO & INDEL \% ๑ & $\begin{array}{c}\text { MoDEL FIT } \\
\left(R^{2}\right) \circlearrowright\end{array}$ & $\begin{array}{l}\text { KNockouT- } \\
\text { SCORE } 0\end{array}$ & \\
\hline $0_{1}$ & CGAGGAGCTIGATGTCCGCA & AGG & 97 & 0.97 & 70 & viow Dotalis \\
\hline$\theta^{2}$ & CGAGGAGCTTGATGTCCGCA & AGG & 100 & 1 & 100 & Viow Dotalis \\
\hline$\theta_{3}$ & CGAGGAGCTTGATGTCCGCA & AGG & 16 & 0.16 & 16 & View Detalls \\
\hline$\theta_{4}$ & CGAGGAGCTTGATGTCCGCA & AGG & 100 & 1 & 100 & Viow Dotalis \\
\hline 05 & CGAGGAGCTIGATGTCCGCA & $A G G$ & 100 & 1 & 100 & Viow Detals \\
\hline $0_{6}$ & CGAGGAGCTTGATGTCCGCA & AGG & 99 & 0.99 & 99 & Viow Dotalis \\
\hline 07 & CGAGGAGCTTGATGTCCGCA & AGG & 19 & 0.51 & 19 & Viow Detals \\
\hline$\theta_{8}$ & CGAGGAGCTTGATGTCCGCA & AGG & 87 & 0.87 & 40 & Viow Dotalis \\
\hline
\end{tabular}

\section{A375 MYO5A KO2}

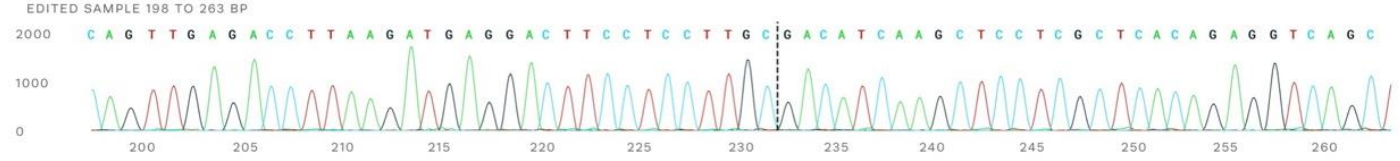

\section{A375 MYO5A KO4}

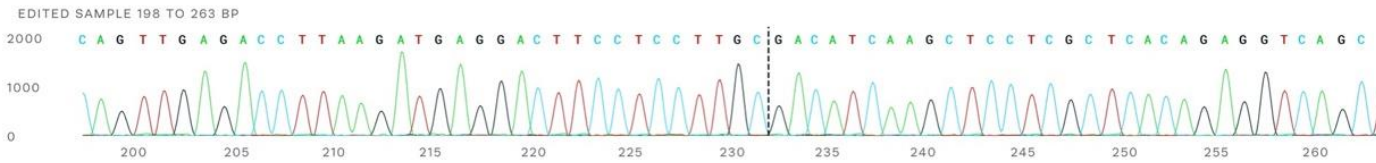

\section{A375 MYO5A KO5}

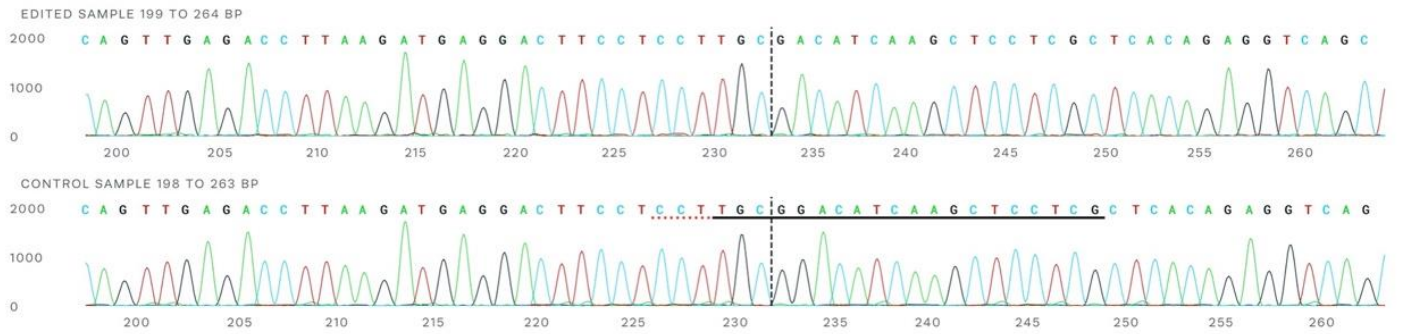

A375 WT - amostra controle

Figura 12. Eficiência do nocaute de MYO5A nos clones das células A375. Análises da eficiência do nocaute de MYO5A usando a ferramenta ICE Analysis (v2) (Synthego Performance Analysis, ICE Analysis., 2019), da Synthego. A figura mostra o "guia" utilizado para o nocaute CRISPR, a sequência "PAM" (Protospacer Adjacent Motif) para a nuclease utilizada, que foi a Streptococcus pyogenes (SpCas9). O "Indel\%" é a eficiência de edição determinada pela comparação do traço editado com o traço controle. "Model Fit $\left(R^{2}\right)$ Score" é uma medida que, quando a regressão linear ICE é calculada durante a geração da pontuação de ICE, o coeficiente de correlação de Pearson (R) também é calculado e relatado. Quanto maior o valor de $\mathrm{R}^{2}$, mais confiante é a pontuação do ICE. O "Knockout Score" é uma medida útil para entender quantos indels contribuintes têm probabilidade de resultar em um KO funcional do gene alvo. Os painéis inferiores mostram o traçado para o sequenciamento das células MYO5A 
KO2, MYO5A KO4, MYO5A KO5 e A375 WT.

Além do silenciamento da miosina-Va utilizando dos shRNAs, nós também decidimos obter linhagens CRISPR nocaute (KO) para miosina-Va. Para isso, nós também utilizamos as células A375 e realizamos nelas o nocaute através do método CRISPR-Cas9. Após a obtenção de um pool de células nocaute, nós realizamos uma seleção clonal das células, para permitir a obtenção de uma população inteiramente homogênea e com 100\% de deleção da miosina-Va. Após o isolamento clonal, foram obtidos oito clones MYO5A KO. Esses clones foram submetidos a um sequenciamento Sanger, para determinar se as células realmente não expressavam o gene MYO5A. Os dados de Sequenciamento Sanger foram analisados usando a ferramenta ICE Analysis (v2) (Synthego Performance Analysis, ICE Analysis., 2019). Desses oito clones, apenas três deles tinham 100\% de eficiência (clones 2, 4 e 5) (Figura 12). Além disso, também realizamos um western blot nos oito clones A375 MYO5A KO para demonstrar eficiência de nocaute. O resultado do western blot é mostrado na Figura 13 e é corroborativo do resultado do sequenciamento, apesar que de acordo com o resultado do western blot outros clones também são praticamente nulos para expressão da proteína miosina-Va, como o 6 e o 7 . Levando em consideração os resultados do sequenciamento e do western blot decidimos usar apenas os clones 4 e 5 em nossos experimentos posteriores.

\section{MYO5A KO clones

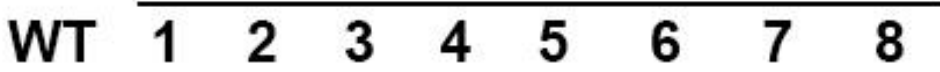

$190 \mathrm{kDa}-$

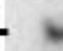

MVa

$37 \mathrm{kDa}-$

\section{GAPDH}

Figura 13. Expressão da proteína miosina-Va em células A375 MYO5A KO após expansão clonal. Western blot contendo lisado total de células A375 WT e A375 MYO5A KO clones 1-8 e marcadas com anticorpo policlonal de coelho purificado por afinidade contra cauda medial de miosina-Va ( $\mathrm{MVa}$ - anti- cauda medial) e um anticorpo policlonal para GAPDH usado como normalizador.

Para analisar se as células KO de miosina-Va (MYO5A KOs) apresentavam as mesmas características morfológicas mitocondriais das células silenciadas, nós coramos as células A375 WT (controle) e MYO5A KOs (\#4 e \#5) com MitoTracker e fizemos imagens utilizando um microscópio de super-resolução AiryScan (Figura 14A). Desta vez, para análise da morfologia 
mitocondrial destas células, nós utilizamos o plugin MiNa Morphology no ImageJ (Aj et al., 2017) (Figura 14B e 14C), que mede o tamanho dos "ramos mitocondriais" ou "linhas". Decidimos utilizar esta abordagem para análise da morfologia mitocondrial por ser um método automatizado, e, portanto, mais acurado do tamanho dos ramos mitocondriais. Notamos que tanto as células A375 MYO5A KO\#4 quanto o KO\#5 apresentaram um padrão semelhante de morfologia mitocondrial - mitocôndrias mais alongadas, pois seus ramos mitocondriais apresentaram com maior frequência tamanhos de 0,9-1,1 $\mu \mathrm{m}$ (Figura 14B e 14C). Este dado foi consistente com o que observamos anteriormente em nossas células silenciadas para miosinaVa, que também possuíam mitocôndrias mais alongadas.
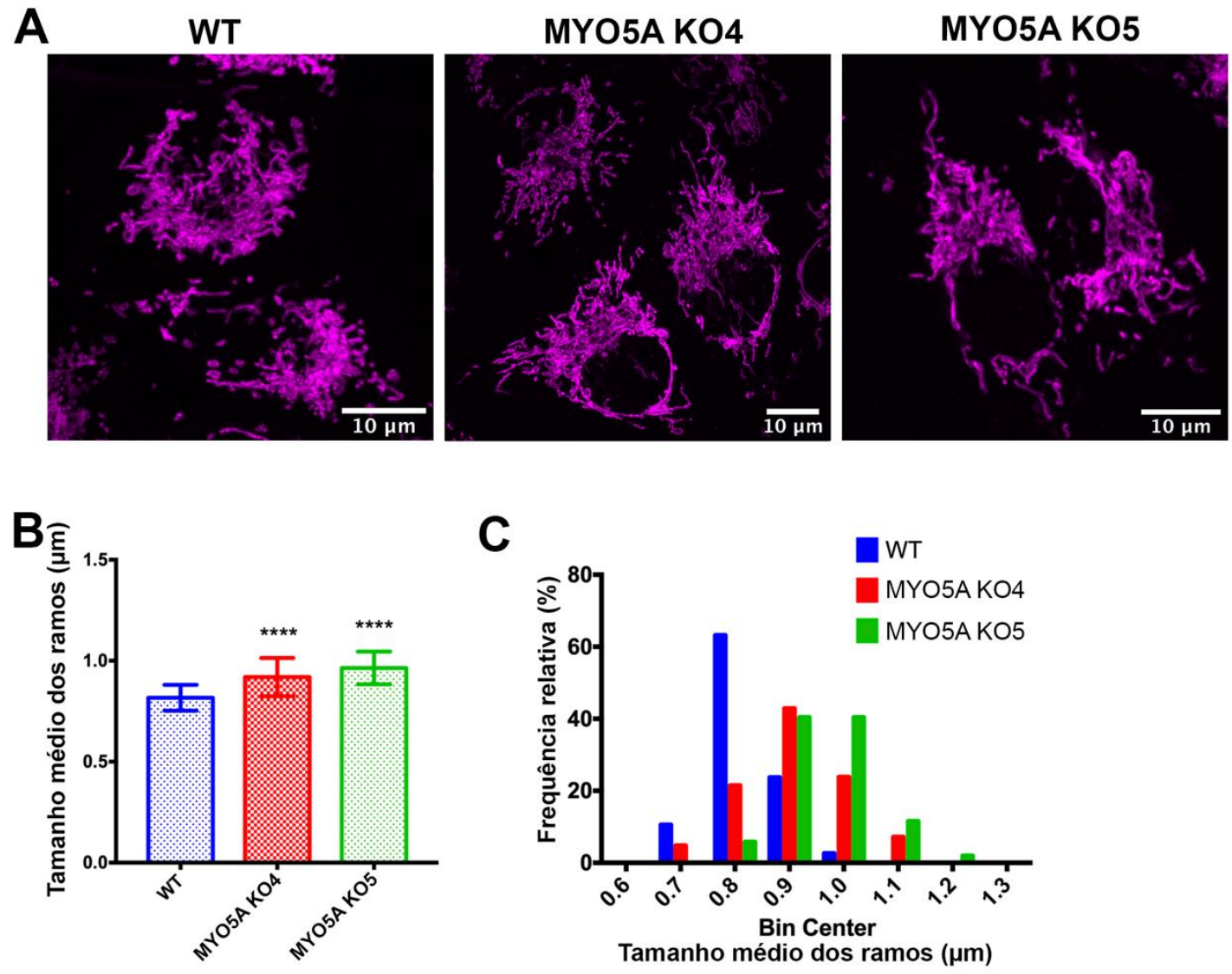

Figura 14. As células A375 MYO5A KO possuem alterações na morfologia mitocondrial. A. Imagens de microscopia de super-resolução Aryscan de células A375 WT e MYO5A KO mostrando a rede mitocondrial de corada com MitoTracker DeepRed (magenta). As imagens são representativas de um Z-stack. B. A morfologia mitocondrial foi quantificada usando o plugin MiNa Morphology no ImageJ, os gráficos de barras mostram a média dos tamanhos dos ramos mitocondriais, e C. o histograma mostra a frequência de distribuição dos comprimentos dos ramos mitocondriais. Os dados são média \pm DP. One way ANOVA **** $\mathrm{P}<0,0001$ (células $\mathrm{n} \geq 50$ para cada condição, 3 experimentos diferentes). 
Para termos uma última confirmação deste fenótipo, nós também analisamos fibroblastos provindos de um paciente com Síndrome de Griscelli tipo 1, ou seja, fibroblastos nulos para miosina-Va. Como controle, nós utilizamos fibroblastos de um doador normal, que possuía mesma idade e sexo correspondentes. Para isso, os fibroblastos humanos nulos para miosina-Va e os fibroblastos controle foram corados com MitoTracker, e utilizamos um microscópio AiryScan de super-resolução para aquição das imagens. As imagens também foram analisadas com o plugin MiNa Morphology no ImageJ (Aj et al., 2017). Observamos que os fibroblastos nulos apresentaram tamanhos médios dos ramos mitocondriais maiores, com a tamanhos médios entre 1,1 e 1,3 $\mu \mathrm{m}$, enquanto o fibroblasto controle normal apresentou a maioria de seus ramos mitocondriais com tamanhos médios em torno de 0,7 e $1,1 \mu \mathrm{m}$ (Figura 15B e 15C). Esses resultados foram consistentes com a morfologia mitocondrial que vimos nas células A375 MYO5A KO e nas células silenciadas (shMVA1 e shMVa2), e podem nos levar a concluir que a falta de miosina-Va causa o alongamento mitocondrial.
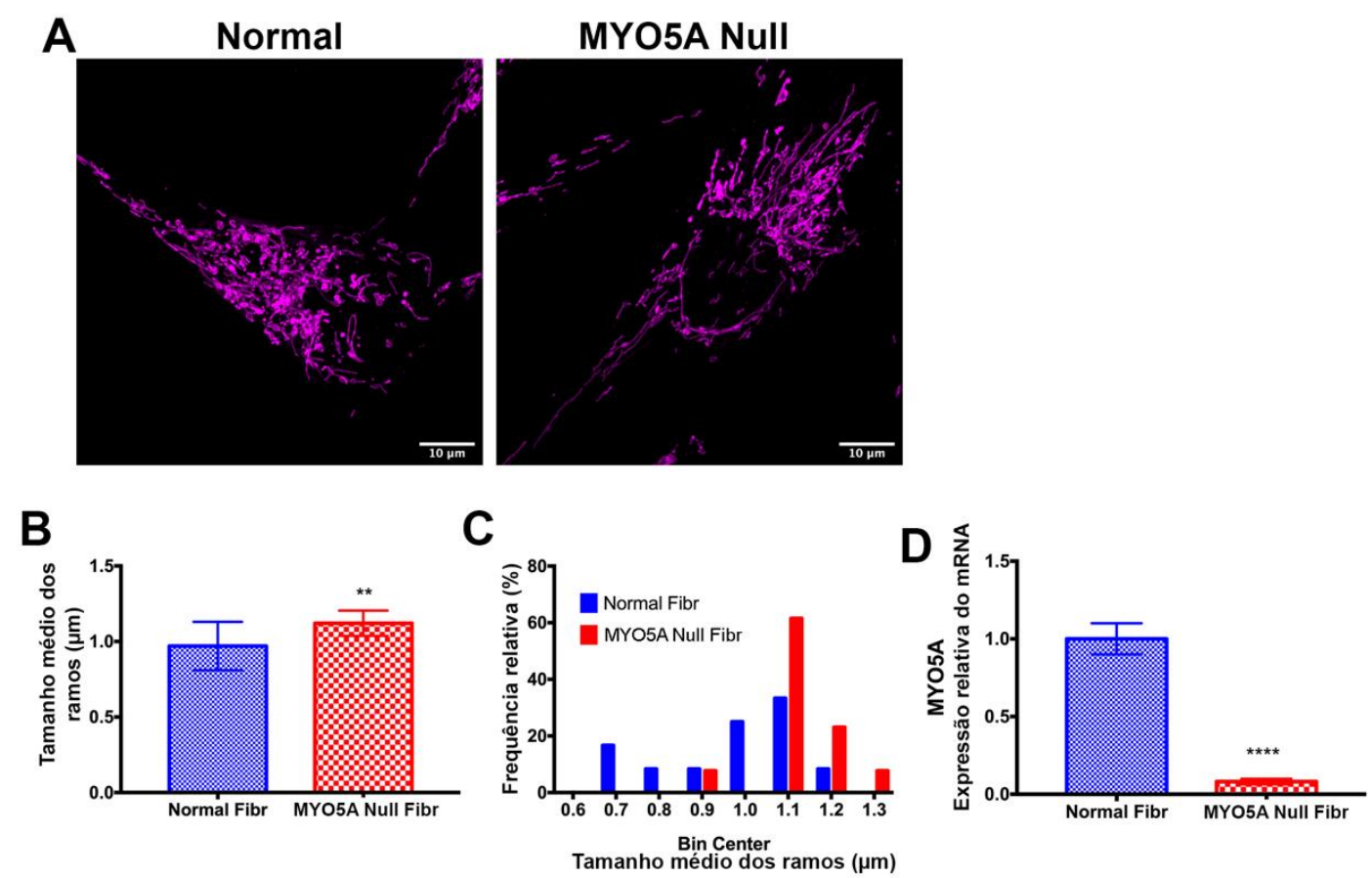

Figura 15. Fibroblastos humanos nulos para miosina-Va apresentam mitocôndrias mais alongadas do que fibroblastos humanos normais. A. Imagens de microscopia de super-resolução Aryscan de fibroblastos humanos normais e nulos para miosina-Va (MYO5A Null). As imagens mostram a rede mitocondrial das células coradas com MitoTracker DeepRed (magenta). B. A morfologia mitocondrial foi quantificada usando o plugin MiNa Morphology no ImageJ, os gráficos de barras mostram a média dos comprimentos dos ramos mitocondriais; e $\mathbf{C}$. o histograma mostra a frequência de distribuição dos comprimentos dos ramos mitocondriais. D. qRT-PCR mostrando a expressão relativa do transcrito $M Y O 5 A$ em fibroblastos normais ou fibroblastos nulos para miosinaVa. O gene GAPDH foi usado como gene housekeeping. Os dados são média $\pm \mathrm{DP}$. Teste $\mathrm{t}$ não pareado, ** $\mathrm{P}$ $<0,002$ ( $\mathrm{n}=20$ células para cada condição, 2 experimentos diferentes). 


\subsection{A superexpressão da miosina-Va reverte o fenótipo de elongação mitocondrial}

Para garantir que as mudanças observadas na morfologia mitocondrial das células MYO5A $\mathrm{KO}$ foram realmente devido à falta da proteína miosina-Va, superexpressamos um construto contendo a miosina-Va inteira com a tag GFP (MVa-FL-GFP) nas células A375 MYO5A KO (Figura 16A). Notamos que a rede mitocondrial ficou ainda mais fragmentada nas células A375 WT (Figura 16B e 16C) apresentando 15\% dos seus ramos mitocondriais com 0,6 $\mu \mathrm{m}$. O alongamento apresentado pelas células MYO5A KO também foi revertido pela superexpressão do construto MVa-FL-GFP, embora tenhamos encontrado alguns ramos mitocondriais com tamanhos $>1 \mu \mathrm{m}$, a maioria dos ramos mitocondriais teve um comprimento entre 0,6 e 0,9 $\mu \mathrm{m}$ (Figura 16B e 16C). Comprovamos a superexpressão da miosina-Va através de um western blot (Figura 16D). Nele podemos observar que as células A375 MYO5A KO apresentam novamente a marcação para miosina-Va após a superexpressão da MVa-FL-GFP. Esses resultados nos levam a concluir que o alongamento apresentado pelas células A375 MYO5A KO é realmente devido à falta da miosina-Va, uma vez que a superexpressão de um construto contendo a miosina-Va inteira é capaz de resgatar o fenótipo fragmentado apresentado pelas células A375. 
A Não transfectada
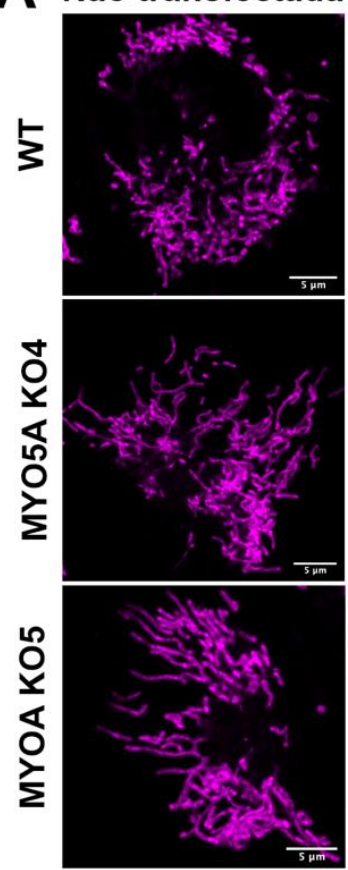

B

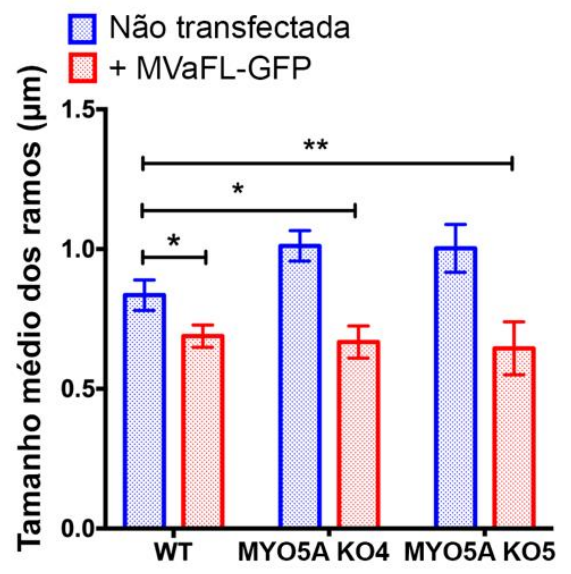

+ MVaFL-GFP
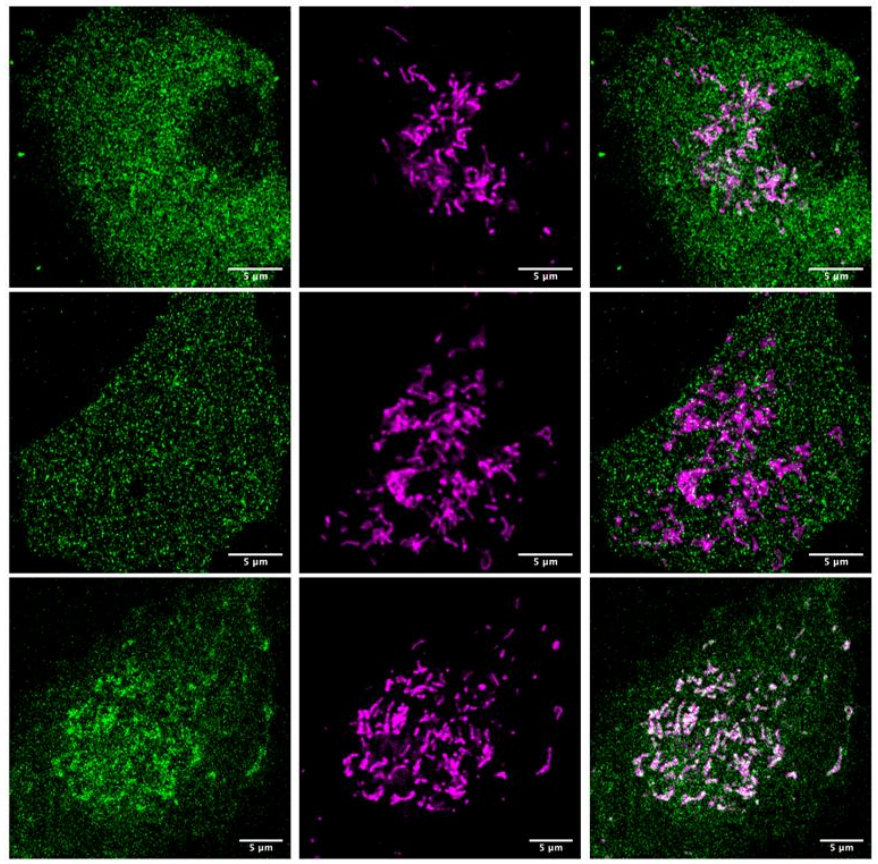

C

MYO5A KO + MVaFL-GFP

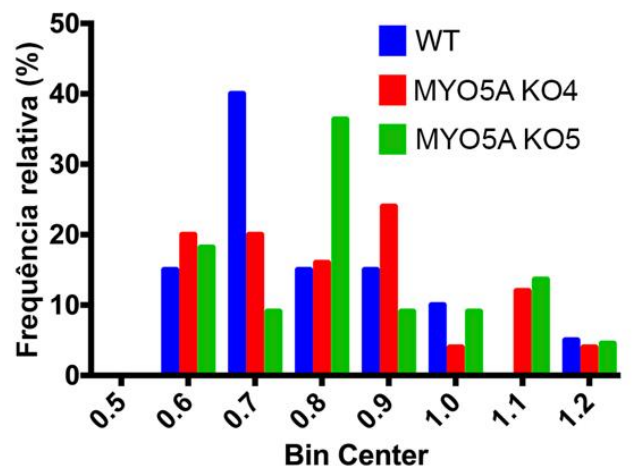

Tamanho médio dos ramos $(\mu \mathrm{m})$

D

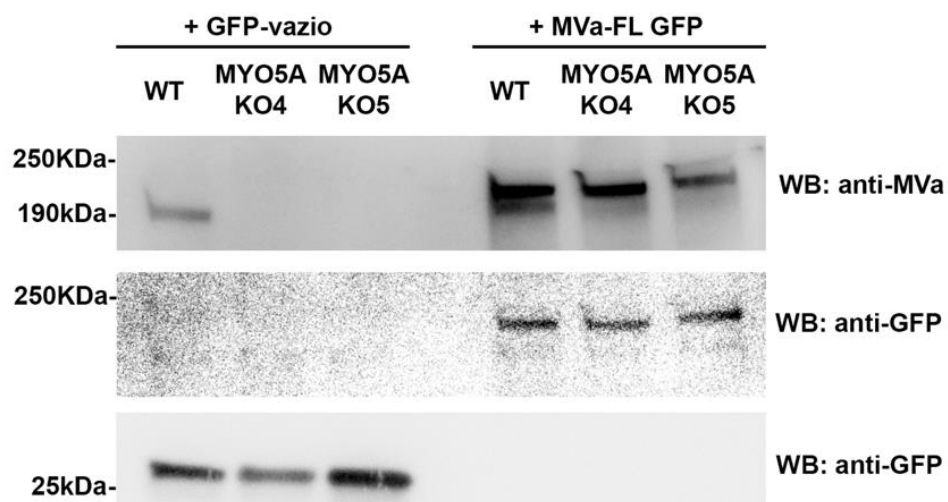

Figura 16. A superexpressão do construto da miosina-Va inteira leva a uma fragmentação da rede mitocondrial nas células A375 WT e A375 MYO5AKO. A. Imagens de microscopia de super-resolução Aryscan 
de células A375 WT e MYO5A KO não transfectadas e superexpressoras do construto MVa-FL-GFP mostrando a rede mitocondrial das células coradas com MitoTracker DeepRed (magenta), e o construto da miosina-Va inteira em verde. B. A morfologia mitocondrial foi quantificada usando o plugin MiNa Morphology no ImageJ, os gráficos de barras mostram a média dos comprimentos dos ramos mitocondriais; e C. o gráfico mostra a frequência de distribuição dos comprimentos dos ramos mitocondriais. Os dados são média \pm DP. 2-way ANOVA, ** P $<0,002$ ( $\mathrm{n}=30$ células para cada condição, 3 experiências diferentes). D. Western blot contendo os lisados totais de células A375 WT e MYO5A KO transfectadas com GFP-vazio ou com MVa-FL-GFP, marcado com anti-miosina-Va (MVa, anticorpo policlonal produzido em coelho anti-cabeça) e com anti-GFP (coelho).

\subsection{A falta da miosina-Va leva a mudanças na ultraestrutura mitocondrial}

Para entendermos melhor as mudanças morfológicas nas células silenciadas e KO para miosina-Va, utilizamos experimentos de microscopia eletrônica de transmissão (MET). As imagens de MET revelaram a presença de mitocôndrias alongadas nas células silenciadas para miosina-Va em comparação com as células shCTRL (Figura 17A). A quantificação da área (Figura 17B) e do perímetro (Figura 17C) confirmou o aumento mitocondrial das células silenciadas. Nas células A375 MYO5AKO (Figura 18A) também obtivemos resultados similares, sendo que as células $M Y O 5 A \mathrm{KO}$ apresentaram um aumento da área (18B) e do perímetro (18C) mitocondriais. Curiosamente, o comprimento das regiões de contato entre o RE e a superfície mitocondrial em relação ao comprimento total do perímetro mitocondrial também diminuiu nas células silenciadas (Figura 17D), porém nas células A375 MYO5AKO não encontramos diferenças quando medimos as regiões de contato entre o RE e a mitocôndria, comprado com as células controle A375 WT. 

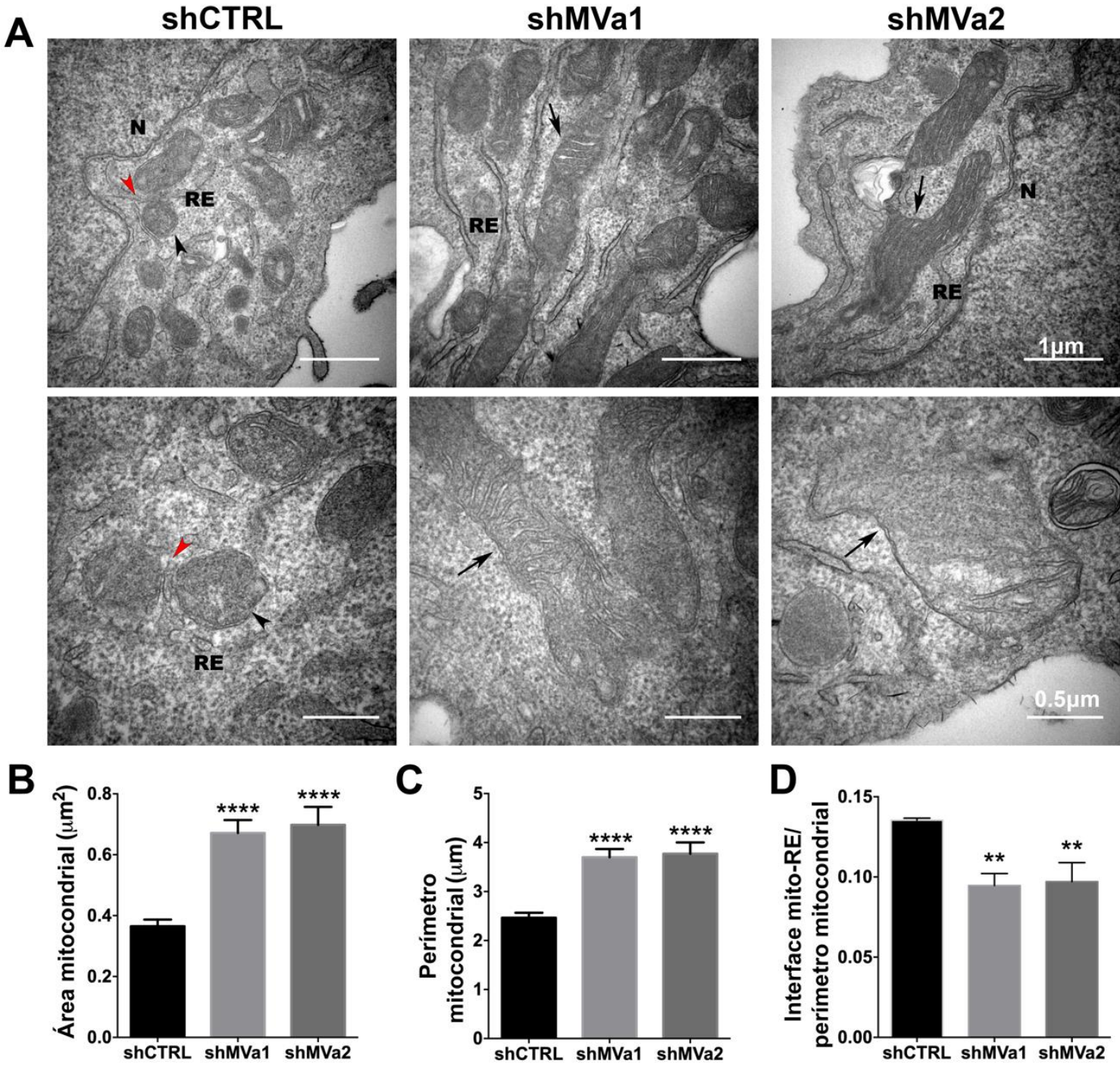

Figura 17. A ultraestrutura mitocondrial é afetada pelo silenciamento da miosina-Va na linhagem celular A375. A. Micrografias eletrônicas representativas das células A375 silenciadas para miosina-Va (shMVa1 e shMVa2) e controle (shCTRL) mostrando a ultraestrutura mitocondrial em diferentes ampliações (RE - retículo endoplasmático; $\mathrm{N}$ - Núcleo). As pontas de seta vermelhas mostram os locais de contato entre o RE e a membrana mitocondrial, as pontas de seta pretas indicam mitocôndrias fragmentadas (shCTRL); e as setas pretas mostram mitocôndrias alongadas (shMVa1 e shMVa2). B. Quantificação da área mitocondrial $\left(\mu \mathrm{m}^{2}\right)$, sendo que referente à média da área de cada mitocôndria individual, $\mathbf{C}$. quantificação do perímetro mitocondrial $(\mu \mathrm{m})$ e D. tamanho da interface RE-mitocôndria, normalizada pelo perímetro mitocondrial. Os dados são média \pm DP (pelo menos 90 mitocôndrias por condição, 2 grades). 2-way ANOVA * $\mathrm{P}<0,01$; ** $\mathrm{P}<0,001$; **** $\mathrm{P}<0,0001$. Barra de escala $=$ $2 \mu \mathrm{m}, 1 \mu \mathrm{m}, 0,5 \mu \mathrm{m}$ com ampliação de 20x (painéis da esquerda); com 40x (painéis do meio) e 80x (painéis da direita). 

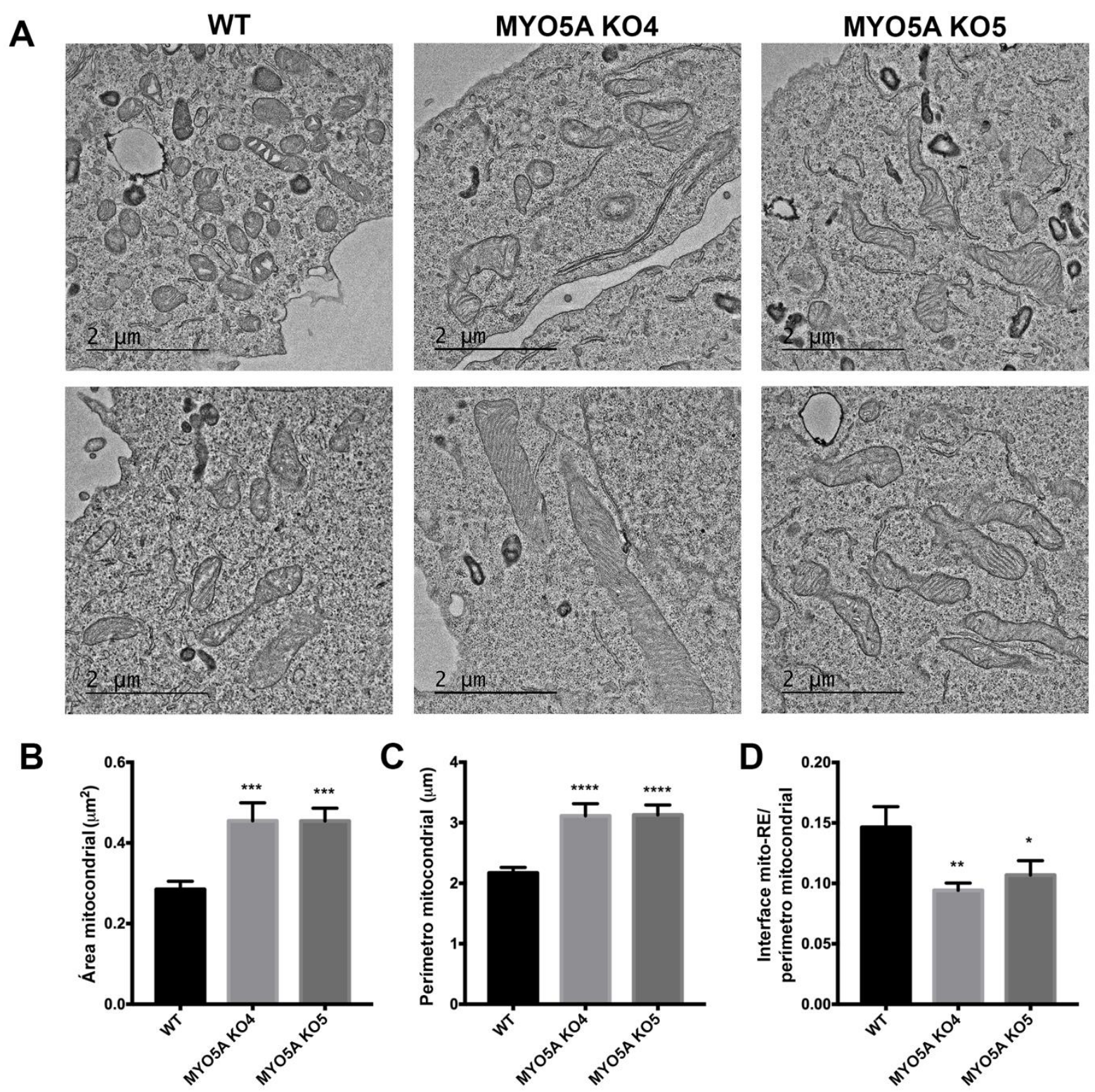

Figura 18. A ultraestrutura mitocondrial é afetada pelo nocaute da miosina-Va na linhagem celular A375. A. Micrografias eletrônicas representativas das células A375 WT e A375 MYO5AKO 4 e 5 mostrando a ultraestrutura mitocondrial. B. Quantificação da área mitocondrial $\left(\mu \mathrm{m}^{2}\right)$, C. quantificação do perímetro mitocondrial $(\mu \mathrm{m})$ e D. tamanho da interface RE-mitocôndria, normalizada pelo perímetro mitocondrial. Os dados são média $\pm \mathrm{DP}$ (pelo menos 80 mitocôndrias por condição, 2 grades). 2 -way ANOVA $* \mathrm{P}<0,01 ; * * \mathrm{P}<0,001$; $* * * * \mathrm{P}<0,0001$. Barra de escala $=2 \mu \mathrm{m}$.

\subsection{Expressão e influência das miosinas de classe $\mathrm{V}$ na morfologia mitocondrial em células A375}

Como a miosina-Va faz parte da classe de miosinas-V, que possuem dois outros membros, a miosina- $\mathrm{Vb}$ e a miosina- $\mathrm{Vc}$, nós decidimos investigar se estas proteínas também teriam algum tipo de influência na morfologia mitocondrial. Entretanto, primeiramente nós 
procuramos responder o quão expressas a miosinas- $\mathrm{Vb}$ e miosina-Vc eram em células A375, em comparação com os níveis da miosina-Va. Para isso, nós analisamos por qRT-PCR os níveis de expressão dos mRNAs da miosina-Vb e miosina-Vc nas células A375 WT (Figura 19A). Observamos que a miosina-Va é a proteína pertencente à classe de miosina-V mais abundantemente expressa nestas células. A partir disso, nós também analisamos se as células A375 MYO5AKO apresentariam diferenças na expressão dos transcritos da miosina-Vb e miosina-Vc. Notamos que não há diferença significativas na expressão destes transcritos em células A375 MYO5AKO quando comparadas com células controle (Figura 19B). O que nos leva a crer que não há mecanismos compensatórios por parte de ambas miosinas- $\mathrm{Vb} / \mathrm{Vc}$ quando há perca da função da miosina-Va.
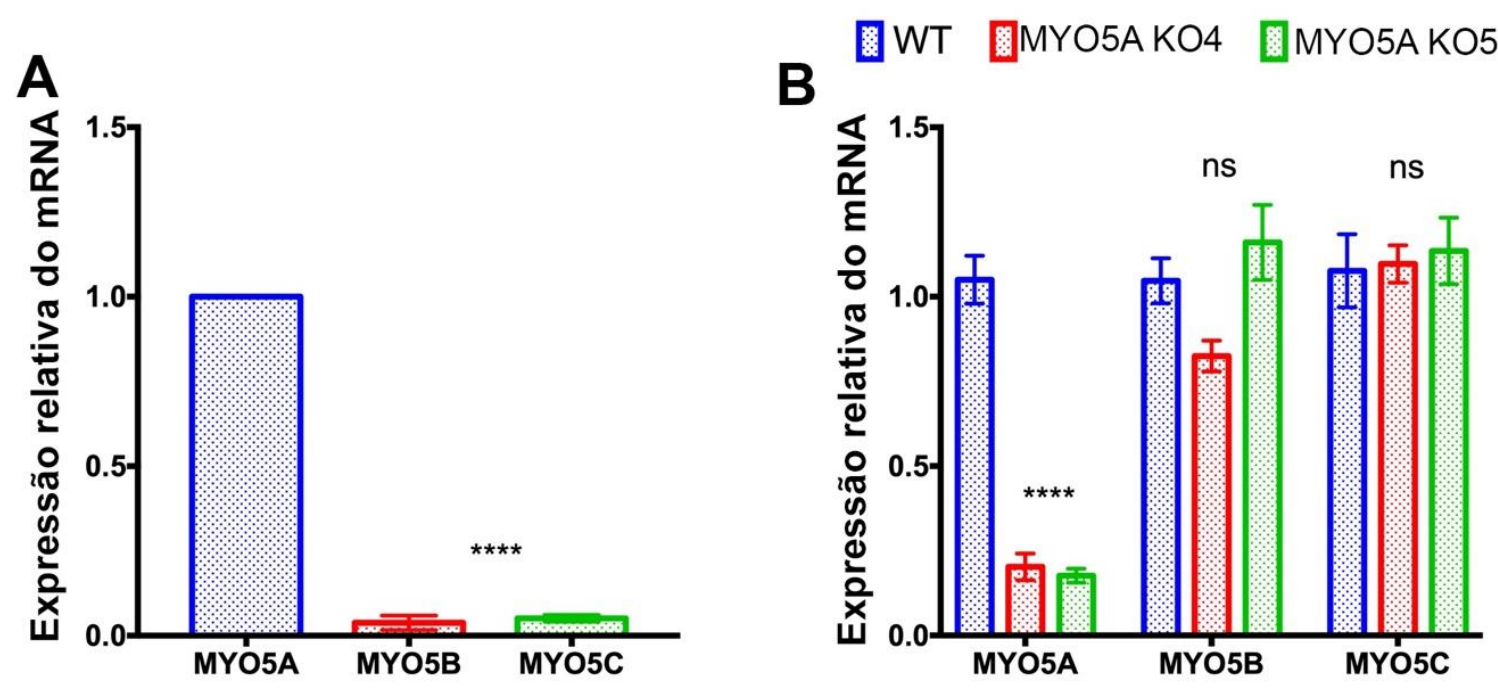

Figura 19. MYO5A é o membro mais abundante da família MYO5 em células A375. A. qRT-PCR mostrando a expressão relativa dos transcritos $M Y O 5 A, M Y O 5 B$ e $M Y O 5 C$ em células A375. A expressão do transcrito MYO5A foi usada como referência, e o gene GAPDH foi usado como gene housekeeping. B. qRT-PCR mostrando a expressão relativa dos transcritos MYO5A, MYO5B e MYO5C em células A375 WT e A375 MYO5A KOs níveis de expressão da célula WT foram usadas como referência, e o gene GAPDH foi usado como gene housekeeping. A fórmula $2^{-\Delta \Delta \mathrm{Ct}}$ foi usada para normalizar o nível de expressão. Os dados são média \pm DP. One way ANOVA, $* * * * \mathrm{P}<0,0001$ ( $\mathrm{n}=3$ experimentos diferentes).

Pensando agora na possível influência da miosina-Vb e da miosina-Vc na morfologia mitocondrial das células $\mathrm{A} 375$, nós silenciamos tanto a miosina- $\mathrm{Vb}$ quanto a miosina- $\mathrm{Vc}$ usando siRNAs nas células A375 WT e A375 MYO5A KO, e analisamos a morfologia mitocondrial a partir da marcação com MitoTracker (Figura 20A). Nós observamos que, nas células WT, houve um leve alongamento dos ramos mitocondriais quando silenciamos simultaneamente as miosinas-Vb/Vc. Curiosamente, a depleção combinada de qualquer 

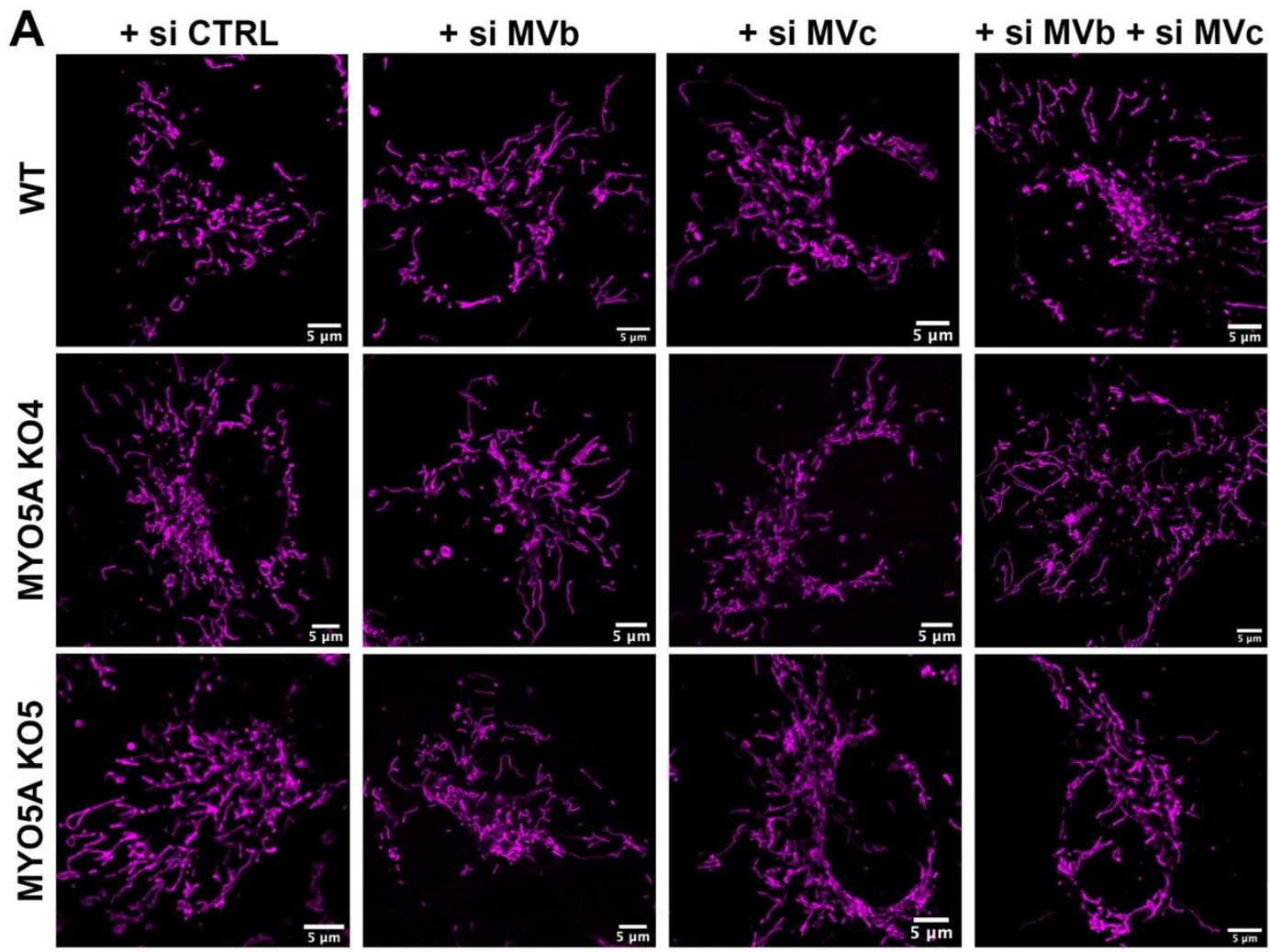

B

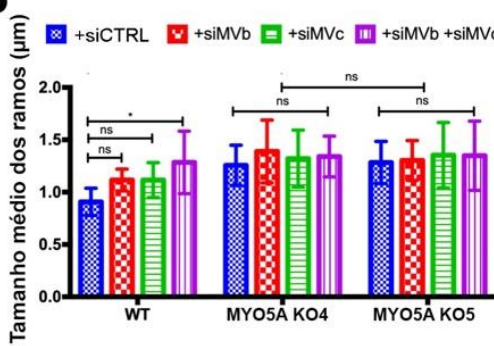

D

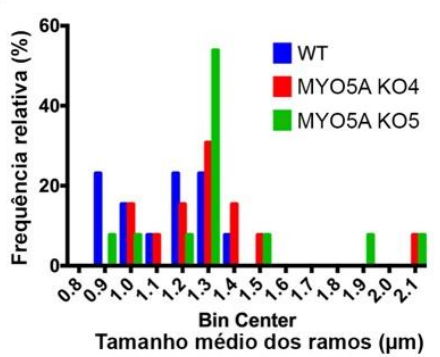

C

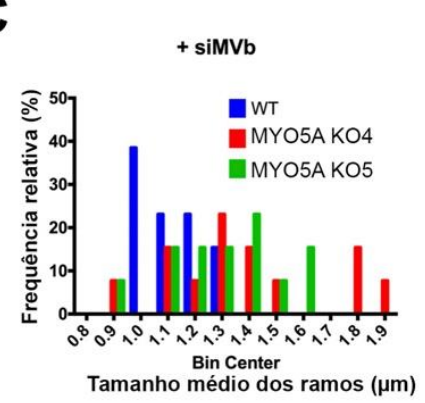

E

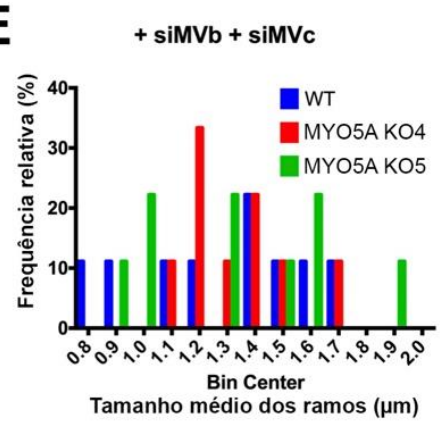

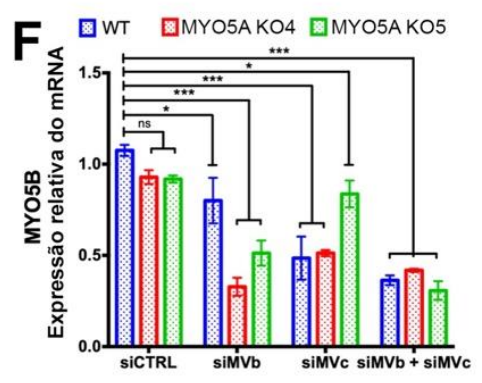

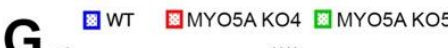

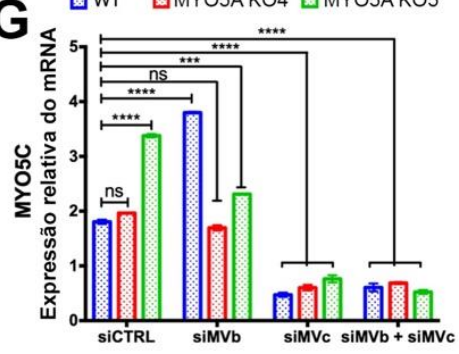

Figura 20. O silenciamento da miosina-Vb e miosina-Vc com siRNAs não altera a morfologia mitocondrial de células A375. A. Imagens de microscopia de super-resolução Aryscan de células A375 WT e MYO5A KO não transfectadas e silenciadas com siRNAs contra miosina- $\mathrm{Vb}$, miosina- $\mathrm{Vc}$ e ambas miosina- $\mathrm{Vb} / \mathrm{Vc}$, respectivamente. As imagens mostram a rede mitocondrial das células coradas com MitoTracker DeepRed (magenta). B. A morfologia mitocondrial foi quantificada usando o plugin MiNa Morphology no ImageJ, os gráficos de barras mostram a média dos comprimentos dos ramos mitocondriais, e os histogramas mostram a distribuição da 
frequência dos comprimentos dos ramos mitocondriais, em células A375 WT e MYO5A KO silenciadas com C. siRNA contra miosina-Vb; D. siRNA contra miosina-Vc; e E. siRNA contra ambas miosina-Vb e miosina-Vc. Os dados são média \pm DP. 2-way ANOVA, ** $\mathrm{P}<0,002(\mathrm{n}=20$ células para cada condição, 2 experimentos diferentes). qRT-PCR mostrando a expressão relativa dos transcritos F. MYO5B e G. MYO5C em células A375 WT e A375 MYO5A KOs tratadas com diferentes siRNAs. Os níveis de expressão de uma célula WT não transfectada foram usadas como referência, e o gene GAPDH foi usado como gene housekeeping. A fórmula 2-

$\Delta \Delta \mathrm{Ct}$ foi usada para normalizar o nível de expressão. Os dados são média \pm DP. One way ANOVA, $* * * * \mathrm{P}<0,0001$ $(\mathrm{n}=2$ experimentos diferentes).

miosina-V em células A375 MYO5A KO não causou um aumento significativo, além do aumento já causado pela depleção da miosina-Va, no comprimento dos ramos mitocondriais (Figura 20B). É importante ressaltar que o nível de silenciamento causado pelo siRNA contra mioisna-Vb não foi tão eficiente sozinho (Figura 20F), e que o próprio siCTRL gerou algumas alterações na expressão de ambas miosinas-Vb/Vc (Figura 20F-G)

\subsection{A depleção da miosina-Va altera a morfologia dos nucleóides de mtDNA}

Como já é sabido, as mudanças na morfologia mitocondrial podem estar relacionadas a mudanças na estrutura dos nucleóides de mtDNA (Ashley and Poulton, 2009; Lewis et al., 2016). Tendo isso em vista, também analisamos a morfologia dos nucleóides de mtDNA a partir da marcação das células A375 WT e MYO5A KO utilizando Picogreen e MitoTracker, e adquirimos imagens utilizando um microscópio de super-resolução AiryScan (Figura 21A). Observamos que as células A375 MYO5A KO possuem nucleóides de mtDNA com menor volume e área (Figura 21B e 21C), mas não possuíam alterações no número total de nucleóides por célula (Figura 21D).

A fim de confirmar o papel da miosina-Va nas mudanças morfológicas observadas nos nucleóides do mtDNA, nós também superexpressamos o construto MVa-FL-GFP nas células A375 WT e MYO5A KO com a hipótese de que as mudanças nos nucleóides de mtDNA seriam revertidas. Para este experimento, tivemos que imunomarcar as células com um anticorpo antiDNA (para visualização do mtDNA), e o seu sinal é ligeiramente diferente do sinal apresentado pelo marcador Picogreen. Portanto, a escala das medidas de área e volume dos nucleóides de mtDNA corados com anticorpo anti-DNA foram um pouco diferentes dos parâmetros obtidos com Picogreen. Apesar deste viés metodológico, foi possível notar que após a superexpressão de MVa-FL-GFP, as células A375 MYO5A KO apresentavam nucleóides de mtDNA com áreas e volumes muito semelhantes aos das células A375 WT (Figura 22 E-G), e novamente, não observamos alterações no número total de nucleóides por célula (Figura 22H). 
A
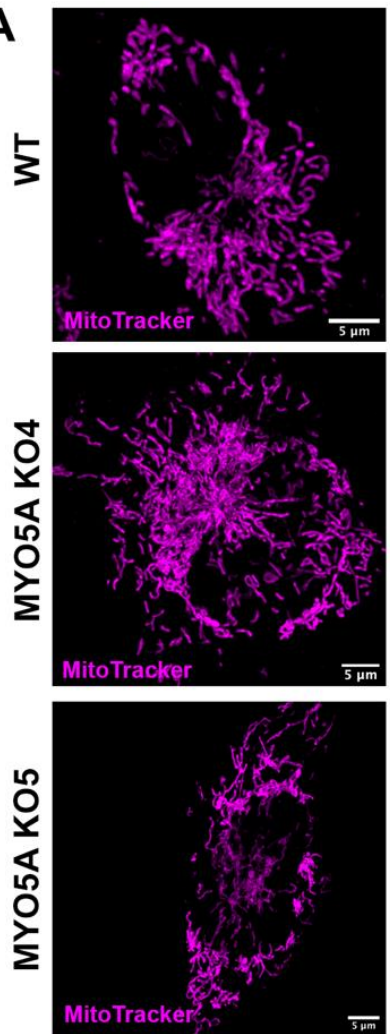
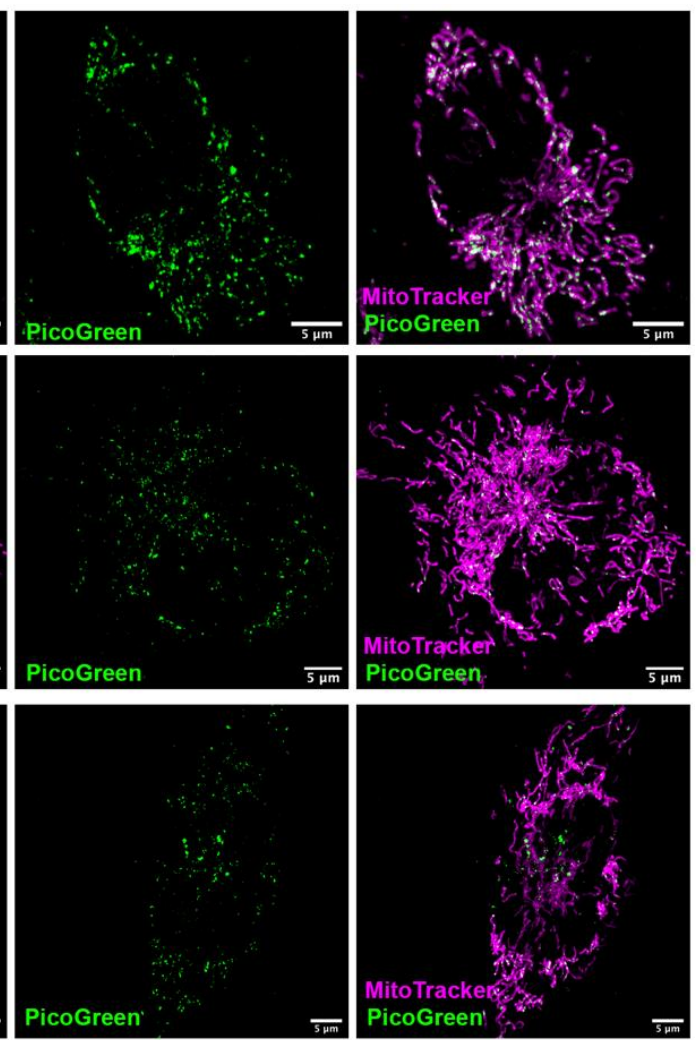

B
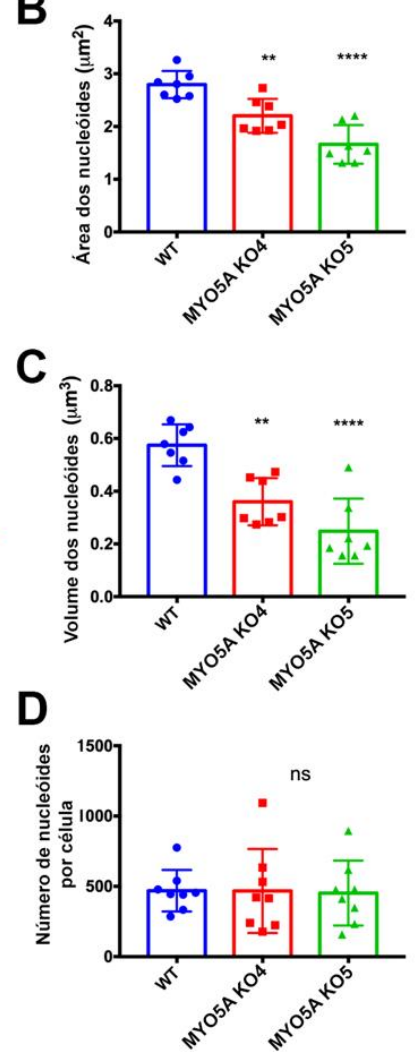

Figura 21. Os nucleóides de mtDNA têm menor área e volume nas células A375 MYO5A KO. A. Imagens de microscopia de super-resolução Aryscan de células A375 WT e MYO5A KO. As imagens mostram a rede mitocondrial das células coradas com MitoTracker DeepRed (magenta) e os nucleóides do mtDNA corados com PicoGreen (verde). B. A morfologia do mtDNA foi analisada utilizando o software Imaris. Os gráficos de barras mostram a média da área dos nucleóides do mtDNA, C. o volume, e D. o número total de nucleóides por célula. Os dados são média \pm DP. One-way ANOVA *** $\mathrm{P}<0,0002$ ( $\mathrm{n}=10$ células para cada condição, 3 experimentos diferentes). 

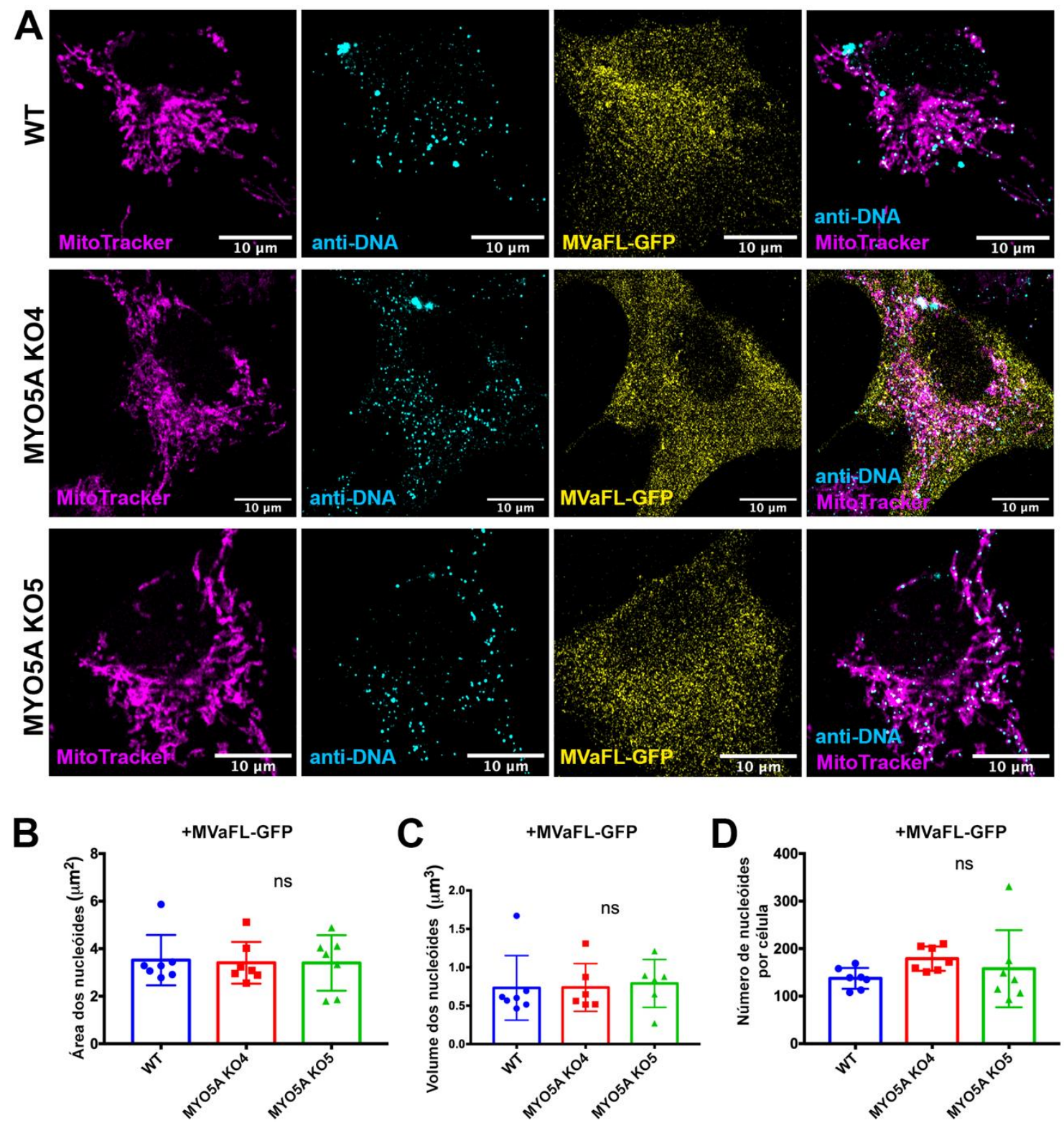

Figura 22. A superexpressão da miosina-Va inteira leva a uma reversão das alterações morfológicas dos nucleóides de mtDNA nas células A375 MYO5A KO. A. Imagens de microscopia de super-resolução Aryscan de células A375 WT e MYO5A KO. As imagens mostram a rede mitocondrial de células coradas com MitoTracker DeepRed (magenta), os nucleóides de mtDNA imunomarcados com anti-DNA (ciano) e a superexpressão do construto da miosina-Va inteira (MVaFL-GFP em amarelo). B. A morfologia dos nucleóides foi analisada usando o software Imaris, os gráficos de barras mostram a média da área dos nucleóides, C. do volume, e D. o número total de nucleóides por célula. Os dados são média \pm DP. One-way ANOVA, $(\mathrm{n}=10$ células para cada condição, 2 experimentos diferentes).

Devido às alterações observadas no mtDNA após a depleção da miosina-Va, nós também analisamos se havia alguma alteração no número de cópias do mtDNA entre as células A375 WT e MYO5A KO. Para isso, nós comparamos a expressão do mRNA de um gene mitocondrial (ND4), com a expressão de um gene do DNA nuclear (nDNA). Observamos que as células MYO5A KO não possuem diferenças no número de cópias de mtDNA, quando 
comparadas com as células controle (Figura 23A). A partir desta observação, analisamos também a expressão de PGC1 $\alpha$, um regulador mestre da biogênese mitocondrial e a expressão de TFAM, um gene regulado por PGC1 $\alpha$ e de extrema importância na compactação do mtDNA. Observamos que também não havia diferenças significantes na expressão dos mRNA de PGC1 $\alpha$ e TFAM nas células MYO5A KO, quando comparadas com as células controle (Figura 23B).
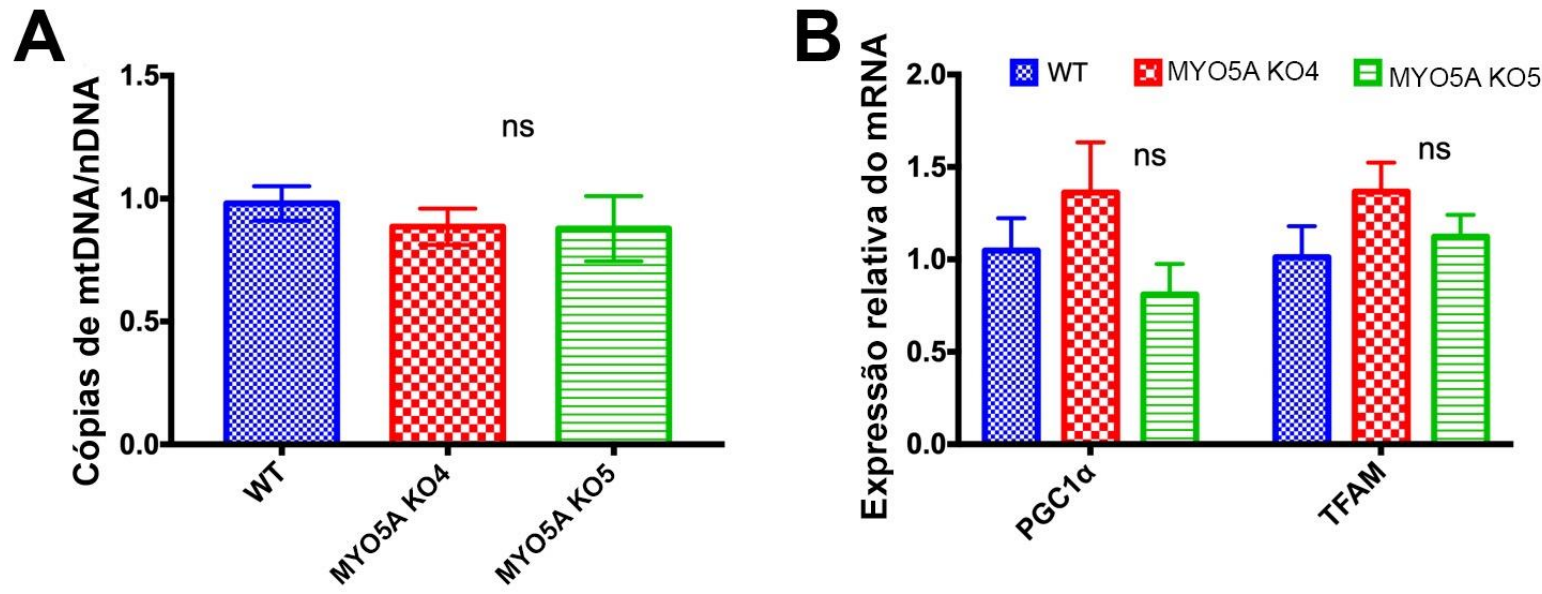

Figura 23. O nocaute da miosina-Va não altera o número de cópias do mtDNA, assim como a expressão de PGC1 $\alpha$ e TFAM. A. qRT-PCR para determinar o número de cópias de mtDNA nas células A375 WT e A375 MYO5A KOs. Um gene específico para o nDNA ( $\beta 2 \mathrm{M}$, que possui baixa variabilidade e possui cópia única) foi usado como normalizador para quantificação relativa do mtDNA (amplificado através do gene ND4, que codifica a subunidade 4 da NADH-ubiquinona oxidoredutase). B. qRT-PCR mostrando a expressão relativa dos transcritos PGC1 $\alpha$ e TFAM em células A375 WT e A375 MYO5A KOs. O gene GAPDH foi usado como gene housekeeping. A fórmula $2^{-\Delta \Delta C t}$ foi usada para normalizar o nível de expressão. Os dados são média \pm DP. One-way ANOVA para o gráfico mostrado em A, e 2-way ANOVA para o gráfico mostrado em B. 3 experimentos independentes.

\subsection{A depleção da miosina-Va e o balanço das proteínas da dinâmica mitocondrial}

Para entender se as alterações na morfologia mitocondrial afetavam a expressão de genes e seus respectivos produtos proteicos envolvidos na dinâmica mitocondrial, realizamos análises da expressão de mRNA e de proteínas nas células A375 silenciadas para miosina-Va (shMVa1 e shMVa2) e controle (shCTRL). O mRNA Drp1 e as proteínas Drp1, ambas Drp1 total e Drp1 p(S616), não se mostraram alterados nas células silenciadas quando comparadas ao controle (Figura 24A-C). Já os níveis de mRNA de Mfn1 e Mfn2 estavam ligeiramente diminuídos, mas nenhuma alteração nos níveis de proteína foi observada (Figura 24A-C). A expressão de mRNA de OPA1 se encontrava aumentada, mas nenhuma alteração dos níveis da proteína OPA1 foi detectada (Figura 24A-C). Estas pequenas alterações nos parecem ser 
devidas a uma tentativa regulatória causada pelo alongamento mitocondrial observado após o silenciamento da miosina-Va.
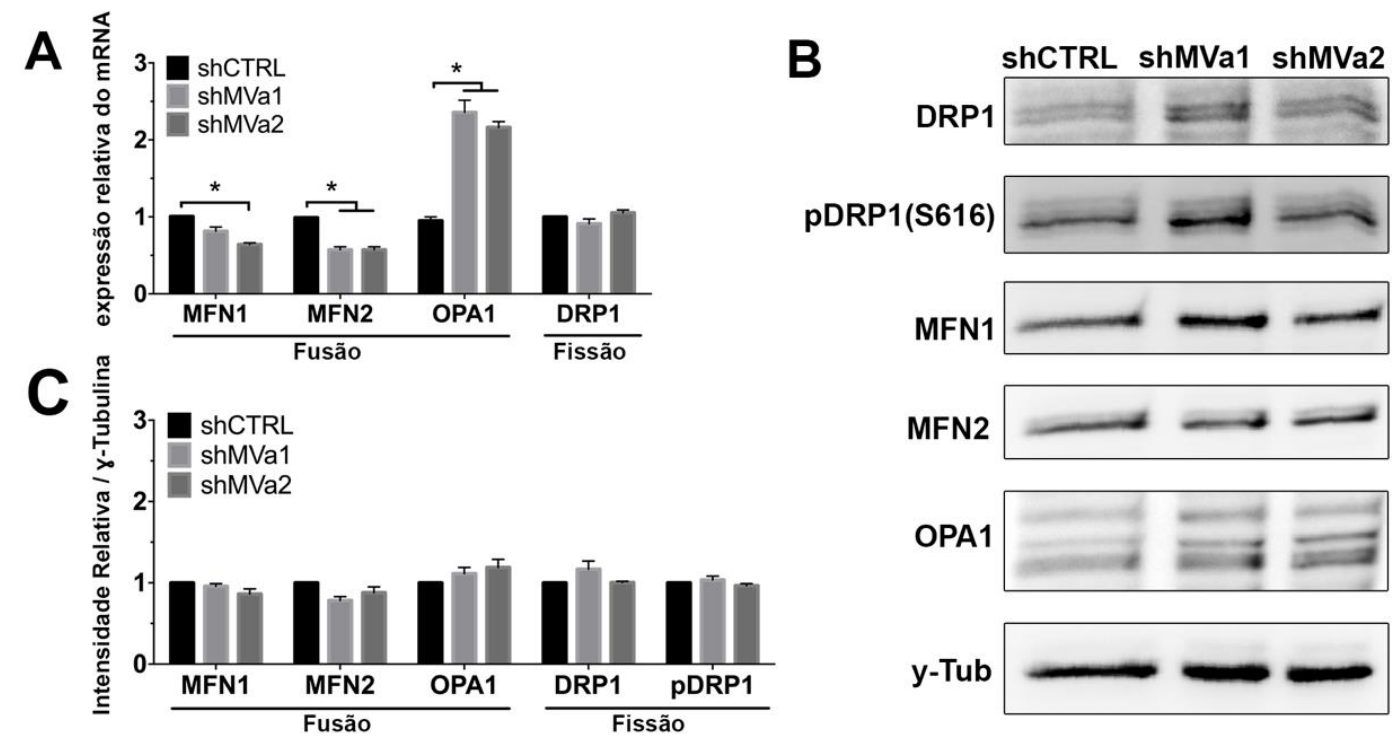

Figura 24. O silenciamento da miosina-Va altera a expressão dos genes relacionados à dinâmica mitocondrial. A. qRT-PCR mostrando a expressão relativa dos transcritos de alguns genes relacionados à dinâmica mitocondrial em células A375 shCTRL e silenciadas para miosina-Va (shMVa1 e shMVa2). O gene GAPDH foi usado como gene housekeeping. B. Western blots contendo lisado total de células A375 (linha 1shCTRL; linha 2-shMVa1 e linha 3-shMVa2) marcados com anticorpos contra Drp1, p(S616)Drp1, Mfn1, Mfn2, Opa1 e $\gamma^{-T u b u l i n a ~(~} \gamma$-Tub). A $\mathrm{\gamma}$-tubulina foi utilizada como normalizador. C. Gráfico representativo da quantificação densitométrica das proteínas de $\mathbf{B}$ em relação à $\gamma$-Tubulina. Os dados são a média \pm DP de três experimentos independentes. 2-way ANOVA, * $\mathrm{P}<0,01 ; * * \mathrm{P}<0,001 ; * * * \mathrm{P}<0,0005$.

Decidimos analisar também a colocalização de tais proteínas com a rede mitocondrial nas células silenciadas para miosina-Va, visto que são proteínas que necessitam da interação com a rede mitocondrial para efetuarem suas respectivas funções com relação à dinâmica mitocondrial. Para isso, fizemos a imunomarcação das proteínas envolvidas na dinâmica mitocondrial (Drp1, Drp1 p(S616), Mfn1 e Mfn2) juntamente com citocromo c, como marcador mitocondrial. Podemos observar na Figura 25A e 25B que há uma diminuição na colocalização da Drp1 com a rede mitocondrial. Quando analisamos a fosforilação de Drp1 na posição S616, que é uma fosforilação ativadora e necessária para função da Drp1 na fissão mitocondrial, observamos que há também uma diminuição da colocalização da Drp1 p(S616) com a rede mitocondrial nas células silenciadas para miosina-Va (Figura 25C e 25D). Quanto a Mfn1, observamos que esta proteína também teve a sua colocalização com a rede mitocondrial reduzida (Figura 25E e 25F). Já para Mfn2, curiosamente, observamos que a sua colocalização 
com a rede mitocondrial foi aumentada nas células silenciadas para miosina-Va, quando comparado com células controle (Figura $25 \mathrm{G}$ e $25 \mathrm{H}$ ). Este dado pode ser interessante, porque Mfn2, ao contrário de Mfn1, está relacionada também a manutenção do contato entre as membranas da mitocôndria e do RE, o que é importante para diversas funções destas organelas (Schrepfer and Scorrano, 2016).

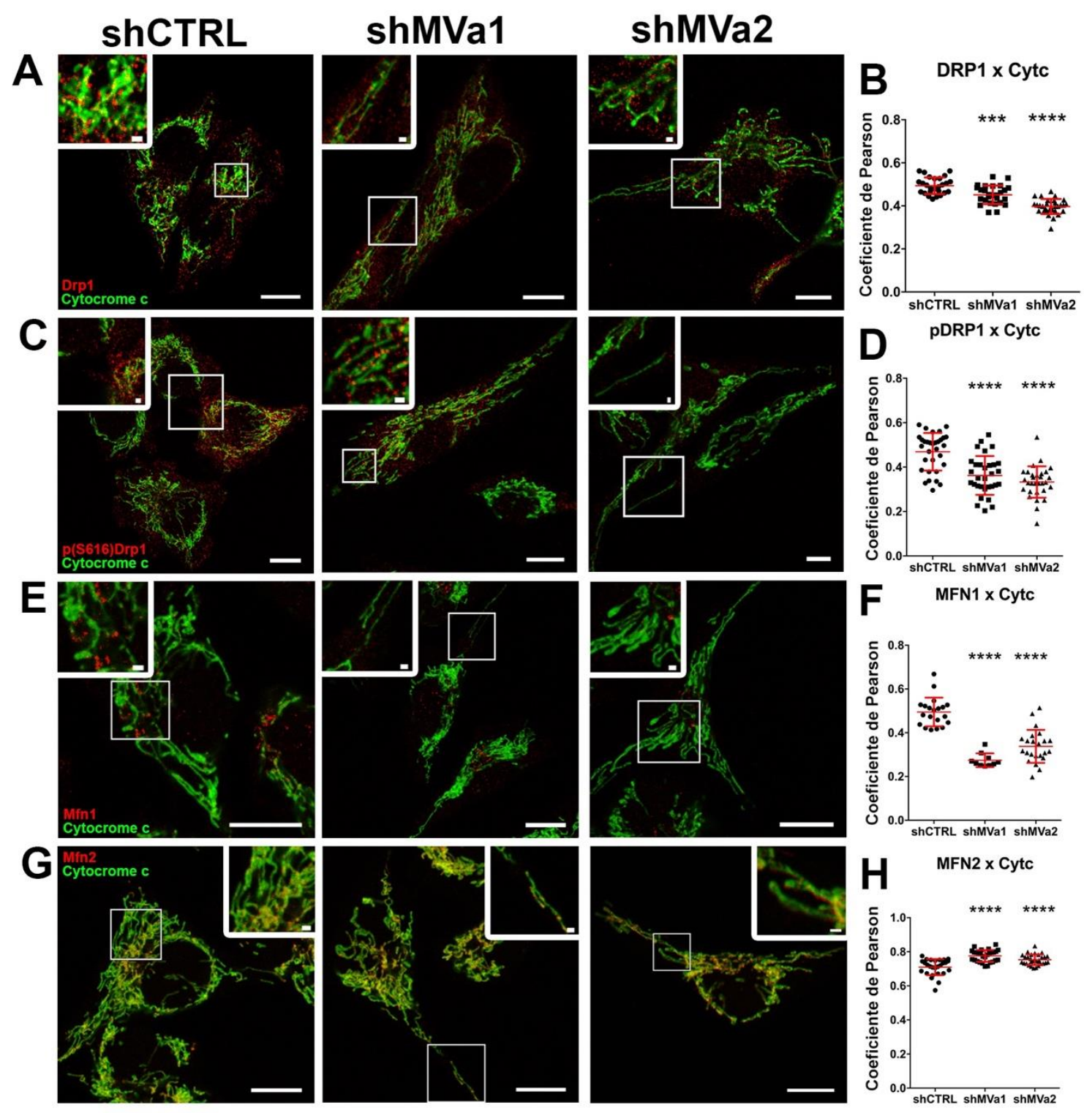

Figura 25. O silenciamento da miosina-Va altera a localização de proteínas relacionadas à dinâmica mitocondrial. Imagens confocais de células A375 silenciadas para miosina-Va A375 (shMVa1 e shMVa2) e controle (shCTRL) mostrando a rede mitocondrial imunomarcada com anticorpo anti-citocromo c (verde) e anticorpos contra A. Drp1, C. p(S616)Drp1, E. Mfn1, e G. Mfn2 em vermelho. Coeficiente de correlação de Pearson mostrando a colocalização de B. Drp1, D. p(S616)Drp1, F. Mfn1, e H. Mfn2 com a rede mitocondrial. Os dados comparam as células silenciadas miosina shMVa1 e shMVa2 com as células controle (shCTRL). One-way ANOVA, $\mathrm{n} \geq 30$ células por condição, 1 experimento. Dados são média $\pm \mathrm{DP}, * * \mathrm{P}<0,001 \mathrm{e} * * * \mathrm{P}<0,0005$, **** $\mathrm{P}<0,0001$. 


\subsection{A miosina-Va se localiza nos pontos de fissão mitocondrial}

As alterações morfológicas que observamos na rede mitocondrial são condizentes com um possível papel da miosina-Va na dinâmica mitocondrial. Para investigarmos isso, inicialmente nós nos perguntamos se a miosina-Va se colocalizava temporoespacialmente com os eventos de fissão mitocondrial. Para responder isso, nós co-expressamos um construto contendo a miosina-Va inteira com tag GFP (MVa-FL-GFP) e coramos as células com MitoTracker para realizarmos experimentos de timelapse. Desta vez, as células utilizadas foram as U2OS, e um microscópio Airyscan de super-resolução foi utilizado para monitorar a dinâmica mitocondrial (Figura 26, Filme Suplementar 2 e 3). A partir destes dados, foi possível observar que 58\% dos eventos de fissão contados tinham acúmulo da miosina-Va (Figura 26C), e que a miosina-Va frequentemente se localizava nas pontas das mitocôndrias "filhas" (Figura 26A e 26B). Também induzimos a fissão mitocondrial através do tratamento das células com ionomicina, que resulta na liberação dos estoques intracelulares de cálcio que provém principalmente dos estoques do RE e o que, por sua vez, estimula a fissão mitocondrial. Após o tratamento com ionomicina, nós observamos um aumento significativo nos eventos de fissão contendo miosina-Va, que estava presente em $\sim 74 \%$ dos eventos de fissão contados (Figura 26C).

Como vimos que a mitoSpire1 é responsável pelo recrutamento da miosina-Va para a MME, mas tendo em vista que a falta da mitoSpire1 não altera a colocalização da miosina-Va na rede mitocondrial (Figura 10), nós também nos perguntando se a mitoSpire1 seria necessária para a localização da miosina-Va nos pontos de fissão mitocondrial. Para isso, também analisamos a localização do construto a cauda inteira com tag GFP da miosina-Va (MVa-FTGFP) nas células U2OS WT e mitoMitoSpire1 KOs, usando um microscópio Airyscan de superresolução para monitorar a dinâmica mitocondrial através de experimentos de timelapse (Figura 27, Filme Suplementar 4 e 5). Estes dados nos permitiram observar que a cauda inteira da miosina-Va está presente em $61 \%$ do total de eventos de fissão mitocondriais contados nas células U2OS WT, e em apenas 36\% do total de eventos de fissão mitocondriais contados nas células U2OS mitoSpire1 KO. Consistentemente, quando comparamos a presença do construto contendo cauda inteira da miosina-Va com o construto contendo a miosina-Va inteira nos locais de fissão mitocondrial, podemos notar que a presença de ambos os construtos é muito semelhante, sendo 58\% para MVa-FL-GFP e 61\% para MVa-FL-GFP (Figura 26 e Figura 27). 

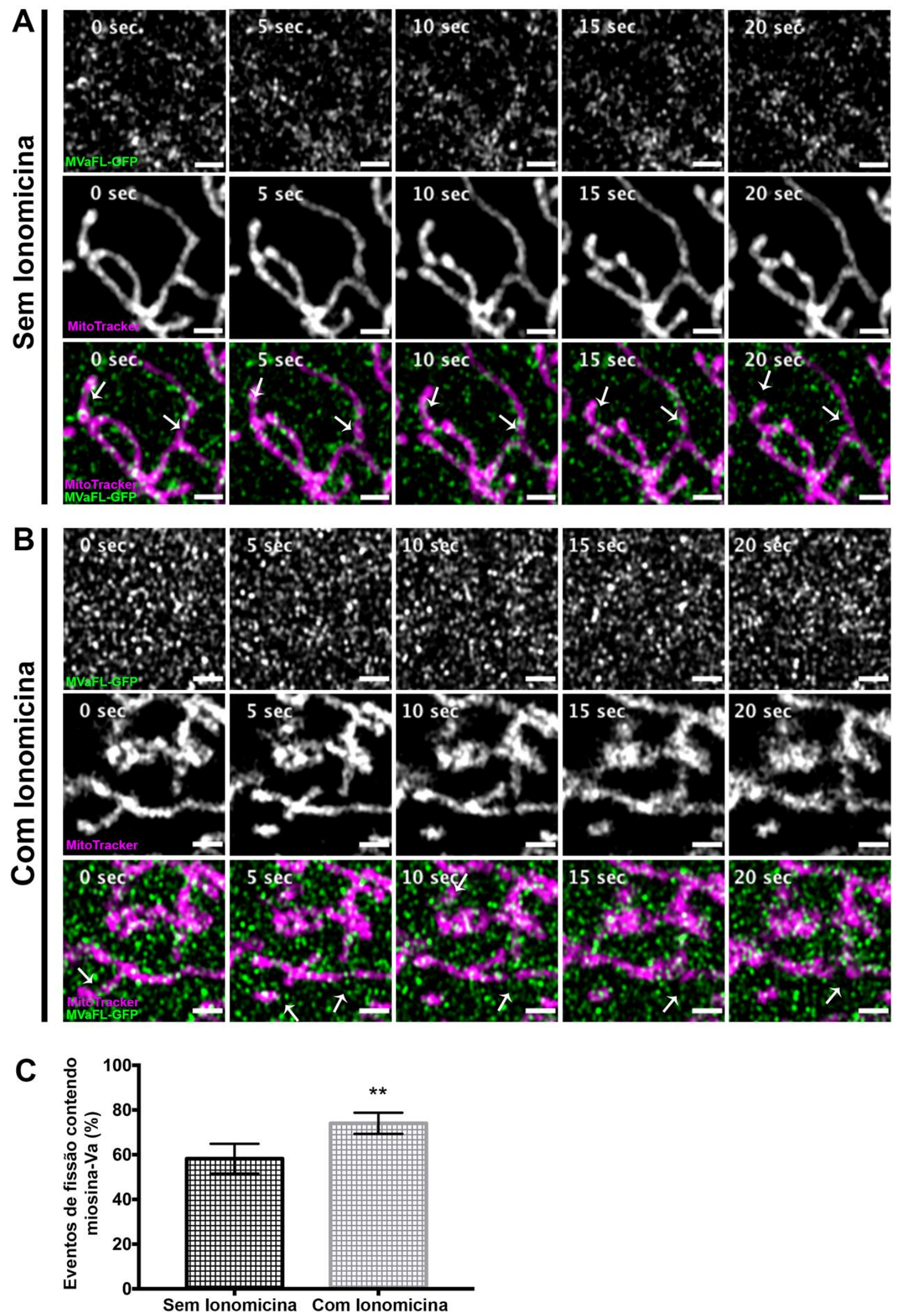

Figura 26. A miosina-Va localiza-se nos pontos de fissão mitocondrial. A. Imagens de vídeo-microscopia de super-resolução Airscan de células U2OS mostrando a localização de MVaFL-GFP juntamente com a mitocôndria corada com MitoTracker DeepRed em uma condição de controle e B. tratada com ionomicina. C. Quantificação dos eventos de fissão que a miosina-Va estava presente, tanto na constrição da mitocôndria quanto nas pontas das 
mitocôndrias recém-formadas. Os eventos de fissão foram contados em pelo menos 5 vídeos para cada condição. Teste $\mathrm{t}$ não pareado, os dados são a média $\pm \mathrm{DP}, * * \mathrm{P}<0,001$. Barra de escala: $1 \mu \mathrm{m}$.
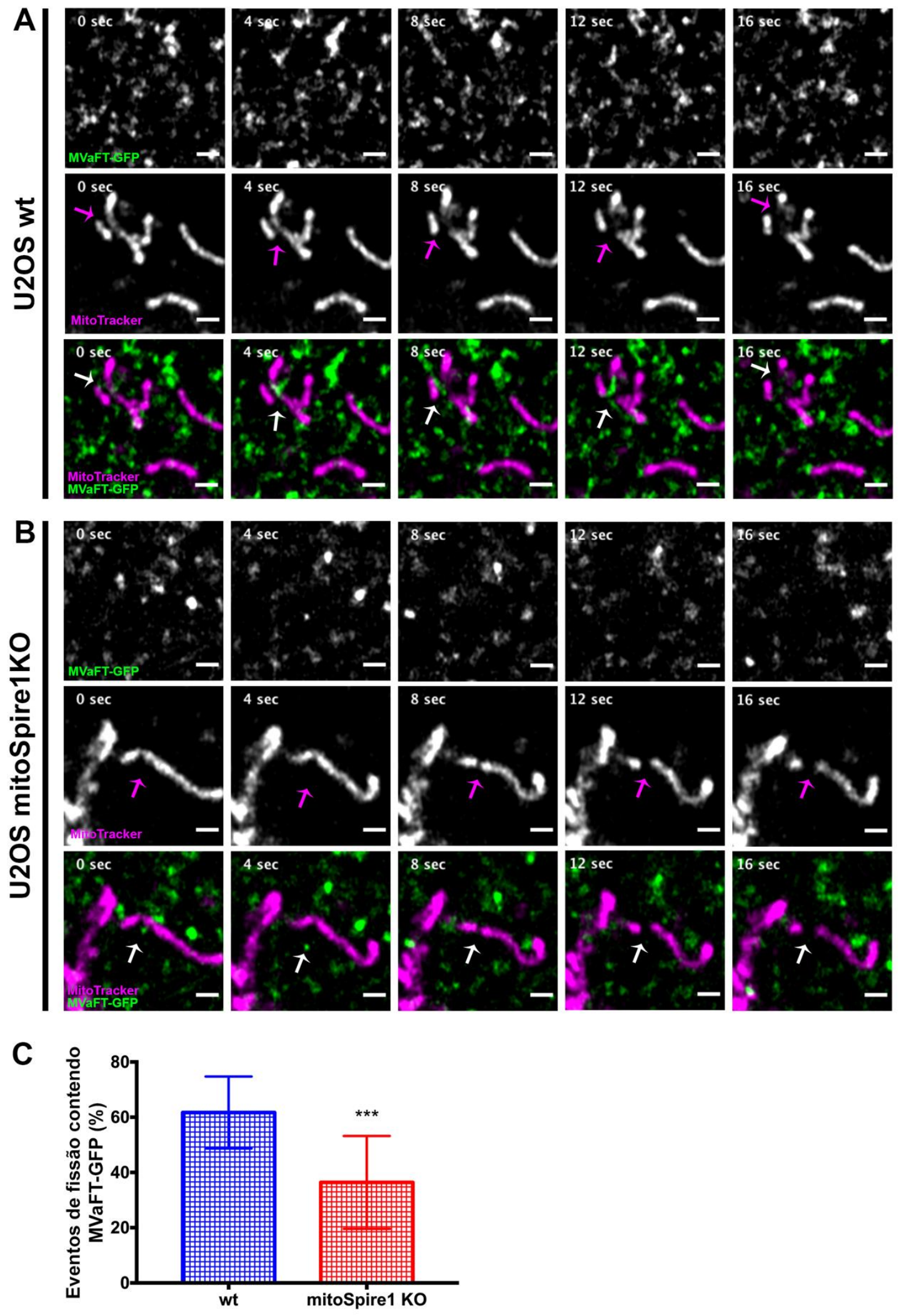

Figura 27. O nocaute da mitoSpire1 diminui a localização da cauda inteira da miosina-Va nos locais de fissão mitocondrial. Imagens de vídeo-microscopia de super-resolução Aryscan de A. U20S WT e B. U20S 
mitoSpire1KO. As células foram coradas com MitoTracker DeepRed (magenta) e transfectadas com um construto da cauda inteira da miosina-Va (MVaFT-GFP, verde). As setas magentas e brancas indicam um local de fissão e a localização de MVaFT-GFP relacionada a esse local de fissão. C. Quantificação dos eventos de fissão contendo MVaFT-GFP nos locais de constrição mitocondrial e pontas de mitocôndrias recém-formadas. Os dados são média \pm DP. Teste $t$ não pareado (células $n=12$ para cada condição, 2 experimentos diferentes).

\subsection{A miosina-Va se localiza nos pontos de fissão mitocondrial juntamente com Drp1}

Tendo em vista a possível interação da miosina-Va com a Drp1 demonstrada pelo nosso experimento de cromatografia de afinidade seguida de espectrometria de massas (Tabela Suplementar 1), nós decidimos investigar a colocalização da miosina-Va endógena com a Drp1 nos pontos de fissão mitocondrial. Para isso, nós imunomarcamos células U2OS com anticorpos contra a miosina-Va, Drp1 e HSP60 (marcador mitocondrial), e utilizamos um microscópio de super-resolução AiryScan para aquisição das imagens. Observamos que uma fração significativa da miosina-Va se localiza muitas vezes adjacente a Drp1 nas extremidades das mitocôndrias "filhas". Isso sugere que, embora essas duas proteínas possam não interagir diretamente, elas se localizam em locais de fissão ativa (Figura 28A). Indo além, nós tratamos as células com ionomicina com intuito de estimular a fissão mitocondrial, e em seguida, repetimos a imunomarcação para miosina-Va, Drp1 e HSP60. Como esperado, a indução da fissão mitocondrial aumentou significativamente a localização de Drp1 nas mitocôndrias em aproximadamente 1,4x (de 43,5\% para 60,6\%) nas células tratadas com ionomicina (Figura 28B). Corroborando com a nossa hipótese de que a miosina-Va desempenha um papel na fissão mitocondrial, a localização da miosina-Va nas mitocôndrias aumentou em 1,3x (de 37,3\% para 48,3\%) nas células tratadas com ionomicina (Figura 28C).

Além disso, também analisamos se mitoSpire1 seria necessária para a interação entre miosina-Va e Drp1, ou se a depleção da mitoMitoSpire1 causaria uma diminuição da localização de Drp1 nos pontos de fissão mitocondrial. Para isso, nós transfectamos os construtos MVaFT-GFP e Drp1-mCherry em células U2OS WT e mitoMitoSpire1 KO, e utilizamos um microscópio Airyscan de super-resolução para monitorar a dinâmica mitocondrial através de experimentos de timelapse. Observamos que Drp1-mCherry estava presente em todos os eventos de fissão mitocondrial contados (Figura 29A e 29B, Filme Suplementar 6 e 7), tanto em células U2OS WT quanto em células mitoMitoSpire1 KO. Já o construto MVaFT-GFP estava presente em cerca de $60 \%$ de todos os eventos de fissão mitocondrial contados de células U20S WT (Figura 29A e 29B), como já foi observado em outros dados (Figura 27). E estava presente em apenas cerca de $35 \%$ dos eventos de fissão 
contados em células U20S mitoSpire1KO, mostrando novamente que a falta de mitoSpire1 leva a uma presença diminuída de MVaFT-GFP nos locais de fissão mitocondrial. No entanto, mão encontramos nenhuma evidência significativa de que a depleção da mitoSpire1 altera a localização de Drp1 nos pontos de fissão mitocondrial.
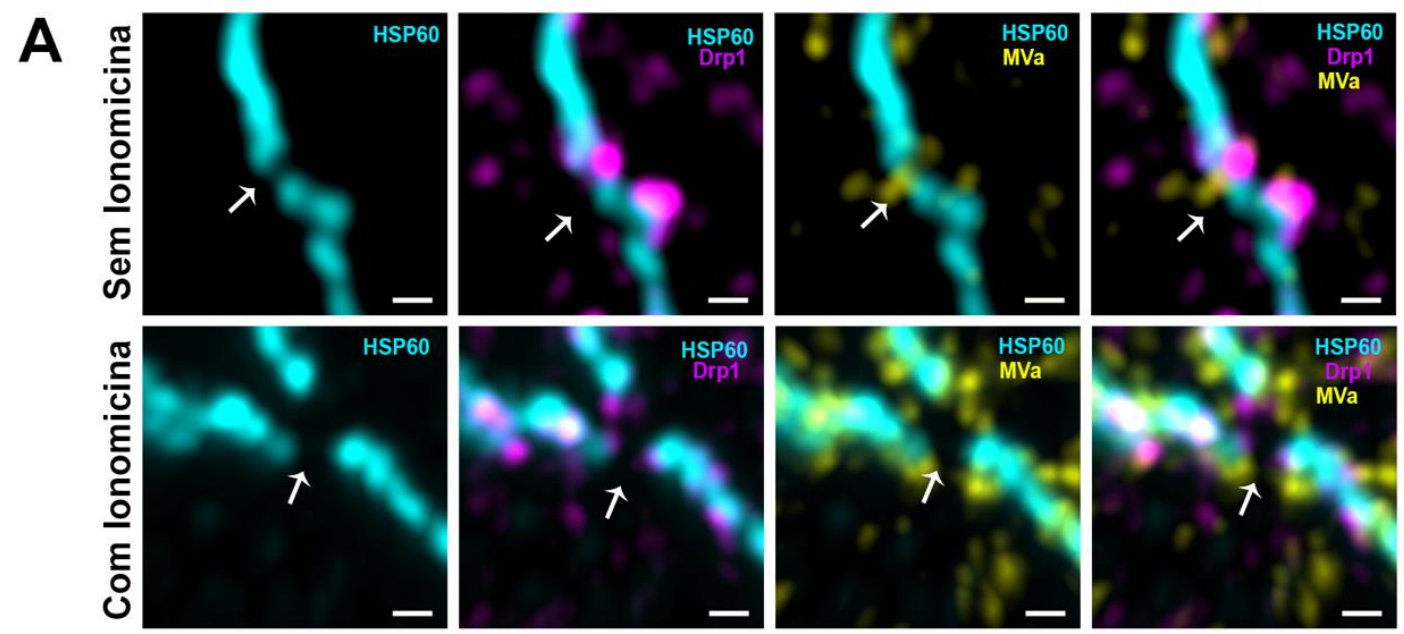

B

$$
\begin{aligned}
& \text { Drp1 x Mitocôndria } \\
& \text { Colocalização }
\end{aligned}
$$
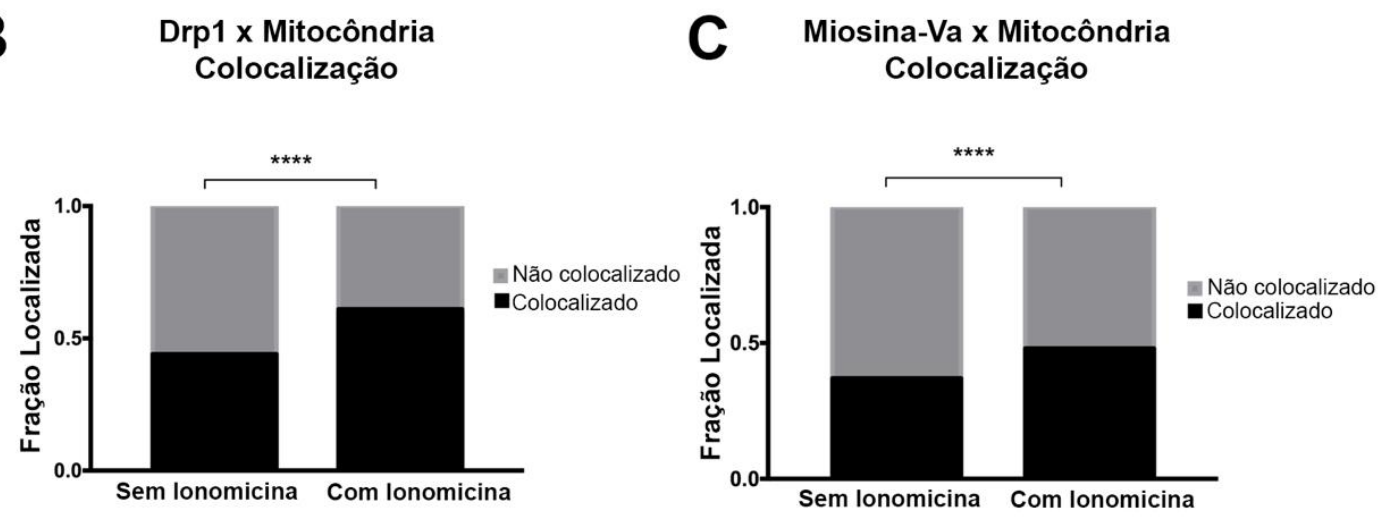

Figura 28. A miosina-Va se localiza juntamente com DRP1 em locais de fissão mitocondrial. A. Imagens de super-resolução Airscan de células U2OS mostrando a imunomarcação da rede mitocondrial com anti-Hsp60 (ciano), a miosina-Va endógena (amarelo), e Drp1 (magenta), antes do tratamento com ionomicina (painéis superiores) e após ionomicina tratamento (painéis inferiores). Barra de escala: $2 \mu \mathrm{m}$. Os gráficos são representativos da B. colocalização de Drp1 com a rede mitocondrial e da C. colocalização da miosina-Va com a rede mitocondrial com e sem a adição de $4 \mu \mathrm{M}$ de ionomicina. 2-way ANOVA, **** $\mathrm{P}<0,0001$. 

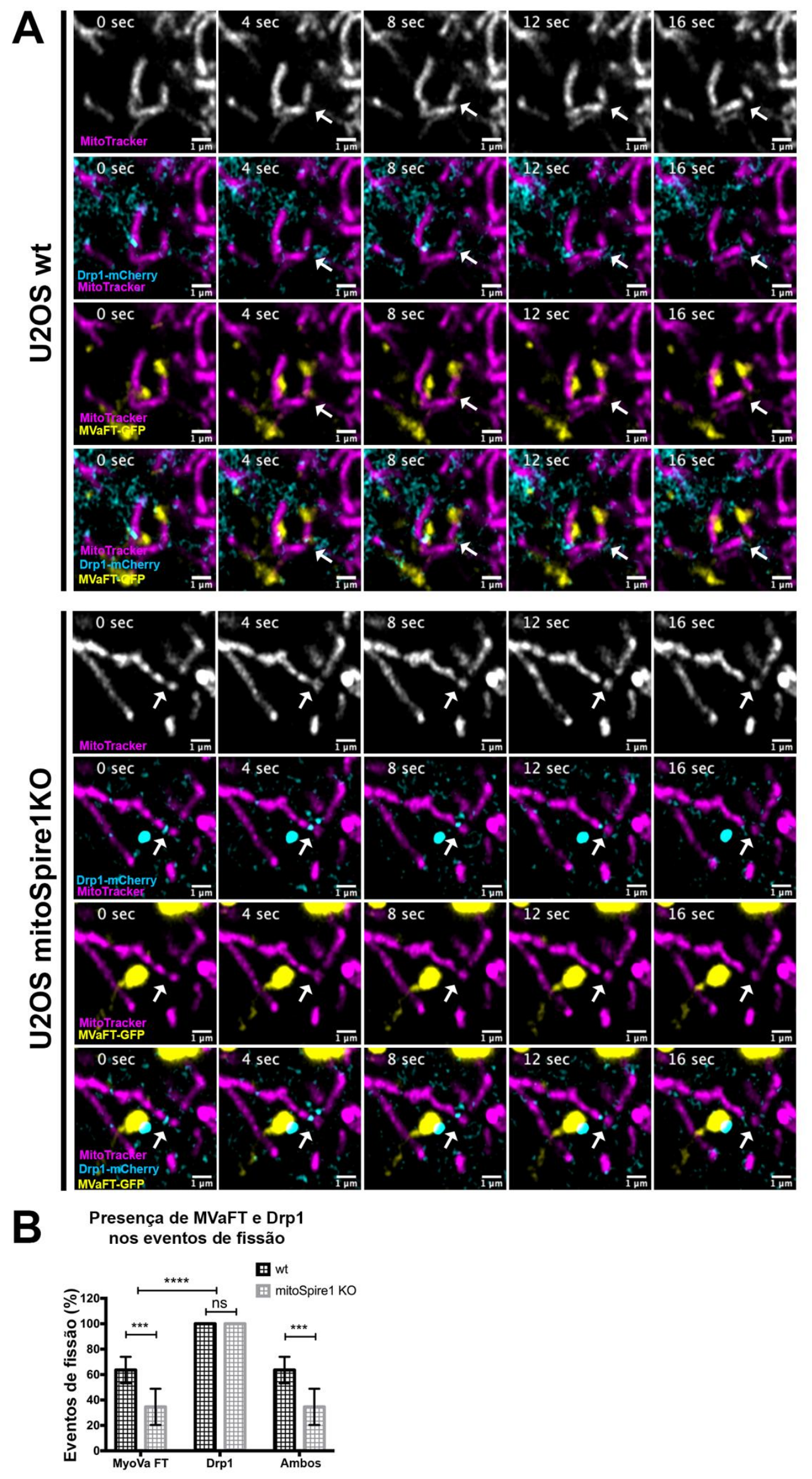
Figura 29. O nocaute da mitoSpire1 diminui a localização da cauda inteira da miosina-Va, mas não de Drp1, nos locais de fissão mitocondrial A. Imagens de vídeo-microscopia de super-resolução Aryscan de células U20S WT e U20S mitoSpire1KO. As células foram coradas com MitoTracker DeepRed (magenta) e transfectadas com um construto da cauda inteira da miosina-Va (MVaFT-GFP, amarelo), e Drp1 (Drp1-mCherry, ciano). As setas brancas indicam um local de fissão e a localização de MVaFT-GFP e Drp1-mCherry relacionadas a esse local de fissão. B. Quantificação dos eventos de fissão contendo MVaFT-GFP, Drp1-mCherry e ambos MVaFT-GFP e Drp1-mCherry nos locais de constrição mitocondrial e pontas de mitocôndrias recém-formadas. Os dados são média \pm DP. 2-way ANOVA, *** $\mathrm{P}<0,0002$ ( $\mathrm{n} \geq 8$ células para cada condição).

\subsection{A miosina-Va se localiza nos pontos de fissão mitocondrial juntamente com Rab11a}

Nós desenvolvemos a hipótese de que outra proteína poderia mediar a interação entre miosina-Va e mitoSpire1. Levando em consideração que as proteínas Rabs são conhecidas por interagirem com a miosina-Va (Lindsay et al., 2013), e até mediando a interação dela com outras proteínas adaptadoras (Strom et al., 2002). Considerando dados anteriores da literatura (Pfender et al., 2011; Pylypenko et al., 2016) decidimos olhar para a dinâmica e colocalização da Rab11a em torno da rede mitocondrial juntamente com a miosina-Va. Para isso, nós tranfectamos os construtos MVaFT-GFP e Rab11-mApple em células U2OS WT e mitoMitoSpire1 KO e utilizamos um microscópio Airyscan de super-resolução para aquisição das imagens e monitoramento da dinâmica mitocondrial através de experimentos de timelapse. Observamos que a colocalização entre MVaFT-GFP e Rab11-mApple é alta (Figura 30A e 30B), e que ambas as proteínas possuem uma dinâmica muito semelhante nas células. Também observamos que Rab11a também possui um grau semelhante de colocalização com a rede mitocondrial quando comparado ao grau de colocalização de MVaFT-GFP com a rede mitocondrial (Figura 30C e Figura 10). No entanto, não encontramos diferenças na colocalização, tanto entre Rab1 1 a e MVa-FT-GFP, quanto entre Rab11a e MitoTracker, quando comparamos as células U2OS WT e U2OS mitoSpire1KO (Figura 30).

Também analisamos a presença da Rab11a nos eventos de fissão mitocondrial. Curiosamente, cada evento de fissão com a presença de MVaFT-GFP, também teve a presença de Rab11-mApple (Figura 31A e 31B, Filme Suplementar 8 e 9). Além disso, Rab11-mApple foi mais frequente nos eventos de fissão mitocondrial do que MVaFT-GFP, possivelmente devido à sua expressão mais abundante. Observamos também que a depleção da mitoSpire1 causou uma redução significativa da presença de Rab11-mCherry nos eventos de fissão mitocondrial, como fez para MVaFT-GFP (Figura 27). Em conjunto estes dados sugerem que miosina-Va, Rab11a e mitoSpire1 podem formar um complexo proteico envolvido na fissão mitocondrial. 
A

A

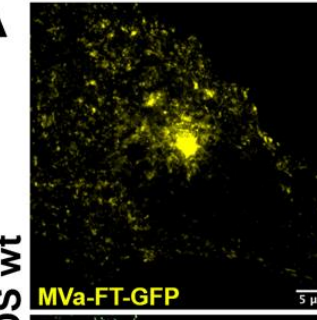

กิ
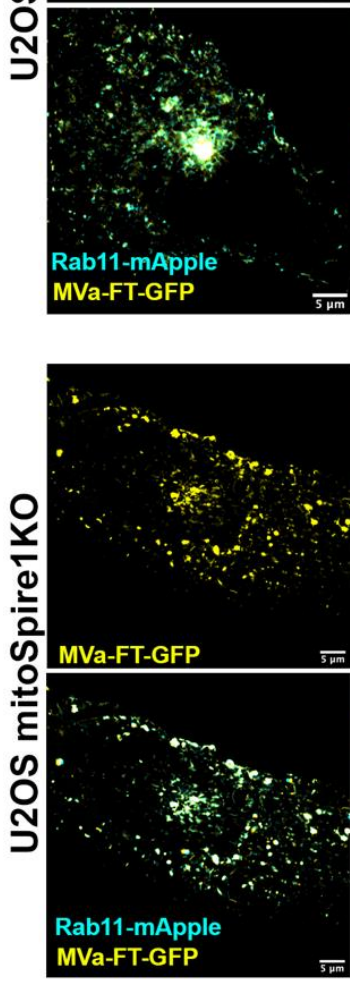

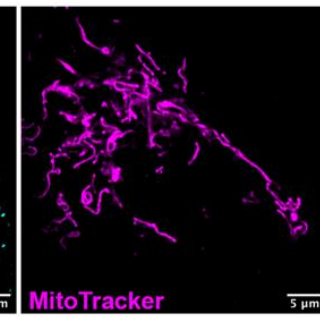

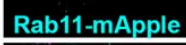
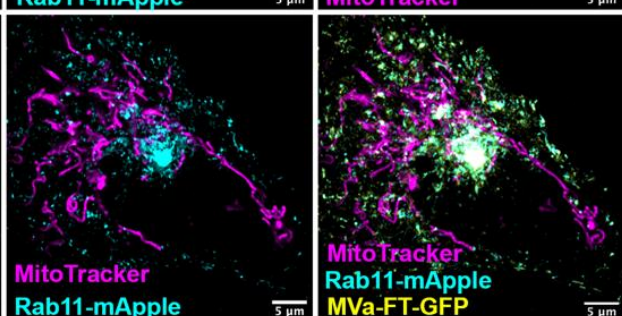

B

Rab11 x MVaFT-GFP

Colocalização

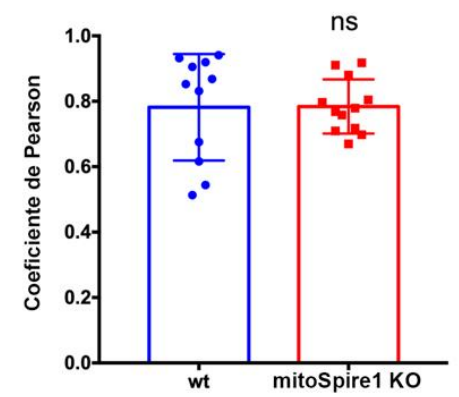

C Mitocôndria x Rab11 Colocalização
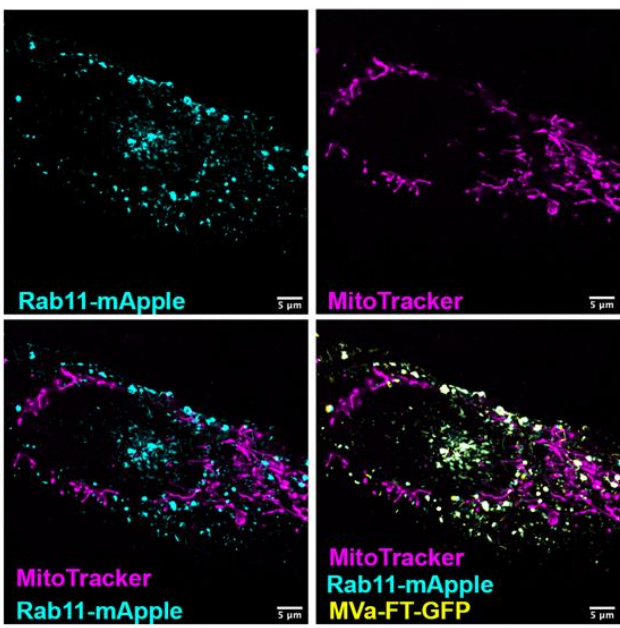

Figura 30. O nocaute de mitoSpire1 não interfere na colocalização entre Rab11a e a cauda da miosina-Va ou na localização de Rab11a nas mitocôndrias. A. Imagens de microscopia de super-resolução Aryscan de células U20S WT e U20S mitoSpire1KO. As células foram coradas com MitoTracker DeepRed (magenta) e transfectadas com um construto da cauda inteira da miosina-Va (MVaFT-GFP, amarelo), e Rab11a (Rab11mApple, em ciano). B. Coeficiente de correlação de Pearson mostrando a colocalização de Rab11a com a cauda inteira da miosina-Va em células U20S WT e mitoSpire1 KO. C. Coeficiente de correlação de Pearson mostrando a colocalização de Rab11a com a rede mitocondrial em células U20S WT e mitoSpire1 KO. Os dados são média \pm DP. Teste $t$ não pareado (células $n \geq 20$ para cada condição). 

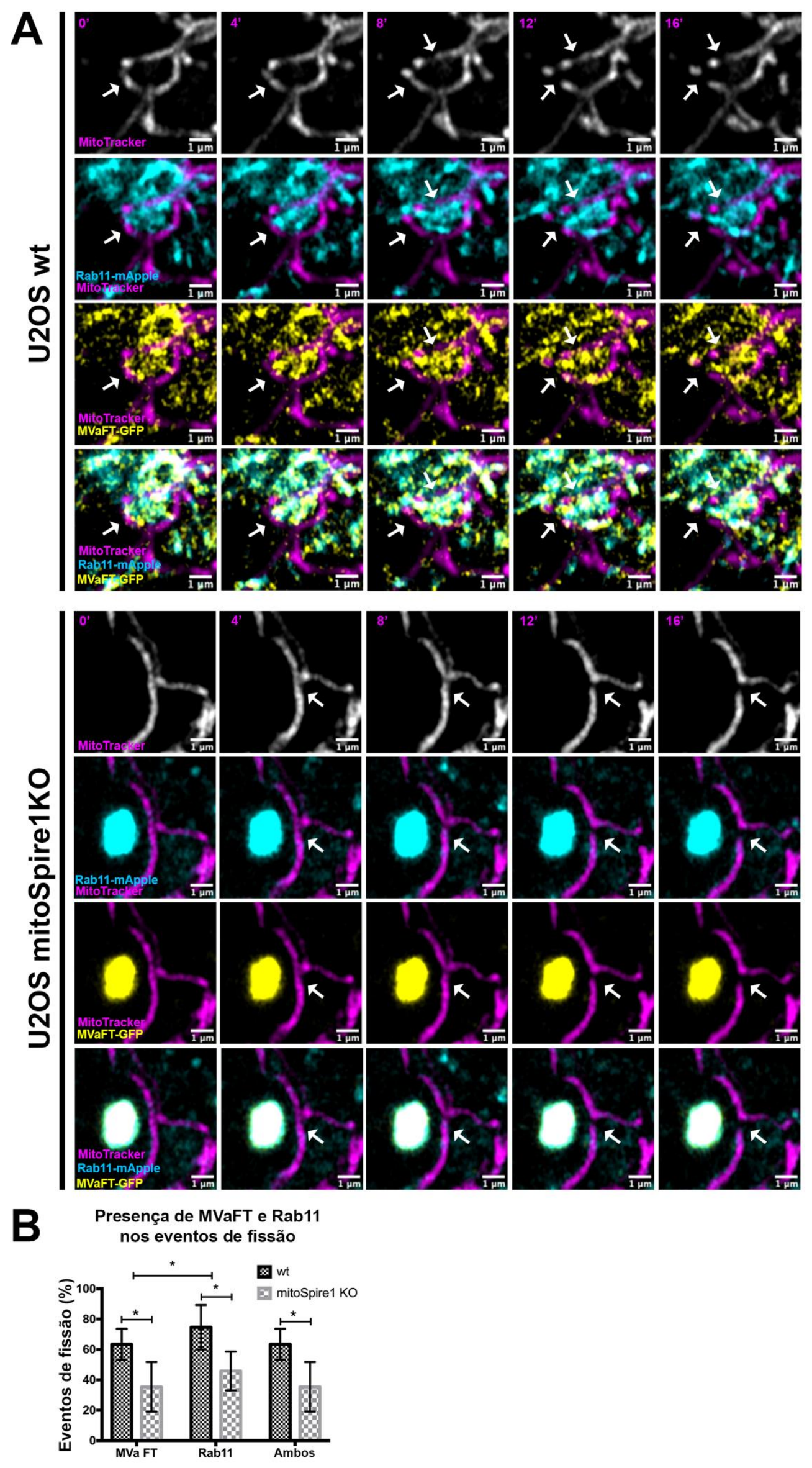
Figura 31. O nocaute da mitoSpire1 diminui a localização da Rab11a e da cauda inteira da miosina-Va nos locais de fissão mitocondriais. A. Imagens de vídeo-microscopia de super-resolução Aryscan de células U20S WT e U20S mitoSpire1KO. As células foram coradas com MitoTracker DeepRed (magenta) e transfectadas com um construto da cauda inteira da miosina-Va (MVaFT-GFP, amarelo), e Rab11a (Rab11-mApple, em ciano). As setas brancas indicam um local de fissão e a localização de MVaFT-GFP e Rab11-mApple relacionada a esse local de fissão. B. Quantificação dos eventos de fissão contendo MVaFT-GFP, Rab11-mApple e ambos MVaFT-GFP e Rab11-mApple nos locais de constrição mitocondrial e pontas de mitocôndrias recém-formadas. Os dados são média \pm DP. 2-way ANOVA, * $\mathrm{P}<0,03$ (células $\mathrm{n}=10$ para cada condição).

\subsection{A depleção da miosina-Va leva a uma diminuição dos eventos de fissão mitocondrial}

Com o objetivo de entendermos melhor se o alongamento mitocondrial causado pela falta da miosina-Va era realmente devido à um desequilíbrio da dinâmica mitocondrial, nós analisamos timelapses das células silenciadas para miosina-Va (shMVa2) comparadas com células controle (shCTRL) coradas com MitoTracker. A partir da observação dos timelapses nós descobrimos que as células silenciadas para miosina-Va exibiram um número reduzido de eventos de fissão mitocondrial (Figura 32A e Filme Suplementar 10 e 11). Para isso, 10 timelapses de cada condição foram observados, e os eventos totais de fissão de cada condição foram contados e comparados. O mesmo foi feito nas células $\mathrm{KO}$ para miosina-Va, elas também foram coradas com MitoTracker e utilizadas para experimentos de timelapses. Concordante com o visto nas células silenciadas, as células KO também apresentaram um número total de eventos de fissão reduzidos, quando comparados com células controle (Figura 32B e Supl. Filme 12 e 13). A partir deste experimento, podemos inferir com mais propriedade que a miosina-Va é necessária para manutenção dos eventos de fissão, já que a sua falta leva à uma diminuição deste evento. 

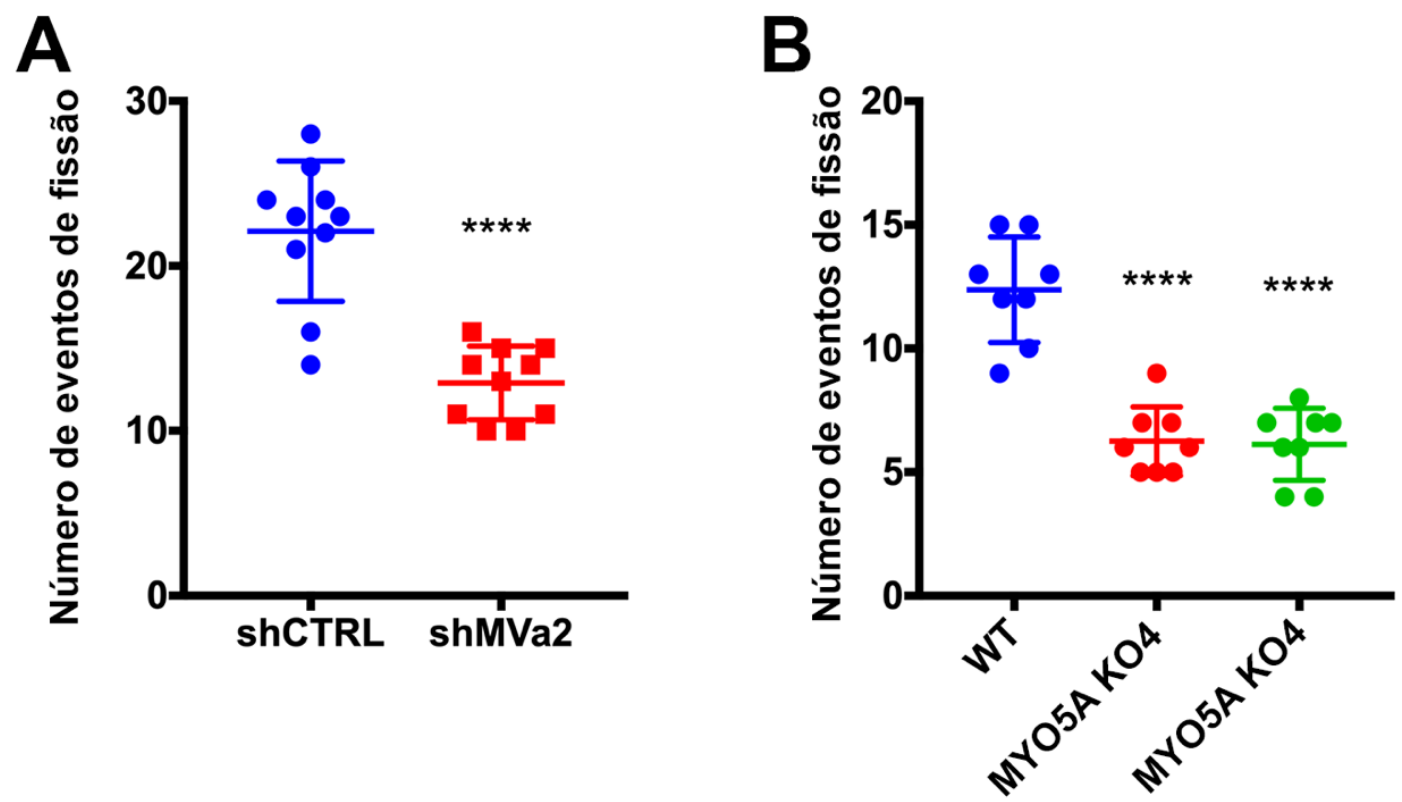

Figura 32. A depleção da miosina-Va leva a uma diminuição dos eventos de fissão mitocondrial. A. Número de eventos de fissão de células A375 silenciadas miosina-Va (shMVa2) em comparação com células de controle (shCTRL), vídeos representativos são mostrados no material suplementar. Os dados são média \pm DP Teste t não pareado, $* * * * \mathrm{P}<0,0001$ ( $\mathrm{n}=10$ células para cada condição). B. Número de eventos de fissão de células A375 nocauteadas para miosina-Va (MYO5AKO4 e MYO5A KO5) em comparação com células WT, vídeos representativos são mostrados no material suplementar. Os dados são média \pm DP One-way anova, **** $\mathrm{P}<0,0001$ ( $\mathrm{n}=10$ células para cada condição).

\subsection{A depleção da miosina-Va leva a menores taxas de consumo de oxigênio}

Tendo em vista que alterações da morfologia mitocondrial comumente se traduzem em alterações metabólicas (Mishra and Chan, 2016), nós decidimos analisar se a depleção da miosina-Va causava alguma alteração nas taxas de consumo de oxigênio (OCR) das células, utilizando o analisador Seahorse. Para isso, nós utilizamos as células A375 WT e A375 MYO5A $\mathrm{KO}$, e os fibroblastos nulos para miosina-Va e os fibroblastos normais como controle. As taxas de OCR nas células A375 MYO5A KO foram menores do que nas células WT (Figura 33A e 33B). Consistentemente, as taxas de OCR dos fibroblastos humanos nulos para miosina-Va também foram mais baixas quando comparadas aos fibroblastos normais (Figura 33C e 33D). As taxas de OCR mais baixas observadas também refletem em menores níveis de produção de ATP ligado ao consumo de oxigênio por essas células (Figura 33E e 33F). 

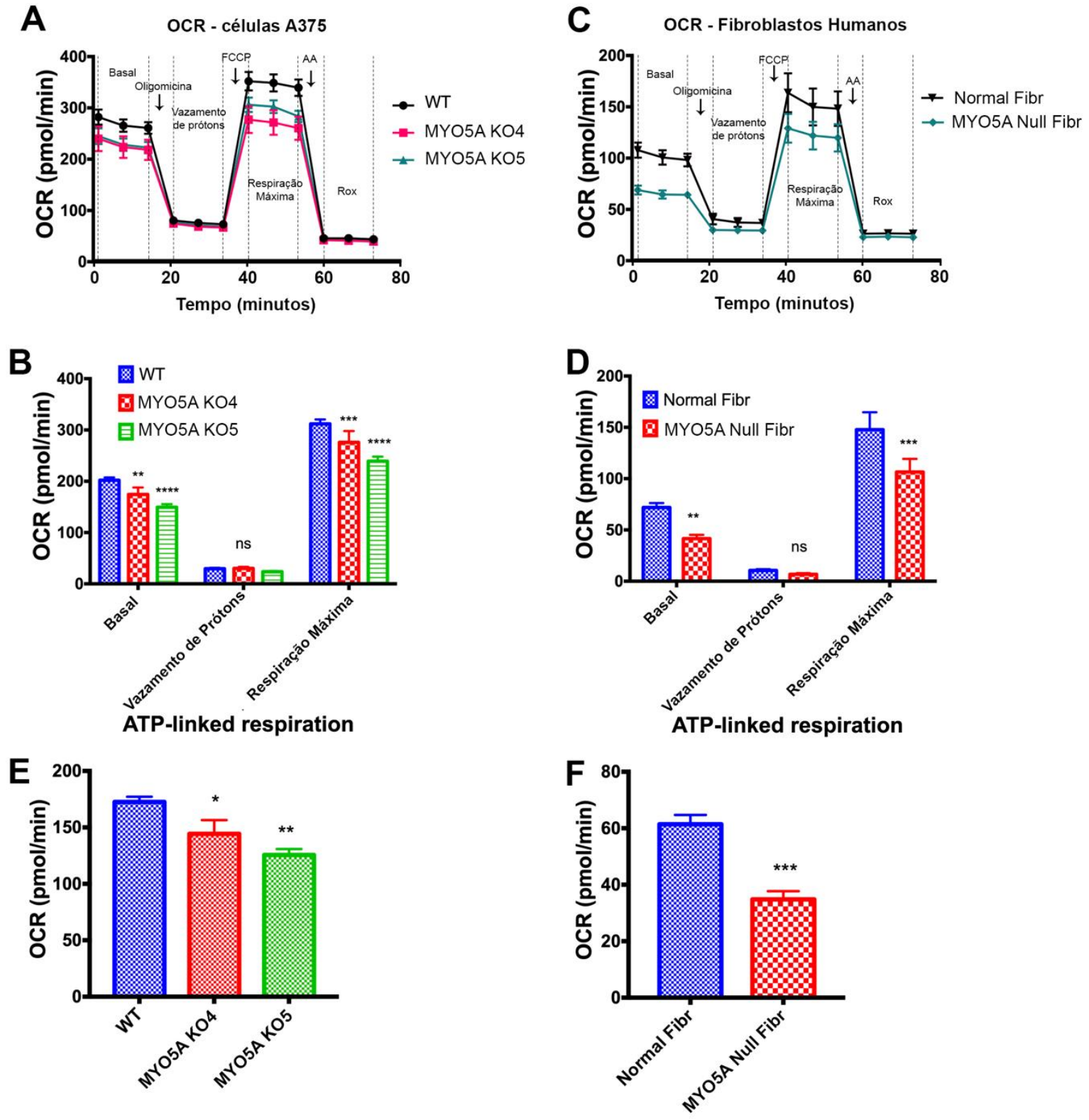

Figura 33. As células depletadas para miosina-Va apresentam menores taxas de consumo de oxigênio (OCR). Traços representativos de oxígrafo de alta resolução (Seahorse - Cell Mito Stress Kit) mostrando a atividade respiratória das células A. A375 WT e A375 MYO5A KO, e de C. Fibroblastos humanos normais e fibroblastos humanos nulos para miosina-Va. As setas indicam a adição de $1,5 \mu \mathrm{g} / \mathrm{mL}$ de oligomicina, $1 \mu \mathrm{M}$ de FCCP e $0,5 \mu \mathrm{g} / \mathrm{mL}$ de antimicina A (AA) usados para determinar os estados respiratórios: basal, vazamento de prótons, respiração máxima e respiração residual (Rox). Os gráficos de barras mostram a média dos estados: basal, vazamento de prótons e respiração máxima para as células B. A375 WT e A375 MYO5A KO e D. Fibroblastos humanos normais e fibroblastos humanos nulos para miosina-Va. Os dados são média \pm DP. Os dados foram analisados usando 2-way ANOVA, *** $\mathrm{P}<0,0002$, **** $\mathrm{P}<0,0001$ ( $\mathrm{n}=3$ experimentos independentes).

Devido a esse motivo, nós decidimos também analisar o conteúdo das proteínas constituintes dos complexos da cadeia respiratória mitocondrial através de um western blot. Observamos que não há diferenças significativas nestas proteínas quando comparamos células A375 MYO5AKO e células controle (Figura 34). Portanto, podemos concluir que as mudanças 
observadas nas taxas de OCR das células nulas para miosina-Va não são devidos à uma menor expressão das proteínas componentes da cadeia respiratória, e provavelmente são devidas a outros efeitos globais da célula.

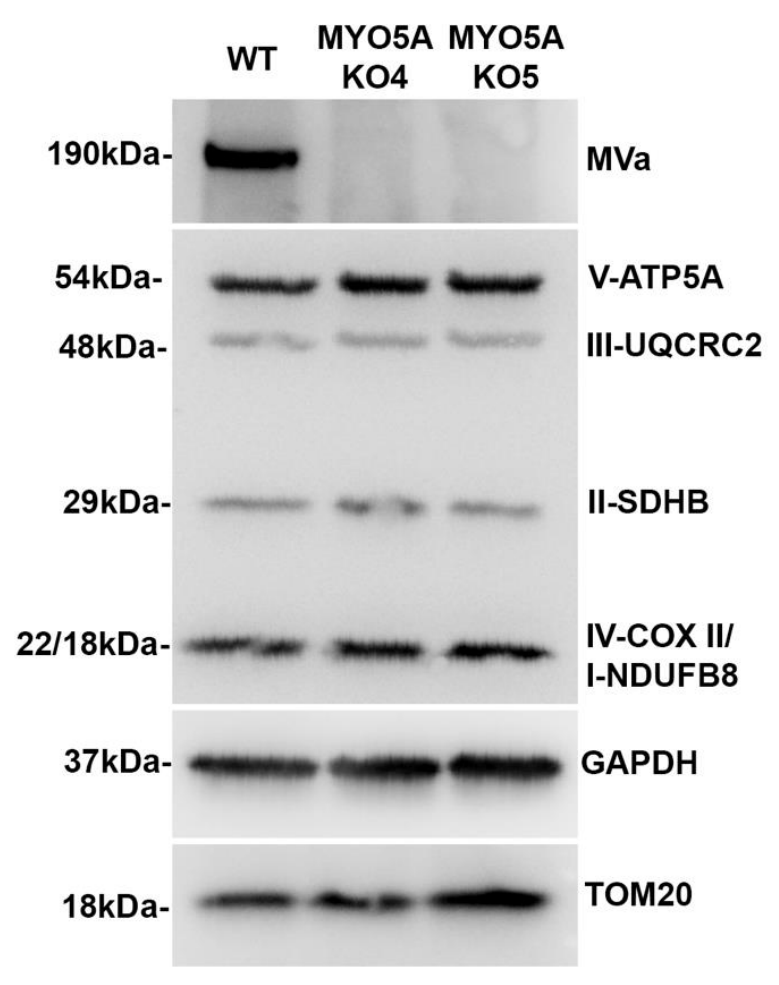

Figura 34. O nocaute da miosina-Va não altera as proteínas da cadeira respiratória mitocondrial. Western blots contendo lisado total de células A375 WT e MYO5A KO marcados com anticorpos anti-Cabeça-Miosina-Va, anti-TOM20, anti-GAPDH como normalizador de carga proteica, e com um coquetel anti-OXPHOS, que marca as proteínas ATP5A (complexo V), UQCRC2 (Complexo III), SDHB (Complexo II), COXII (Complexo IV) e NDUFB8 Complexo I), respectivamente, de acordo com o peso molecular de cada uma.

\subsection{As células nocaute para miosina-Va não apresentam diferenças nos níveis de acidificação extracelular}

Ainda investigando as diferenças metabólicas geradas pela deleção da miosina-Va nas células A375, nós analisamos os níveis de acidificação extracelular (ECAR) das células A375 MYO5AKO e A375 WT utilizando também o analisador Seahorse (Figura 35A). A conversão de glicose para piruvato no citoplasma das células libera lactato, o que resulta na liberação de prótons para o meio extracelular, gerando uma acidificação. Este experimento mede a acidificação do meio extracelular das células, e uma das principais fontes dessa acidificação provém do metabolismo da glicose. Observamos que não há diferenças dos níveis ECAR das células A375 MYO5AKO quando comparadas com as células controle A375 WT. Analisamos também a captação de glicose (Figura 35B) e a secreção de lactato (Figura 35C) utilizando um 
kit diferente, e obtivemos resultados consistentes. Novamente, não houve diferenças significativas entre as células A375 MYO5AKO e A375 WT.
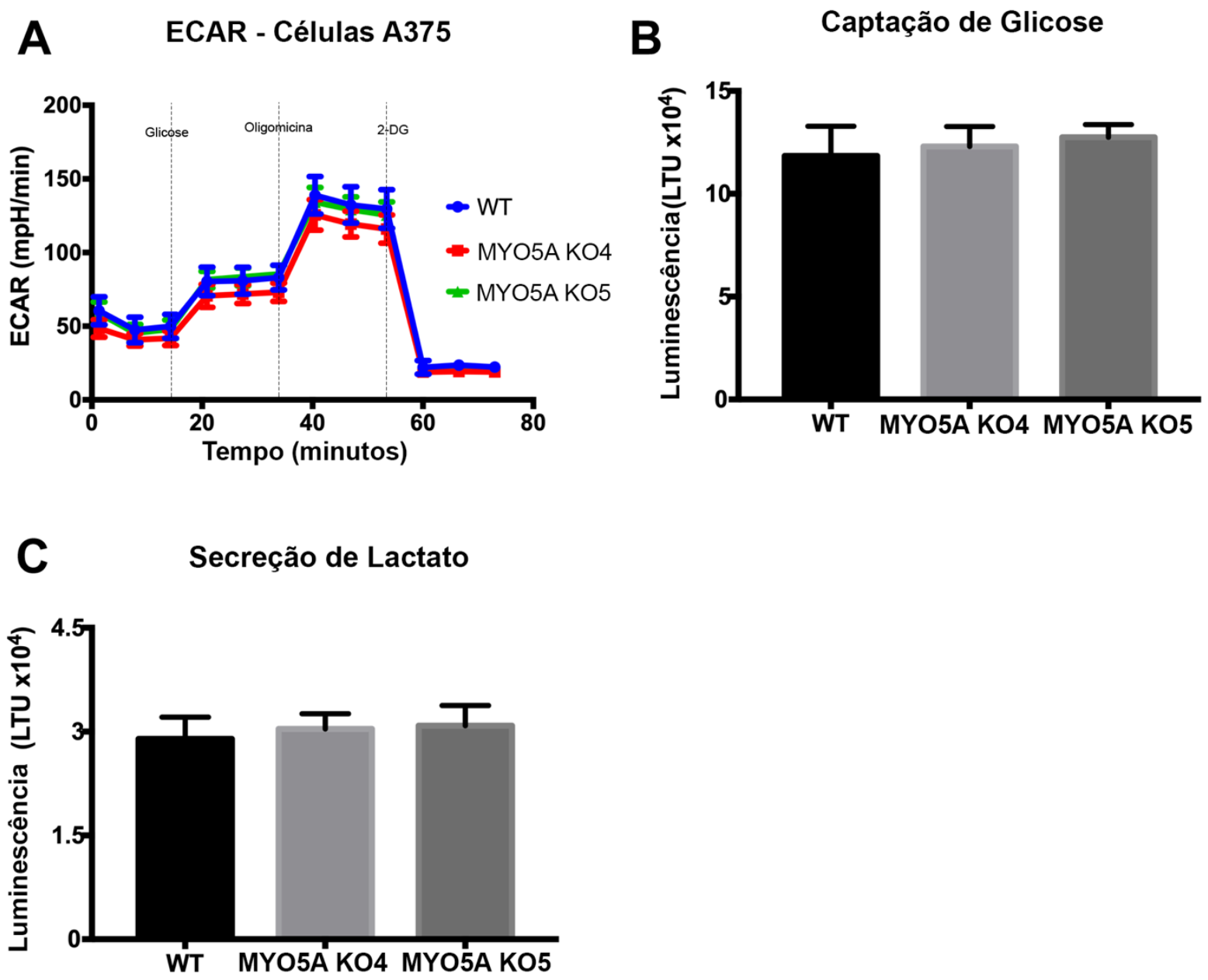

Figura 35. O nocaute da miosina-Va não muda os níveis de acidificação extracelular. A. Níveis de ECAR em células A375 WT e A375 MYO5A KO medidos utilizando o equipamento Seahorse - Glycolysis Stress Test Kit, mostrando o nível de acidificação extracelular. As setas indicam a adição de $10 \mathrm{mM}$ de glicose, $1 \mu \mathrm{M}$ de oligomicina e 50mM de 2-DG. B. Quantificação da captação de glicose, C. quantificação da secreção de lactato em células A375 WT e A375 MYO5A KO. Os valores representam a média \pm D.P. de três experimentos diferentes.

\subsection{A depleção da miosina-Va altera propriedades tumorigênicas das células} A375

Pensando nos efeitos que o nocaute da miosina-Va poderia causar nas propriedades tumorais das células de A375, nós realizamos alguns ensaios funcionais para avaliar esta questão. Observamos que a capacidade proliferativa das células MYO5AKO não foi alterada (Figura 36A), quando comparadas com a proliferação das células controle, durante o tempo de realização do ensaio. Já quando realizamos um ensaio clonogênico, que analisa a capacidade 
que uma célula tem de isoladamente sobreviver e proliferar, e desse modo, gerar colônias; vimos que há uma redução da quantidade de colônias geradas pelas células $M Y O 5 A \mathrm{KO}$, quando comparadas com as células controle (Figura 36B). Para analisar o processo migratório das células, realizamos o ensaio de wound healing no qual avaliamos o fechamento da "ferida", ou seja, a migração das células das bordas em direção ao centro. Observamos na Figura 36C que as células MYO5AKO, principalmente no tempo de 48 horas, foram menos eficientes do que as células controle no fechamento da ferida.

Sendo que a célula A375 possui a mutação BRAFV600E, nós decidimos também acompanhar a viabilidade das células A375 MYO5AKO e A375 WT tratadas com concentrações crescentes de Vemurafenib $(0,001-100 \mu \mathrm{M})$, um inibidor seletivo da proteína mutada BRAFV600E, já utilizado na clínica para tratamento de melanoma. Após 72 horas de tratamento, observamos que as células A375 WT apresentaram um IC50 de $0.1805 \mu \mathrm{M}$, enquanto as células MYO5A KO4 e KO5 apresentaram o IC50 de $0.154 \mu \mathrm{M}$ e $0.0885 \mu \mathrm{M}$, respectivamente. Esse dado é indicativo que as células MYO5A KO têm uma maior sensibilidade à esta droga (Figura 36D), corroborando com nossos dados e indicando que a falta da miosina-Va leva à uma diminuição das propriedades malignas das células de melanoma, e um possível mecanismo para estes achados é o fato de há alterações na morfologia e função mitocondriais. 

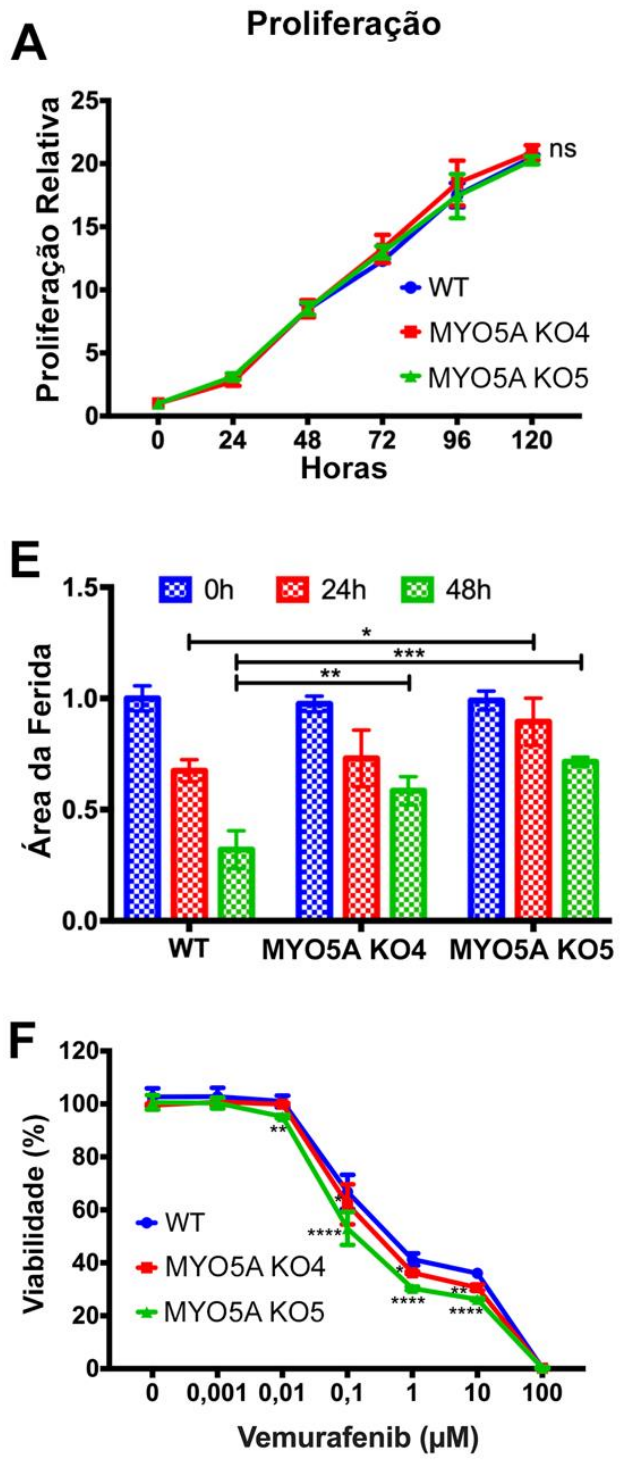

B
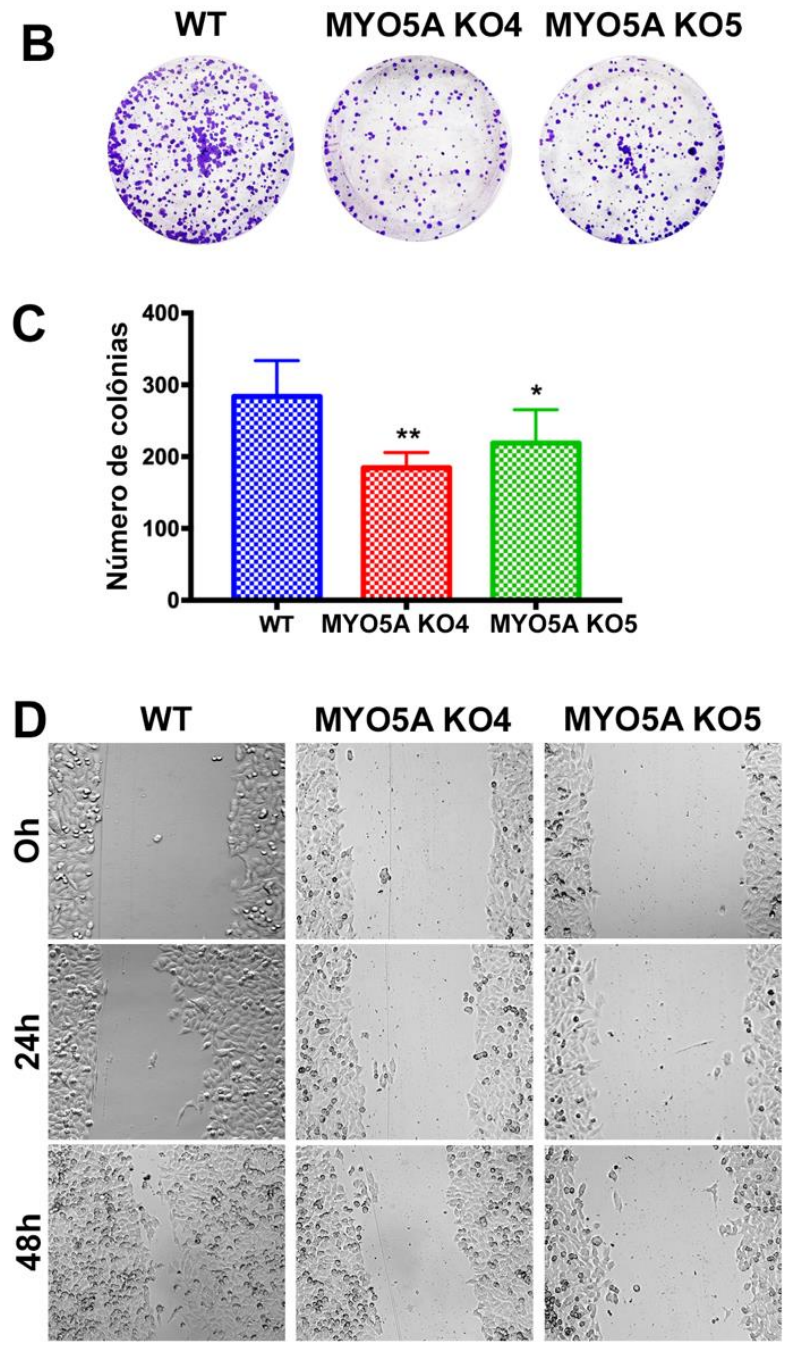

Figura 36. O nocaute da miosina-Va altera propriedades tumorigênicas das células de melanoma A375. A. Proliferação relativa das células A375 WT e MYO5A KO em diversos tempos. Os valores representam a absorbância (540nn) de cada tempo normalizada com o tempo zero. O gráfico representa a média \pm SD de 3 réplicas biológicas. 2-way ANOVA. B. Ensaio clonogênico das células A375 WT e MYO5A KO após 8 dias de cultivo em condições normais, imagens representativas de 3 experimentos independentes. C. Representação gráfica da contagem de colônias pertencentes ao experimento mostrado em $\mathbf{B}$. As colônias foram contadas no ImageJ. O gráfico representa a média \pm SD de 3 experimentos independentes. One-way ANOVA. D. Ensaio de Wound Healing nas células A375 WT e MYO5A KO avaliadas na hora da realização da ferida e após 24h e 48h para medir o grau de migração das células. E. Representação gráfica da área da ferida (inversamente proporcional à migração celular) referente ao experimento mostrado em $\mathbf{D}$. $\mathrm{O}$ gráfico representa a média $\pm \mathrm{SD}$ de 3 réplicas biológicas. 2-way ANOVA. F. Viabilidade das células A375 WT e MYO5A KO após tratamento com concentrações crescentes $(0,001 \mathrm{a} 100 \mu \mathrm{M})$ de Vemurafenib por $72 \mathrm{~h}$. A viabilidade foi medida através da redução de resazurin, que foi utilizado a uma concentração final de $700 \mu \mathrm{M}$. Os dados são a média \pm SD de 2 experimentos independentes. 2-way ANOVA. 


\section{Discussão}

Tem se tornado evidente que a compreensão dos mecanismos moleculares que regulam a dinâmica mitocondrial é fundamental para entendermos como morfologia e função mitocondrial se relacionam. A morfologia mitocondrial é mantida por ciclos de fusão e fissão, eventos cruciais para a célula, e que contribuem para o controle de qualidade das mitocôndrias e decisões do destino celular. Elucidar como esses eventos são regulados, do ponto de vista molecular e biológico, representa um passo crucial para a compreensão de inúmeras doenças humanas, como doenças neurodegenerativas, neuropatias genéticas e câncer. Nos últimos vinte anos, um grande progresso foi feito na identificação de componentes centrais e de fatores regulatórios das maquinarias envolvidas na dinâmica mitocondrial. Tivemos desde a identificação da participação do citoesqueleto de actina na fissão mitocondrial (Hatch et al., 2014) até a descoberta do controle da dinâmica mitocondrial de acordo com os ritmos circadianos (Schmitt et al., 2018). É notável que a descoberta de novos componentes celulares que regulam esses eventos está em constante evolução, e que continuará nos próximos anos com o desenvolvimento de novas tecnologias de microscopia e ferramentas genéticas.

Tendo este contexto em vista, e sabendo da importância do citoesqueleto nas funções mitocondriais, surgiu o interesse de analisar se a miosina-Va teria alguma relação com a rede mitocondrial. Sabemos que a miosina-Va é uma proteína ubiquamente expressa e dispersa por toda célula, mas a partir da nossa observação de que a miosina-Va possui uma localização mitocondrial, demonstrada tanto por experimentos de microscopia confocal e de superresolução (Figura 4), quanto por experimentos bioquímicos (Figura 5), nós postulamos que a miosina-Va teria um papel com relação à mitocôndria. Interessantemente, o grau de colocalização visto aqui é consistente com o observado anteriormente por nosso grupo em células de melanoma usando a técnica de coloração com partículas de ouro, em microscopia eletrônica (Nascimento et al., 1996).

Sendo assim, neste estudo nós focamos na compreensão do papel mecanicista da miosina-Va no processo de fissão mitocondrial, e uma das nossas principais descobertas foi a demonstração de que a miosina-Va interage com a proteína mitoSpire1 por meio de seu domínio da cauda e é recrutada por mitoSpire1 para a MME. É importante ressaltar que mitoSpire1 é uma isoforma com localização mitocondrial da proteína Spire1, e que as proteínas Spire1 são nucleadoras de actina. A mitoSpire1, especificamente, está envolvida na fissão mitocondrial e atua na nucleação de actina da mitocôndria em direção ao RE, o que favorece a formação de 
sítios de pré-constrição na membrana mitocondrial (Manor et al., 2015). Nossos dados mostram que a miosina-Va interage com mitoSpire1 e que a superexpressão de mitoSpire1 aumenta a localização da miosina-Va nas mitocôndrias, tanto quando analisamos a superexpressão da miosina-Va exógena, com tag GFP (Figura 7), como quando analisamos a miosina-Va endógena (Figura 9). Corroborando nossos dados, já foi demonstrado que as isoformas não mitocondriais de Spire1 interagem com os motores da miosina-V (Pylypenko et al., 2016). Ainda mais recentemente, foi mostrado que a interação entre miosina-Va e mitoSpire1 também está envolvida na ancoragem e posicionamento da mitocôndria nas células (Straub et al., 2020). A partir da confirmação desta interação e tendo em vista o papel da mitoSpire1 na fissão mitocondrial, nós direcionamos a nossa hipótese para a investigação de um possível papel para miosina-Va na fissão mitocondrial.

Já foi demonstrado que a miosina-Va é superexpressa em células de melanoma metastático, além de ser requerida para a sobrevivência independente de ancoragem, migração e invasão destas células (Alves et al., 2013). Sabendo desta importância da miosina-Va em melanoma, e sabendo também da importância da mitocôndria em várias características do câncer, como a regulação da morte celular programada, regulação do metabolismo, inflamação, instabilidade genômica e migração (Hanahan and Weinberg, 2011; Giampazolias and Tait, 2015), nós decidimos ir mais a fundo no papel mitocondrial da miosina-Va em células de melanoma. Para isso, nós escolhemos a linhagem celular de melanoma metastático humano A375 que abriga uma mutação BRAFV600E e, devido à essa mutação, possui mitocôndrias predominantemente fragmentadas, o que as torna um modelo útil para a compreensão da dinâmica mitocondrial no contexto do câncer (Abildgaard and Guldberg, 2015; Kashatus et al., 2015). Também vale a pena ressaltar que as células de melanoma exibem expressão do gene MYO5A relativamente alta (Alves et al., 2013) e, portanto, fornecem uma oportunidade única para estudar as funções da miosina-Va.

O alongamento mitocondrial desencadeado pelo silenciamento (Figura 11) e nocaute (Figura 14) de miosina-Va em células de melanoma A375 é consistente com o aumento relatado anteriormente no tamanho mitocondrial após o silenciamento da miosina-Va em neurônios (Pathak et al., 2010). Interessantemente, nós expandimos nossas análises e observamos que fibroblastos provindos de um paciente portador da Síndrome de Griscelli tipo I, ou seja, um fibroblasto nulo para MYO5A, também possui mitocôndrias alongadas quando o comparamos com um fibroblasto provindo de um doador saudável com idade e sexo pareados (Figura 15). Esta observação sugere que o papel mitocondrial da miosina-Va pode ser extrapolado para 
células não tumorais, e que possivelmente, a relação que entre miosina-Va e a morfologia mitocondrial não é restrita às células tumorais.

Corroborando o alongamento mitocondrial demonstrado por microscopia confocal, nós também observamos mudanças na ultraestrutura mitocondrial compatíveis com mitocôndrias com maior área e perímetro (Figuras 17 e 18), sob análise por microscopia eletrônica. Além disso, na análise da ultraestrutura mitocondrial, nós observamos que há uma menor superfície de contato entre a mitocôndria e o RE tanto nas células silenciadas quanto nas células KO para miosina-Va. Sabendo que os contatos entre mitocôndria e RE são de extrema importância para marcar os pontos de fissão, e para desencadear a fissão propriamente dita (Friedman et al., 2011; Chakrabarti et al., 2018), a diminuição da área de contato entre essa duas organelas pode ser o evento causal do alongamento mitocondrial visto aqui nas células depletadas para miosinaVa. Porém, não podemos deixar de ressaltar que apenas essa metodologia utilizada aqui, microscopia eletrônica, é falha para definir o contato entre essas duas organelas tão dinâmicas, e que novas análises são necessárias para gerarem conclusões definitivas sobre este tema.

A demonstração de que os transcritos das outras duas miosinas da classe $\mathrm{V}$, miosina- $\mathrm{Vb}$ e miosina-Vc, tem uma expressão muito baixa em células A375, em relação ao transcrito da miosina-Va já era esperado (Figura 19). Sabemos que a miosina-Va é predominantemente expressa em tecidos de origem neural, já a miosina-Vb é dispersa por outros tecidos, exceto tecidos neurais, e a miosina-Vc é predominante em tecidos epiteliais e glândulas exócrinas (Velvarska and Niessing, 2013). Sendo assim, também seria esperado que as miosina-Vb/Vc tivessem pouca ou nenhuma influência na morfologia mitocondrial das células A375. A partir da observação que o silenciamento da miosina- $\mathrm{Vb}$, ou da miosina- $\mathrm{Vc}$, ou de ambas miosina$\mathrm{Vb} / \mathrm{Vc}$ concomitante ao nocaute da miosina-Va também não altera significantemente a morfologia mitocondrial (Figura 20), nos leva a concluir que a miosina-Va não sofre redundância funcional em relação à sua função moduladora da morfologia mitocondrial. Entretanto, esse dado abre espaço para estudo da influência da miosina-Vb e miosina-Vc em células que possuem uma maior expressão dos genes $M Y O 5 B$ e $M Y O 5 C$ em detrimento do MYO5A.

Dados recentes da literatura mostram que os locais de replicação do mtDNA influenciam na fissão mitocondrial, sendo que os pontos de contato entre a mitocôndria e o RE marcariam os locais de replicação do mtDNA e subsequente fissão mitocondrial (Lewis et al., 2016). Tendo em vista o alongamento mitocondrial gerado pela depleção da miosina-Va nas células A375 e sabendo que mudanças na morfologia mitocondrial podem estar relacionadas a 
mudanças na estrutura dos nucleóides de mtDNA (Ashley and Poulton, 2009; Lewis et al., 2016), nós também analisamos a morfologia dos nucleióides de mtDNA nas células A375 MYO5A KO (Figura 21). Os nucleóides de mtDNA nada mais são do que estruturas compostas pelo mtDNA compactado por complexos de nucleoproteínas associadas. A proteína TFAM é o principal fator responsável pelo empacotamento do mtDNA em nucleóides, e também é essencial para o início da transcrição do mtDNA (Kukat and Larsson, 2013). Interessantemente, nós observamos que os nucleóides tem uma área e volume reduzidos nestas células, porém, sem mudanças no número total de nucleóides.

Também não observamos mudanças no número de cópias de mtDNA entre células A375 MYO5A KO e A375 WT (Figura 23). A ausência de alterações no número de nucleóides de mtDNA é concordante com a quantificação do número de cópias de mtDNA. Por sua vez, nossas observações são consistentes com os dados da literatura que mostram que, frequentemente, cada nucleóide contém uma cópia de mtDNA (Kukat and Larsson, 2013). Isso nos levanta hipóteses de que a replicação do mtDNA está mantida nas células A375 MYO5A $\mathrm{KO}$, mas que a organização e a estrutura do nucleóide está prejudicada.

Quando analisamos a expressão de proteínas relacionadas à dinâmica mitocondrial não encontramos diferenças significativas entre as células silenciadas para miosina-Va e células controle (Figuras 24 e 25). Isso demonstra que os efeitos gerados pela falta da miosina-Va na morfologia mitocondrial não ocorrem por alterações na expressão de proteínas chave da dinâmica mitocondrial. Mas quando analisamos a localização de tais proteínas em relação à rede mitocondrial vimos que há uma menor localização mitocondrial de Drp1, pDrp1(S616) e Mfn1 em células silenciadas. É difícil afirmar se essas diferenças implicam realmente em mudanças na rede mitocondrial, porém é sabido que uma deficiência no recrutamento de tais proteínas interfere nos processos da dinâmica mitocondrial (Westermann, 2010). Portanto, trabalhamos com a hipótese de que a miosina-Va poderia estar envolvida nesses processos direta ou indiretamente. Apenas Mfn2 apresentou uma localização aumentada na rede mitocondrial em células silenciadas para miosina-Va. Este dado pode ser interessante, porque Mfn2, ao contrário de Mfn1, está relacionada também a manutenção do contato entre as membranas da mitocôndria e do RE, o que é importante para diversas funções destas organelas (Schrepfer and Scorrano, 2016).

Dados os resultados de nossos experimentos com ionomicina, é interessante considerar que a atividade da miosina-Va é dependente do cálcio (Nascimento et al., 1996; Lu et al., 2006; Hammer and Wagner, 2013). Entre outros mecanismos, foi demonstrado que a miosina-Va se 
associa ao RE, se liga aos canais do receptor de cálcio da rianodina na membrana do RE, além de também responder ao cálcio derivado do RE associando-se a vesículas e direcionando-as para locais específicos (Wada et al., 2016). A possível diminuição do contato entre RE e mitocôndria, observada nas células depletadas para miosina-Va, também é consistente com um papel desencadeado por cálcio para a miosina-Va na interface entre RE e mitocôndria. Sabemos que a regulação do cálcio é de extrema importância para a fissão mitocondrial, sendo que é responsável por aumentar a polimerização da actina ao redor da mitocôndria, e actina age também recrutando Drp1 e induzindo assim a fissão mitocondrial (Wales et al., 2016; Chakrabarti et al., 2018).

Observamos que há um aumento da localização da miosina-Va na rede mitocondrial após estimulo com ionomicina (Figuras 26 e 28). Além disso, o aumento da localização mitocondrial de miosina-Va é acompanhado da presença da proteína Drp1 (Figura 28). O aumento da localização mitocondrial de Drp1 era esperado, e foi de extrema importância a constatação da presença da miosina-Va coexistindo com a maquinaria de fissão. Juntos, esses achados sugerem que a miosina-Va ajuda a regular a fissão mitocondrial, respondendo ao cálcio citoplasmático local, provavelmente sendo também atraída pelo aumento da polimerização de actina na membrana mitocondrial.

Posteriormente, nós analisamos o efeito que a falta da mitoSpire1 geraria na localização da miosina-Va nos sítios de fissão mitocondrial. Observamos que, de fato, células KO para mioSpire1 apresentam um recrutamento diminuído de miosina-Va para os locais de fissão mitocondrial (Figura 27), demostrando a importância da mitoSpire1 como um recrutador e regulador da atividade da miosina-Va na rede mitocondrial. Observando que a mitoSpire1 é importante para localização mitocondrial da miosina-Va, decidimos analisar se a mitoSpire1 também seria importante para localização da Drp1 nos pontos de fissão mitocondrial, levando em consideração que a polimerização de actina na membrana mitocondrial é um importante fator de recrutamento e maturação da Drp1 (Ji et al., 2015; Hatch et al., 2016). Porém, as células KO para mitoSpire1 não apresentaram diferenças no recrutamento de Drp1 (Figura 29), demonstrando que provavelmente o recrutamento da Drp1 não é afetado pela mitoSpire1, ou pela miosina-Va, já que a miosina-Va apresenta um menor recrutamento para mitocôndria na ausência da mitoSpire1.

Curiosamente, outros trabalhos já mostraram que as proteínas da família Spire interagem com as proteínas da família de miosina- $\mathrm{V}$, inclusive com a miosina-Va, para regular a motilidade das vesículas. Interessantemente, esses trabalhos sugerem que há também uma 
interação de ambas proteínas Spire1 e miosina-Va com a Rab11a (Pfender et al., 2011; Pylypenko et al., 2016). Tendo esse contexto em mente nós também analisamos a localização da Rab11a juntamente com a miosina-Va nas células KO para mitoSpire1. Observamos que a localização da Rab11a é extremamente similar à localização da cauda da miosina-Va (Figura 30), e que as duas proteínas estão frequentemente juntas nos pontos de fissão mitocondrial (Figura 31). Assim como ocorre com a miosina-Va, o KO da mitoSpire1 também diminui a localização de Rab11a nos pontos de fissão mitocondrial.

Dados da literatura já mostraram a presença da Rab11a nos pontos de fissão mitocondrial (Landry et al., 2014), mas os mecanismos moleculares da ação da Rab11a na fissão mitocondrial não foram elucidados. Nós demonstramos aqui que a falta da mitoSpire1 leva a um distanciamento de ambas Rab11 a e miosina-Va da rede mitocondrial. Isso indica que a presença da mitoSpire1 é necessária para o recrutamento da Rab11a e da miosina-Va para os pontos de fissão mitocondrial. A interação direta entre miosina-Va e mitoSpire1 demonstrada aqui, juntamente com a interação com Rab11a, é evidência para a formação de um complexo tripartite entre miosina-Va, mitoSpire1 e Rab11a que agem em prol da fissão mitocondrial. A formação deste complexo também ocorre com a isoforma não mitocondrial da Spire1, como é o caso em que há uma regulação conjunta de miosina-Va/Spire1/Rab11a na divisão assimétrica de oócitos em células de camundongos (Pfender et al., 2011), e as regiões moleculares de interação desse complexo já foram caracterizadas (Pylypenko et al., 2016). Nossos dados, em conjunto com evidências da literatura, sugerem um mecanismo molecular conservado pelo qual as proteínas miosina-Va, Rab GTPase, e as proteínas reguladoras da actina cooperam para regular a dinâmica das organelas ligadas à membrana.

Interessantemente, a Rab11a está principalmente localizada nas membranas do transGolgi, de vesículas pós-Golgi e em endossomos de reciclagem (Welz and Kerkhoff, 2019). Recentemente, foi mostrado que a fissão mitocondrial depende da entrega do fosfatidilinositol 4-fosfosfato (PI(4)P) em vesículas do trans-Golgi para os sítios de contato entre REmitocôndria e para os sítios de fissão mitocondrial, sendo que vesículas contendo PI(4)P também colocalizam com Drp1 nos sítios de fissão mitocondrial (Nagashima et al., 2020). Proteínas envolvidas na síntese de PI(4)P também estão envolvidas nesse processo, como a ARF1 que regula a produção de PI(4)P através da fosfadidilinositol 4-quinase III $\beta$ (PI4K $\beta$ ). Foi demonstrado que deleção dessas proteínas que regulam a produção de PI(4)P levam a um elongamento mitocondrial, mas não prejudicam o recrutamento de Drp1 (Ackema et al., 2014; Nagashima et al., 2020), similar ao que acontece nas nossas células nulas para mitoSpire1. Isso 
é consistente com um papel do complexo miosina-Va/mitoSpire1/Rab11a posterior ao recrutamento de Drp1, nos estágios finais da fissão mitocondrial.

Por fim, nós constatamos que o alongamento mitocondrial causado pela depleção da miosina-Va é realmente devido à uma menor ocorrência de eventos de fissão mitocondrial nestas células (Figura 32). O que nos leva a concluir que a miosina-Va tem uma importância na ocorrência dos eventos de fissão de mitocondrial. A partir deste contexto, nós analisamos a função metabólica mitocondrial das células A375 MYO5A KO e WT (Figuras 33 e 34). Na literatura é descrito que, frequentemente, um fenótipo de alongamento mitocondrial, resultante da diminuição dos eventos de fissão mitocondriais, gera um aumento das taxas de consumo de oxigênio, significando um aumento do metabolismo oxidativo mitocondrial (Mishra and Chan, 2016). Esses dados são baseados principalmente em experimentos realizados com células nulas ou silenciadas para Drp1 (Kashatus et al., 2015; Serasinghe et al., 2015). Porém, quando nós analisamos as taxas de consumo de oxigênio das células A375 MYO5A KO e também dos fibroblastos nulos para miosina-Va derivados de um paciente com síndrome de Griscelli-tipo 1 (Figura 33), nós observamos que as células depletadas para miosina-Va apresentam menores taxas de consumo de oxigênio, quando comparadas com células controle. Consistentemente, esses resultados corroboram com dados da literatura que mostram que ratos nulos para miosinaVa também apresentaram atividade enzimática do complexo respiratório I e IV prejudicada (Landrock et al., 2018), o que também é consistente com taxas de OCR mais baixas observadas nas células A375 MYO5A KO e nos fibroblastos humanos nulos para miosina-Va. Nossos resultados são indicativos que nem sempre mitocôndrias mais alongadas são condizentes com aumento da fosforilação oxidativa mitocondrial.

A redução no consumo de oxigênio nos fez aventar a hipótese de que provavelmente haveria danos nos componentes da cadeia respiratória, porém, quando analisamos esses componentes através de um western blot não foi possível observar diferenças na expressão de tais proteínas (Figura 34). Apesar deste resultado, novos experimentos serão necessários para determinar a atividade enzimática dos complexos da cadeia respiratória mitocondrial. Menores taxas de consumo de oxigênio poderiam significar uma diminuição no consumo glicolítico e produção de lactato pelas células (Kashatus, 2018), porém não observamos diferenças nesses metabólitos nas células A375 MYO5A KO (Figura 35), o que mais uma vez pode significar que as menores taxas de consumo de oxigênio observadas aqui não são devidas à disponibilidade de nutrientes, e sim, a alterações enzimáticas dos componentes da cadeia respiratória.

É importante também considerar que nós observamos um menor contato entre o RE e a 
mitocôndria (Figuras 17 e 18), o que pode implicar em uma homeostase de cálcio mitocondrial prejudicada. A atividade mitocondrial é dependente do cálcio captado através do RE, e essa transferência ocorre unicamente nas regiões de contato entre RE e mitocôndria (Phillips and Voeltz, 2016). A captação de cálcio pela mitocôndria é especialmente importante para estimulação do ciclo do ácido tricarboxílico, resultando em uma maior produção de energia, além de também agir na regulação da fissão da MMI, e na regulação de programas de morte celular (Chakrabarti et al., 2018; Nemani et al., 2018).

Um outro fator importante a ser considerado, é a transferência de lipídios que ocorre entre o RE e a mitocôndria. Enzimas que coordenam a síntese da maioria dos fosfolipídeos celulares estão localizadas em ambas membranas mitocondriais e reticulares (Horvath and Daum, 2013). Como é o caso da fosfatidilserina que é sintetizada no RE e pode ser alterada pela enzima fosfolipídio sintase, localizada na mitocôndria, para geração da fosfatidiletanolamina, que por sua vez é convertida a fofatidilcolina por enzimas localizadas no RE. Além disso, o ácido fosfatídico que é percursor da cardiolipina, um lipídeo de grande importância na composição das membranas mitocondriais, é sintetizado pelo RE e transferido para mitocôndria para modificações (Wu et al., 2018). Todas essas transferências lipídicas ocorrem por meio dos contatos entre as membranas da mitocôndria e do RE, que se mostrou diminuída nas células depletadas para miosina-Va. As membranas mitocondriais possuem composições únicas de fosfolípideos, que são responsáveis pelos seus formatos característicos. O desequilíbrio nas quantidades de qualquer um desses lipídeos causa prejuízos para integridade morfológica e funcional da mitocôndria. Já foi demonstrada que a deficiência de fosfatidiletanolamina, por exemplo, leva a uma diminuição da capacidade respiratória mitocondrial e menor produção energética (Horvath and Daum, 2013). Esses fatos abrem novas possibilidades para estudo do mecanismo pelo qual a falta da miosina-Va leva a uma diminuição da capacidade oxidativa das células e devem ser investigados no futuro.

Levando em consideração que as células de melanoma metastático humano A375 possuem a mutação BRAFV600E, que desencadeia a ativação constitutiva da via de MAPK, uma via envolvida na proliferação e sobrevivência celular nós também realizamos alguns ensaios funcionais para avaliar os efeitos que do $\mathrm{KO}$ da miosina-Va nas propriedades tumorigênicas das células A375 (Figura 36). A partir da nossa observação que as células A375 MYO5A KO possuem menores taxas de consumo de oxigênio, e sabendo que tanto as taxas proliferativas quantos migratórias podem responder às capacidades bioenergéticas das células (Kashatus, 2018), nós analisamos a taxa proliferativa e a capacidade de geração de colônia das 
células MYO5A KO. Apensar de não termos observado mudanças nas taxas proliferativas, nós observamos uma menor capacidade de formação de colônias. Esse dado sugere uma maior dificuldade de sobrevivência independente de contato célula-célula das células KO para miosina-Va. Além disso, também observamos menores taxas migratórias nas células MYO5A $\mathrm{KO}$, o que pode ser diretamente relacionado com uma menor produção de ATP, sendo que os processos migratórios são tão dispendiosos energeticamente paras as células. Por outro lado, evidências prévias do nosso grupo mostram também um papel para miosina-Va diretamente na desmontagem das adesões focais, por um mecanismo ainda não esclarecido (Ramão and Espreafico, 2014; Zenzen and Espreafico, 2019). Interessante notar que pode haver uma conexão entre o papel da miosina-Va na regulação do metabolismo mitocondrial e a desmontagem das adesões focais, uma vez que já foi descrito que a rede mitocondrial se acumula na frente migratória da célula, onde há uma intensa remodelação da rede actina e alta demanda energética (Zhao et al., 2013; Kashatus, 2018). Os processos de desmontagem das adesões necessitam de altos níveis de ATP, e a menor capacidade de produção energética das células nulas para miosina-Va mostrado aqui pode dificultar esses processos. Interessantemente, foi demonstrado também que há uma fragmentação mitocondrial das mitocôndrias presentes na frente migratória da célula (Zhao et al., 2013). A dificuldade, ou até inabilidade, que as células depletadas para miosina-Va tem de se fragmentar também pode ser outro fator interferente do processo migratório.

Analisamos também a viabilidade celular frente ao tratamento com a droga vemurafenib (PLX 4032), que é um inibidor seletivo para proteína BRAF mutada na posição V600E. Observamos que as células A375 MYO5A KO apresentaram viabilidade ligeiramente menor quando tratadas com Vemurafenib, em comparação com as células WT (Figura 36). Apesar de significativo, consideramos a diferença irrisória, e esse dado precisará ser investigado com maiores detalhes, alterando-se as condições de nutrientes e outros estímulos, como a privação de soro fetal no meio de cultura, e a privação da adesão celular a partir do cultivo em suspensão durante o tratamento. Entretanto, mais uma vez, esse dado nos levanta questões para investigação futura. Uma vez que o Vemurafenib é capaz de induzir um aumento da fosforilação oxidativa mitocondrial (Kashatus et al., 2015; Serasinghe et al., 2015) se confirmarmos uma alteração na sensibilidade das células MYO5A KO ao Vemurafenib poderá ser um indicativo de menor capacidade das células nulas para miosina-Va de acionar o funcionamento mitocondrial pleno em situação de maior demanda energética, indicando a menor eficiência do metabolismo mitocondrial. 
Os dados obtidos neste trabalho de tese marcam o início de estudos aprofundados sobre o mecanismo preciso pelo qual a miosina-Va afeta a morfologia e função mitocondrial. Nós postulamos que mitoSpire1, Rab11a e miosina-Va atuem juntas, formando um complexo tripartite com a função de promover a fissão mitocondrial. Ainda é incerto se Rab11a é diretamente recrutada para MME ou se ela vai até a mitocôndria através de vesículas para reciclagem ou entrega de outros componentes essenciais para fissão mitocondrial (Figura 37). Portanto, a falta de uma ou mais dos componentes do complexo miosina$\mathrm{Va} /$ mitoSpire1/Rab11a gera um alongamento mitocondrial que culmina em prejuízo da função metabólica mitocondrial. Interessantemente, esses eventos parecem ser globais, independentes do tipo celular. Porém, no contexto de células tumorais, esses efeitos parecem ser promissores no sentido de diminuir as propriedades tumorais.

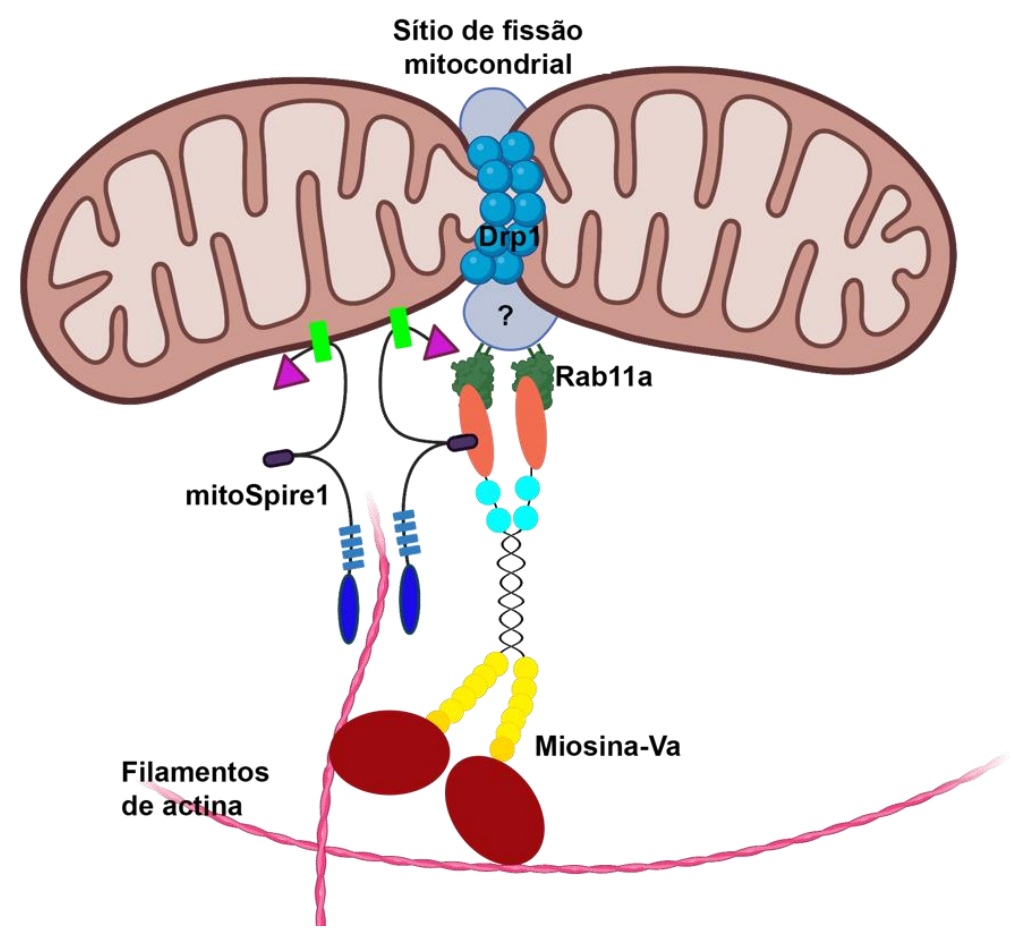

Figura 37. Modelo esquemático da atuação do complexo miosina-Va/mitoSpire1/Rab11a na fissão mitocondrial. mitoSpire1 é ligada à MME através do seu exón C (13ºxón). mitoSpire1 polimeriza actina em direção ao RE (não mostrado) que contribui para pré-contrição mitocondrial. A miosina-Va é recrutada, através da mitoSpire1 por meio de um domínio conservado de interação com a miosina-Va, chamado de GTBM (motivo globular de ligação ao domínio cauda da miosina-V), juntamente com a Rab11a para a MME no momento da fissão mitocondrial. Ainda é incerto se a Rab11a é recrutada diretamente ou se através da sua ligação com alguma vesícula. Também ainda é incerto o exato mecanismo de ação da miosina-Va e da Rab11a nos locais de fissão mitocondrial. (mitoSpire1: FYVE, magenta; éxonC, verde claro; GTBM, roxo escuro; WH2, azul claro; KIND, azul escuro. Miosina-Va: cauda globular, alaranjado; coiled-coils, púrpura, cauda medial, azul claro; pescoço motivos IQ, amarelo claro; pescoço - sítio de ligação de cadeias leves, amarelo escuro; domínio motor, vermelho; Rab11a, verde; Drp1, azul; filamentos de actina em vermelho). 


\section{Conclusão}

A partir de extensivas análises de microscopia nós identificamos a localização da miosina-Va na rede mitocondrial, e mais especificamente, nos pontos de fissão mitocondrial. Um dos nossos principais achados foi o fato de que a miosina-Va é recrutada para membrana mitocondrial externa pela proteína mitoSpire1, e que a mitoSpire1 é necessária para presença tanto da miosina-Va, quanto da proteína Rab11a, nos pontos de fissão mitocondrial. A partir destas observações, postulamos aqui que mitoSpire1, Rab11a e miosina-Va provavelmente interagem em forma de complexo para promover a fissão mitocondrial. Através da manipulação da expressão do gene MYO5A, utilizando shRNAs e CRISPR, nós identificamos que a depleção da miosina-Va leva a um fenótipo de alongamento mitocondrial, consistente com um menor número de eventos de fissão mitocondrial observados nestas células. No contexto tumoral, vemos que o alongamento mitocondrial acarreta em uma menor função metabólica mitocondrial, demonstrado pelas menores taxas de consumo de oxigênio e produção de ATP apresentada pelas células A375 MYO5A KO. Ainda no contexto tumoral, a depleção da miosina-Va levou a uma atenuação de propriedades relacionadas à malignidade das células A375. Porém, acreditamos que os efeitos morfológicos e metabólicos mitocondriais causados pela depleção da miosina-Va sejam globais e independentes do tipo celular, já que também observamos tais mudanças em fibroblastos nulos para miosina-Va, provindos de pacientes com Síndrome de Griscelli-tipo 1. Por fim, nós concluímos que a miosina-Va é uma proteína importante para manutenção da morfologia e metabolismo mitocondrial, a partir da sua participação no processo de fissão mitocondrial. 


\section{Referências}

ABILDGAARD, C.; GULDBERG, P. Molecular drivers of cellular metabolic reprogramming in melanoma. Trends Mol Med, v. 21, n. 3, p. 164-71, Mar 2015. ISSN 1471-4914. Available at: < http://dx.doi.org/10.1016/j.molmed.2014.12.007 >.

ACKEMA, $K$. et al. The small GTPase Arf1 modulates mitochondrial morphology and function. The EMBO journal, v. 33, n. 22, 11/18/2014 2014. ISSN 1460-2075. Available at: < https://www.ncbi.nlm.nih.gov/pubmed/25190516 >.

AJ, V. et al. A simple ImageJ macro tool for analyzing mitochondrial network morphology in mammalian cell culture. Acta histochemica, v. 119, n. 3, 2017 Apr 2017. ISSN 1618-0372. Available at: $<$ https://www.ncbi.nlm.nih.gov/pubmed/28314612 >.

ALVES, C. P. et al. Myosin-Va contributes to manifestation of malignant-related properties in melanoma cells. J Invest Dermatol, v. 133, n. 12, p. 2809-12, Dec 2013. ISSN 1523-1747. Available at: $<$ http://www.ncbi.nlm.nih.gov/pubmed/23652798 >.

. MYO5A Gene Is a Target of MITF in Melanocytes. J Invest Dermatol, v. 137, n. 4, p. 985-989, Apr 2017. ISSN 0022-202x. Available at: < http://dx.doi.org/10.1016/j.jid.2016.11.026 >.

ANAND, $R$. et al. The $\mathrm{i}-\mathrm{AAA}$ protease YME1L and OMA1 cleave OPA1 to balance mitochondrial fusion and fission. J Cell Biol, v. 204, n. 6, p. 919-29, Mar 17 2014. ISSN 0021-9525. Available at: < http://dx.doi.org/10.1083/jcb.201308006 >.

ARAUJO, J. S. et al. A novel role for Myosin-Va in mitochondrial fission. 2019-05-31 2019. Available at: $<$ https://www.biorxiv.org/content/10.1101/655803v1.article-metrics $>$.

ASHLEY, N.; POULTON, J. Anticancer DNA intercalators cause p53-dependent mitochondrial DNA nucleoid re-modelling. Oncogene, v. 28, n. 44, 11/05/2009 2009. ISSN 1476-5594. Available at: < https://www.ncbi.nlm.nih.gov/pubmed/19684617 >.

ASSIS, L. H. et al. The molecular motor Myosin Va interacts with the cilia-centrosomal protein RPGRIP1L. Sci Rep, v. 7, p. 43692, Mar 7 2017. ISSN 2045-2322. Available at: < http://dx.doi.org/10.1038/srep43692 >.

BAN, T. et al. Molecular basis of selective mitochondrial fusion by heterotypic action between OPA1 and cardiolipin. Nature cell biology, v. 19, n. 7, 2017 Jul 2017. ISSN 1476-4679. Available at: < https://www.ncbi.nlm.nih.gov/pubmed/28628083 >.

BOLDOGH, I. R. et al. A type V myosin (Myo2p) and a Rab-like G-protein (Ypt11p) are required for retention of newly inherited mitochondria in yeast cells during cell division. Mol Biol Cell, v. 15, n. 9, p. 3994-4002, Sep 2004. ISSN 1059-1524 (Print)

1059-1524 (Linking). Available at: < http://www.ncbi.nlm.nih.gov/pubmed/15215313 >.

BORDI, M.; NAZIO, F.; CAMPELLO, S. The Close Interconnection between Mitochondrial Dynamics and Mitophagy in Cancer. Front Oncol, v. 7, p. 81, 2017. ISSN 2234-943X (Print)2234-943x. Available at: < http://dx.doi.org/10.3389/fonc.2017.00081 >. 
CAO, Y. et al. MFN1 structures reveal nucleotide-triggered dimerization critical for mitochondrial fusion. Nature, v. 542, n. 7641, 02/16/2017 2017. ISSN 1476-4687. Available at: < https://www.ncbi.nlm.nih.gov/pubmed/28114303 >.

CHAKRABARTI, R. et al. INF2-mediated actin polymerization at the ER stimulates mitochondrial calcium uptake, inner membrane constriction, and division. J Cell Biol, v. 217, n. 1, p. 251-268, Jan 2 2018. ISSN 1540-8140 (Electronic)

0021-9525 (Linking). Available at: < https://www.ncbi.nlm.nih.gov/pubmed/29142021 >.

CHANDEL, N. S. Evolution of Mitochondria as Signaling Organelles. Cell Metab, v. 22, n. 2, p. 204-6, Aug 2015. ISSN 1932-7420. Available at: < https://www.ncbi.nlm.nih.gov/pubmed/26073494 >.

CHEN, H.; CHAN, D. C. Mitochondrial Dynamics in Regulating the Unique Phenotypes of Cancer and Stem Cells. Cell Metab, v. 26, n. 1, p. 39-48, Jul 5 2017. ISSN 1550-4131. Available at: < http://dx.doi.org/10.1016/j.cmet.2017.05.016 >.

CHEN, Y. et al. Rab10 and myosin-Va mediate insulin-stimulated GLUT4 storage vesicle translocation in adipocytes. J Cell Biol, v. 198, n. 4, p. 545-60, Aug 20 2012. ISSN 1540-8140 (Electronic) 0021-9525 (Linking). Available at: < http://www.ncbi.nlm.nih.gov/pubmed/22908308 >.

CHENEY, R. E. et al. Brain myosin-V is a two-headed unconventional myosin with motor activity. Cell, v. 75, n. 1 , p. 13-23, Oct 1993. ISSN 0092-8674. Available at: < http://www.ncbi.nlm.nih.gov/pubmed/8402892 >.

CHENEY, R. E.; RILEY, M. A.; MOOSEKER, M. S. Phylogenetic analysis of the myosin superfamily. Cell Motil Cytoskeleton, v. 24, n. 4, p. 215-23, 1993. ISSN 0886-1544. Available at: < http://www.ncbi.nlm.nih.gov/pubmed/8477454 >.

CHENEY, R. E.; RODRIGUEZ, O. C. Cell biology. A switch to release the motor. Science, v. 293, n. 5533, p. 1263-4, Aug 2001. ISSN 0036-8075. Available at: < http://www.ncbi.nlm.nih.gov/pubmed/11509712 >.

CIPOLAT, S. et al. OPA1 requires mitofusin 1 to promote mitochondrial fusion. Proc Natl Acad Sci U S A, v. 101 , n. 45 , p. 15927-32, Nov 9 2004. ISSN 0027-8424 (Print)0027-8424. Available at: < http://dx.doi.org/10.1073/pnas.0407043101 >.

COGLIATI, S.; ENRIQUEZ, J.; SCORRANO, L. Mitochondrial Cristae: Where Beauty Meets Functionality. Trends in biochemical sciences, v. 41, n. 3, 2016 Mar 2016. ISSN 0968-0004. Available at: < https://www.ncbi.nlm.nih.gov/pubmed/26857402 >.

COGLIATI, S. et al. Mitochondrial cristae shape determines respiratory chain supercomplexes assembly and respiratory efficiency. Cell, v. 155, n. 1, 09/26/2013 2013. ISSN 1097-4172. Available at: < https://www.ncbi.nlm.nih.gov/pubmed/24055366 >.

DA SILVA BIZARIO, J. C. et al. Expression of constructs of the neuronal isoform of myosin-Va interferes with the distribution of melanosomes and other vesicles in melanoma cells. Cell Motil Cytoskeleton, v. 51, n. 2, p. 57-75, Feb 2002. ISSN 0886-1544. Available at: < http://www.ncbi.nlm.nih.gov/pubmed/11921164 >. 
DASTE, F. et al. The heptad repeat domain 1 of Mitofusin has membrane destabilization function in mitochondrial fusion. EMBO reports, v. 19, n. 6, 2018 Jun 2018. ISSN 1469-3178. Available at: < https://www.ncbi.nlm.nih.gov/pubmed/29661855 >.

DAUMKE, O.; PRAEFCKE, G. Mechanisms of GTP hydrolysis and conformational transitions in the dynamin superfamily. Biopolymers, v. 109, n. 2, 2018 Feb 2018. ISSN 1097-0282. Available at: < https://www.ncbi.nlm.nih.gov/pubmed/29476548 >.

DEVAY, R. et al. Coassembly of Mgm1 isoforms requires cardiolipin and mediates mitochondrial inner membrane fusion. The Journal of cell biology, v. 186, n. 6, 09/21/2009 2009. ISSN 1540-8140. Available at: < https://www.ncbi.nlm.nih.gov/pubmed/19752025 >.

DU, Y. C. et al. Assessing tumor progression factors by somatic gene transfer into a mouse model: BclxL promotes islet tumor cell invasion. PLoS Biol, v. 5, n. 10, p. e276, Oct 2007. ISSN 1545-7885. Available at: $<$ http://www.ncbi.nlm.nih.gov/pubmed/17941720 $>$.

ELACHOURI, G. et al. OPA1 links human mitochondrial genome maintenance to mtDNA replication and distribution. Genome research, v. 21, n. 1, 2011 Jan 2011. ISSN 1549-5469. Available at: < https://www.ncbi.nlm.nih.gov/pubmed/20974897 >.

ESPINDOLA, F. S. et al. Biochemical and immunological characterization of p190-calmodulin complex from vertebrate brain: a novel calmodulin-binding myosin. J Cell Biol, v. 118, n. 2, p. 359-68, Jul 1992. ISSN 0021-9525 (Print)0021-9525. Available at: < http://dx.doi.org/10.1083/jcb.118.2.359 >.

ESPREAFICO, E. M. et al. Primary structure and cellular localization of chicken brain myosin-V (p190), an unconventional myosin with calmodulin light chains. J Cell Biol, v. 119, n. 6, p. 1541-57, Dec 1992. ISSN 0021-9525. Available at: < http://www.ncbi.nlm.nih.gov/pubmed/1469047 >.

. Localization of myosin-V in the centrosome. Proc Natl Acad Sci U S A, v. 95, n. 15, p. 8636-41, Jul 1998. ISSN 0027-8424. Available at: < http://www.ncbi.nlm.nih.gov/pubmed/9671730 >.

FINAN, D.; HARTMAN, M. A.; SPUDICH, J. A. Proteomics approach to study the functions of Drosophila myosin VI through identification of multiple cargo-binding proteins. Proc Natl Acad Sci U S A, v. 108, n. 14 , p. 5566-71, Apr 5 2011. ISSN 0027-8424. Available at: < http://dx.doi.org/10.1073/pnas.1101415108 >.

FLETCHER, D.; MULLINS, R. Cell mechanics and the cytoskeleton. Nature, v. 463, n. 7280, 01/28/2010 2010. ISSN 1476-4687. Available at: < https://www.ncbi.nlm.nih.gov/pubmed/20110992 >.

FREZZA, C. et al. OPA1 controls apoptotic cristae remodeling independently from mitochondrial fusion. Cell, v. 126, n. 1, 07/14/2006 2006. ISSN 0092-8674. Available at: < https://www.ncbi.nlm.nih.gov/pubmed/16839885 >.

FRIEDMAN, J. R. et al. ER tubules mark sites of mitochondrial division. Science, v. 334, n. 6054, p. 35862, Oct 21 2011. ISSN 0036-8075. Available at: < http://dx.doi.org/10.1126/science.1207385 >.

FUKUDA, M.; KURODA, T.; MIKOSHIBA, K. Slac2-a/melanophilin, the missing link between Rab27 and myosin Va: implications of a tripartite protein complex for melanosome transport. The Journal of biological chemistry, v. 277, n. 14, 04/05/2002 2002. ISSN 0021-9258. Available at: < https://www.ncbi.nlm.nih.gov/pubmed/11856727 >. 
FÖRTSCH, J. et al. The myosin-related motor protein Myo2 is an essential mediator of bud-directed mitochondrial movement in yeast. J Cell Biol, v. 194, n. 3, p. 473-88, Aug 2011. ISSN 1540-8140. Available at: < http://www.ncbi.nlm.nih.gov/pubmed/21807878 $>$.

FÜLÖP, L. et al. Mitochondrial Ca2+ uptake correlates with the severity of the symptoms in autosomal dominant optic atrophy. Cell calcium, v. 57, n. 1, 2015 Jan 2015. ISSN 1532-1991. Available at: < https://www.ncbi.nlm.nih.gov/pubmed/25533789 >.

GAO, S.; HU, J. Mitochondrial Fusion: The Machineries In and Out. Trends in cell biology, 10/19/2020 2020. ISSN 1879-3088. Available at: < https://www.ncbi.nlm.nih.gov/pubmed/33092941 >.

GIAMPAZOLIAS, E.; TAIT, S. W. Mitochondria and the hallmarks of cancer. FEBS J, Nov 2015. ISSN $1742-$ 4658. Available at: < http://www.ncbi.nlm.nih.gov/pubmed/26607558 >.

GOODSON, H.; JONASSON, E. Microtubules and Microtubule-Associated Proteins. Cold Spring Harbor perspectives in biology, v. 10, n. 6, 06/01/2018 2018. ISSN 1943-0264. Available at: < https://www.ncbi.nlm.nih.gov/pubmed/29858272 >.

GRIPARIC, L.; KANAZAWA, T.; VAN DER BLIEK, A. Regulation of the mitochondrial dynamin-like protein Opa1 by proteolytic cleavage. The Journal of cell biology, v. 178, n. 5, 08/27/2007 2007. ISSN 0021 9525. Available at: < https://www.ncbi.nlm.nih.gov/pubmed/17709430 $>$.

HAMMER, J. A., 3RD; WAGNER, W. Functions of class V myosins in neurons. J Biol Chem, v. 288, n. 40, p. 28428-34, Oct 4 2013. ISSN 0021-9258. Available at: < http://dx.doi.org/10.1074/jbc.R113.514497 >.

HANAHAN, D.; WEINBERG, R. A. Hallmarks of cancer: the next generation. Cell, v. 144, n. 5, p. 646-74, Mar 2011. ISSN 1097-4172. Available at: < http://www.ncbi.nlm.nih.gov/pubmed/21376230 >.

$H A Q$, R. et al. Oncogenic BRAF regulates oxidative metabolism via PGC1alpha and MITF. Cancer Cell, v. 23, n. 3 , p. 302-15, Mar 18 2013. ISSN 1535-6108. Available at: < http://dx.doi.org/10.1016/j.ccr.2013.02.003 >.

HATCH, A. L.; GUREL, P. S.; HIGGS, H. N. Novel roles for actin in mitochondrial fission. J Cell Sci, v. 127, n. Pt 21, p. 4549-60, Nov 1 2014. ISSN 0021-9533. Available at: < http://dx.doi.org/10.1242/jcs.153791 >.

HATCH, A. L. et al. Actin filaments as dynamic reservoirs for Drp1 recruitment. Mol Biol Cell, v. 27, n. 20, p. 3109-3121, Oct 15 2016. ISSN 1939-4586 (Electronic)

1059-1524 (Linking). Available at: < https://www.ncbi.nlm.nih.gov/pubmed/27559132 >.

HE, L. et al. Extracting Accurate Precursor Information for Tandem Mass Spectra by RawConverter. Anal Chem, v. 87, n. 22, p. 11361-7, Nov 17 2015. ISSN 0003-2700. Available at: < http://dx.doi.org/10.1021/acs.analchem.5b02721 >.

HODIS, E. et al. A Landscape of Driver Mutations in Melanoma. Cell, v. 150, n. 2, p. 251-63, Jul 202012. ISSN 0092-8674 (Print)1097-4172 $\quad$ (Electronic). Available at: < http://dx.doi.org/10.1016/j.cell.2012.06.024 >. 
HOHMANN, T.; DEHGHANI, F. The Cytoskeleton-A Complex Interacting Meshwork. Cells, v. 8, n. 4, 04/18/2019 2019. ISSN 2073-4409. Available at: < https://www.ncbi.nlm.nih.gov/pubmed/31003495 >.

HORVATH, S.; DAUM, G. Lipids of mitochondria. Progress in lipid research, v. 52, n. 4, 2013 Oct 2013. ISSN 1873-2194. Available at: < https://www.ncbi.nlm.nih.gov/pubmed/24007978 >.

HUME, A. et al. The leaden gene product is required with Rab27a to recruit myosin $\mathrm{Va}$ to melanosomes in melanocytes. Traffic (Copenhagen, Denmark), v. 3, n. 3, 2002 Mar 2002. ISSN 1398-9219. Available at: < https://www.ncbi.nlm.nih.gov/pubmed/11886590 $>$.

IZIDORO-TOLEDO, T. C. et al. A myosin-Va tail fragment sequesters dynein light chains leading to apoptosis in melanoma cells. Cell Death Dis, v. 4, p. e547, 2013. ISSN 2041-4889. Available at: < http://www.ncbi.nlm.nih.gov/pubmed/23519116 >.

$\mathrm{JI}, \mathrm{W}$. et al. Actin filaments target the oligomeric maturation of the dynamin GTPase Drp1 to mitochondrial fission sites. In: (Ed.). eLife, v.4, 2015. ISBN 2050-084X (Electronic).

KASHATUS, D. The regulation of tumor cell physiology by mitochondrial dynamics. Biochemical and biophysical research communications, v. 500, n. 1, 05/27/2018 2018. ISSN 1090-2104. Available at: < https://www.ncbi.nlm.nih.gov/pubmed/28676396 >.

KASHATUS, J. A. et al. Erk2 phosphorylation of Drp1 promotes mitochondrial fission and MAPK-driven tumor growth. Mol Cell, v. 57, n. 3, p. 537-51, Feb 05 2015. ISSN 1097-2765. Available at: < http://dx.doi.org/10.1016/j.molcel.2015.01.002 >.

KELLER, H. R. et al. Overcoming resistance to targeted therapy with immunotherapy and combination therapy for metastatic melanoma. Oncotarget, v. 8, n. 43, p. 75675-75686, Sep 26 2017. ISSN 19492553. Available at: < http://dx.doi.org/10.18632/oncotarget.18523 >.

KELLY, E. et al. The Rab family of proteins: 25 years on. Biochemical Society transactions, v. 40, n. 6 , 12/01/2012 2012. ISSN 1470-8752. Available at: < https://www.ncbi.nlm.nih.gov/pubmed/23176478 >.

KOROBOVA, F.; GAUVIN, T. J.; HIGGS, H. N. A role for myosin II in mammalian mitochondrial fission. Curr Biol, v. 24, n. 4, p. 409-14, Feb 17 2014. ISSN 0960-9822. Available at: < http://dx.doi.org/10.1016/j.cub.2013.12.032 >.

KOROBOVA, F.; RAMABHADRAN, V.; HIGGS, H. N. An actin-dependent step in mitochondrial fission mediated by the ER-associated formin INF2. Science, v. 339, n. 6118, p. 464-7, Jan 25 2013. ISSN 00368075. Available at: < http://dx.doi.org/10.1126/science.1228360 >.

KOSHIBA, T. et al. Structural basis of mitochondrial tethering by mitofusin complexes. Science (New York, N.Y.), v. 305, n. 5685, 08/06/2004 2004. ISSN 1095-9203. Available at: < https://www.ncbi.nlm.nih.gov/pubmed/15297672 >.

KRAUS, F.; RYAN, M. T. The constriction and scission machineries involved in mitochondrial fission. J Cell Sci, v. 130, n. 18, p. 2953-2960, Sep 15 2017. ISSN 0021-9533. Available at: < http://dx.doi.org/10.1242/jcs.199562 >. 
KREMENTSOV, D.; KREMENTSOVA, E.; TRYBUS, K. Myosin V: regulation by calcium, calmodulin, and the tail domain. The Journal of cell biology, v. 164, n. 6, 03/15/2004 2004. ISSN 0021-9525. Available at: < https://www.ncbi.nlm.nih.gov/pubmed/15007063 >.

KUKAT, C.; LARSSON, N. mtDNA makes a U-turn for the mitochondrial nucleoid. Trends in cell biology, v. 23, n. 9, 2013 Sep 2013. ISSN 1879-3088. Available at: < https://www.ncbi.nlm.nih.gov/pubmed/23721879 >.

LABBÉ, K.; MURLEY, A.; NUNNARI, J. Determinants and functions of mitochondrial behavior. Annual review of cell and developmental biology, v. 30, 2014 2014. ISSN 1530-8995. Available at: < https://www.ncbi.nlm.nih.gov/pubmed/25288115 >.

LAGACHE, T. et al. Statistical analysis of molecule colocalization in bioimaging. Cytometry. Part A : the journal of the International Society for Analytical Cytology, v. 87, n. 6, 2015 Jun 2015. ISSN 15524930. Available at: < https://www.ncbi.nlm.nih.gov/pubmed/25605428 $>$.

LAN, L. et al. Upregulation of myosin Va by Snail is involved in cancer cell migration and metastasis. Int J Cancer, v. 126, n. 1, p. 53-64, Jan 2010. ISSN 1097-0215. Available at: < http://www.ncbi.nlm.nih.gov/pubmed/19521958 >.

LANDROCK, K. et al. Pleiotropic neuropathological and biochemical alterations associated with Myo5a mutation in a rat Model. Brain research, v. 1679, 01/15/2018 2018. ISSN 1872-6240. Available at: < https://www.ncbi.nlm.nih.gov/pubmed/29217155 >.

LANDRY, M. C. et al. A functional interplay between the small GTPase Rab11a and mitochondriashaping proteins regulates mitochondrial positioning and polarization of the actin cytoskeleton downstream of Src family kinases. J Biol Chem, v. 289, n. 4, p. 2230-49, Jan 24 2014. ISSN 0021-9258. Available at: < http://dx.doi.org/10.1074/jbc.M113.516351 >.

LEE, J. et al. Multiple dynamin family members collaborate to drive mitochondrial division. Nature, $\mathrm{v}$. 540, n. 7631, 12/01/2016 2016. ISSN 1476-4687. Available at: < https://www.ncbi.nlm.nih.gov/pubmed/27798601 >.

LEWIS, S. C.; UCHIYAMA, L. F.; NUNNARI, J. ER-mitochondria contacts couple mtDNA synthesis with mitochondrial division in human cells. Science, v. 353, n. 6296, p. aaf5549, Jul 2016. ISSN 1095-9203. Available at: $<$ https://www.ncbi.nlm.nih.gov/pubmed/27418514 $>$.

$\mathrm{LI}, \mathrm{S}$. et al. Transient assembly of F-actin on the outer mitochondrial membrane contributes to mitochondrial fission. J Cell Biol, v. 208, n. 1, p. 109-23, Jan 2015. ISSN 1540-8140. Available at: < http://www.ncbi.nlm.nih.gov/pubmed/25547155 >.

LI, X.; IKEBE, R.; IKEBE, M. Activation of myosin Va function by melanophilin, a specific docking partner of myosin Va. The Journal of biological chemistry, v. 280, n. 18, 05/06/2005 2005. ISSN 0021-9258. Available at: < https://www.ncbi.nlm.nih.gov/pubmed/15760894 >.

LI, Y. et al. Structural insights of human mitofusin-2 into mitochondrial fusion and CMT2A onset. Nature communications, v. 10 , n. 1, 10/29/2019 2019. ISSN 2041-1723. Available at: < https://www.ncbi.nlm.nih.gov/pubmed/31664033 >. 
LINDSAY, A. et al. Identification and characterization of multiple novel Rab-myosin Va interactions. Molecular biology of the cell, v. 24, n. 21, 2013 Nov 2013. ISSN 1939-4586. Available at: < https://www.ncbi.nlm.nih.gov/pubmed/24006491 >.

LIU, J. et al. Three-dimensional structure of the myosin V inhibited state by cryoelectron tomography. Nature, v. 442, n. 7099, 07/13/2006 2006. ISSN 1476-4687. Available at: < https://www.ncbi.nlm.nih.gov/pubmed/16625208 >.

LOSON, O. C. et al. Fis1, Mff, MiD49, and MiD51 mediate Drp1 recruitment in mitochondrial fission. Mol Biol Cell, v. 24, n. 5, p. 659-67, Mar 2013. ISSN 1059-1524. Available at: < http://dx.doi.org/10.1091/mbc.E12-10-0721 >.

LU, H.; KREMENTSOVA, E. B.; TRYBUS, K. M. Regulation of myosin $V$ processivity by calcium at the single molecule level. J Biol Chem, v. 281, n. 42, p. 31987-94, Oct 20 2006. ISSN 0021-9258 (Print)0021-9258. Available at: < http://dx.doi.org/10.1074/jbc.M605181200 >.

MACVICAR, T.; LANGER, T. OPA1 processing in cell death and disease - the long and short of it. J Cell Sci, v. 129, n. 12, p. 2297-306, Jun 15 2016. ISSN 0021-9533. Available at: < http://dx.doi.org/10.1242/jcs.159186 >.

MANOR, U. et al. A mitochondria-anchored isoform of the actin-nucleating spire protein regulates mitochondrial division. Elife, v. 4, Aug 25 2015. ISSN 2050-084X (Electronic)

2050-084X (Linking). Available at: < https://www.ncbi.nlm.nih.gov/pubmed/26305500 >

MASTERS, T. A.; KENDRICK-JONES, J.; BUSS, F. Myosins: Domain Organisation, Motor Properties, Physiological Roles and Cellular Functions. Handb Exp Pharmacol, v. 235, p. 77-122, 2017. ISSN 01712004 (Print)0171-2004. Available at: < http://dx.doi.org/10.1007/164 201629 >.

MISHRA, P.; CHAN, D. C. Mitochondrial dynamics and inheritance during cell division, development and disease. Nat Rev Mol Cell Biol, v. 15, n. 10, p. 634-46, Oct 2014. ISSN 1471-0080. Available at: < https://www.ncbi.nlm.nih.gov/pubmed/25237825 >.

. Metabolic regulation of mitochondrial dynamics. J Cell Biol, v. 212, n. 4, p. 379-87, Feb 2016. ISSN 1540-8140. Available at: < https://www.ncbi.nlm.nih.gov/pubmed/26858267 >.

MÉNASCHÉ, G.; FISCHER, A.; DE SAINT BASILE, G. Griscelli syndrome types 1 and 2. American journal of human genetics, v. 71, n. 5, 2002 Nov 2002. ISSN 0002-9297. Available at: < https://www.ncbi.nlm.nih.gov/pubmed/12452176 >.

NAGASHIMA, S. et al. Golgi-derived PI ( 4 ) P-containing vesicles drive late steps of mitochondrial division. Science (New York, N.Y.), v. 367, n. 6484, 03/20/2020 2020. ISSN 1095-9203. Available at: < https://www.ncbi.nlm.nih.gov/pubmed/32193326 >.

NASCIMENTO, A.; ROLAND, J.; GELFAND, V. Pigment cells: a model for the study of organelle transport. Annual review of cell and developmental biology, v. 19, 2003 2003. ISSN 1081-0706. Available at: < https://www.ncbi.nlm.nih.gov/pubmed/14570578 >.

NASCIMENTO, A. A. et al. Subcellular localization of myosin-V in the B16 melanoma cells, a wild-type cell line for the dilute gene. Mol Biol Cell, v. 8, n. 10, p. 1971-88, Oct 1997. ISSN 1059-1524. Available at: < http://www.ncbi.nlm.nih.gov/pubmed/9348537 >. 
. Enzymatic characterization and functional domain mapping of brain myosin-V. J Biol Chem, v. 271, n. 29, p. 17561-9, Jul 1996. ISSN 0021-9258. Available at: < http://www.ncbi.nlm.nih.gov/pubmed/8663447 >.

NASRALLAH, C. M.; HORVATH, T. L. Mitochondrial dynamics in the central regulation of metabolism. Nat Rev Endocrinol, v. 10, n. 11, p. 650-8, Nov 2014. ISSN 1759-5037. Available at: < https://www.ncbi.nlm.nih.gov/pubmed/25200564 >.

NAYLOR, K. et al. Mdv1 interacts with assembled dnm1 to promote mitochondrial division. The Journal of biological chemistry, v. 281, n. 4, 01/27/2006 2006. ISSN 0021-9258. Available at: < https://www.ncbi.nlm.nih.gov/pubmed/16272155 >.

NEMANI, N.; SHANMUGHAPRIYA, S.; MADESH, M. Molecular regulation of MCU: Implications in physiology and disease. Cell Calcium, v. 74, p. 86-93, Jun 27 2018. ISSN 0143-4160. Available at: < http://dx.doi.org/10.1016/j.ceca.2018.06.006 >.

ODRONITZ, F.; KOLLMAR, M. Drawing the tree of eukaryotic life based on the analysis of 2,269 manually annotated myosins from 328 species. Genome biology, v. 8, n. 9, 2007 2007. ISSN 1474-760X. Available at: $<$ https://www.ncbi.nlm.nih.gov/pubmed/17877792 $>$.

OLICHON, A. et al. The human dynamin-related protein OPA1 is anchored to the mitochondrial inner membrane facing the inter-membrane space. FEBS letters, v. 523, n. 1-3, 07/17/2002 2002. ISSN 00145793. Available at: < https://www.ncbi.nlm.nih.gov/pubmed/12123827 >.

OTERA, H.; ISHIHARA, N.; MIHARA, K. New insights into the function and regulation of mitochondrial fission. Biochim Biophys Acta, v. 1833, n. 5, p. 1256-68, May 2013. ISSN 0006-3002 (Print)0006-3002. Available at: < http://dx.doi.org/10.1016/j.bbamcr.2013.02.002 >.

PASHKOVA, N. et al. Structural basis for myosin $\mathrm{V}$ discrimination between distinct cargoes. The EMBO journal, v. 25, n. 4, 02/22/2006 2006. ISSN 0261-4189. Available at: < https://www.ncbi.nlm.nih.gov/pubmed/16437158 >.

PASTURAL, E. et al. Griscelli disease maps to chromosome $15 q 21$ and is associated with mutations in the myosin-Va gene. Nature genetics, v. 16, n. 3, 1997 Jul 1997. ISSN 1061-4036. Available at: < https://www.ncbi.nlm.nih.gov/pubmed/9207796 >.

PATHAK, D.; SEPP, K. J.; HOLLENBECK, P. J. Evidence that myosin activity opposes microtubule-based axonal transport of mitochondria. J Neurosci, v. 30, n. 26, p. 8984-92, Jun 30 2010. ISSN 1529-2401 (Electronic) 0270-6474 (Linking). Available at: < http://www.ncbi.nlm.nih.gov/pubmed/20592219 > .

PFENDER, S. et al. Spire-type actin nucleators cooperate with Formin-2 to drive asymmetric oocyte division. Curr Biol, v. 21, n. 11, p. 955-60, Jun 7 2011. ISSN 0960-9822. Available at: < http://dx.doi.org/10.1016/j.cub.2011.04.029 >.

PHILLIPS, M.; VOELTZ, G. Structure and function of ER membrane contact sites with other organelles. Nature reviews. Molecular cell biology, v. 17, n. 2, 2016 Feb 2016. ISSN 1471-0080. Available at: < https://www.ncbi.nlm.nih.gov/pubmed/26627931 >. 
PHILLIPS, N. R.; SPROUSE, M. L.; ROBY, R. K. Simultaneous quantification of mitochondrial DNA copy number and deletion ratio: a multiplex real-time PCR assay. Sci Rep, v. 4, p. 3887, Jan 27 2014. ISSN 2045-2322. Available at: < http://dx.doi.org/10.1038/srep03887 >.

POLLARD, T. The cytoskeleton, cellular motility and the reductionist agenda. Nature, v. 422, n. 6933, 04/17/2003 2003. ISSN 0028-0836. Available at: < https://www.ncbi.nlm.nih.gov/pubmed/12700767 >.

POLLARD, T. D.; GOLDMAN, R. D. Overview of the Cytoskeleton from an Evolutionary Perspective. Cold Spring Harb Perspect Biol, v. 10, n. 7, Jul 2 2018. ISSN 1943-0264. Available at: < http://dx.doi.org/10.1101/cshperspect.a030288 >.

PRANCHEVICIUS, M. C. et al. Myosin Va phosphorylated on Ser1650 is found in nuclear speckles and redistributes to nucleoli upon inhibition of transcription. Cell Motil Cytoskeleton, v. 65, n. 6, p. 44156, Jun 2008. ISSN 0886-1544. Available at: < http://dx.doi.org/10.1002/cm.20269 >.

PURCELL, T. et al. Role of the lever arm in the processive stepping of myosin V. Proceedings of the National Academy of Sciences of the United States of America, v. 99, n. 22, 10/29/2002 2002. ISSN 0027-8424. Available at: < https://www.ncbi.nlm.nih.gov/pubmed/12386339>.

PUTHALAKATH, $\mathrm{H}$. et al. Bmf: a proapoptotic $\mathrm{BH} 3$-only protein regulated by interaction with the myosin V actin motor complex, activated by anoikis. Science, v. 293, n. 5536, p. 1829-32, Sep 2001. ISSN 0036-8075. Available at: < http://www.ncbi.nlm.nih.gov/pubmed/11546872 >.

PYLAYEVA-GUPTA, Y.; GRABOCKA, E.; BAR-SAGI, D. RAS oncogenes: weaving a tumorigenic web. Nature reviews. Cancer, v. 11, n. 11, 10/13/2011 2011. ISSN 1474-1768. Available at: < https://www.ncbi.nlm.nih.gov/pubmed/21993244 >.

PYLYPENKO, O. et al. Rab GTPases and their interacting protein partners: Structural insights into Rab functional diversity. Small GTPases, v. 9, n. 1-2, p. 22-48, Mar 4 2018. ISSN 2154-1248. Available at: < http://dx.doi.org/10.1080/21541248.2017.1336191 >.

. Coordinated recruitment of Spir actin nucleators and myosin $\mathrm{V}$ motors to Rab11 vesicle membranes. Elife, v. 5, Sep 13 2016. ISSN 2050-084x. Available at: < http://dx.doi.org/10.7554/eLife.17523 >.

RAMÃO, A.; ESPREAFICO, E. M. A miosina-Va promove a desmontagem das adesões focais e a migração celular. 2014. Doutorado em Biologia Celular e Molecular, Universidade de São Paulo

RASTOGI, A. et al. Remodeling of mitochondrial morphology and function: an emerging hallmark of cellular reprogramming. Cell Stress, v. 3, n. 6, p. 181-194, May 2019. ISSN 2523-0204. Available at: < https://www.ncbi.nlm.nih.gov/pubmed/31225513 >.

ROTTNER, K. et al. Actin assembly mechanisms at a glance. J Cell Sci, v. 130, n. 20, p. 3427-3435, Oct 15 2017. ISSN 0021-9533. Available at: < http://dx.doi.org/10.1242/jcs.206433 >.

RUDOLF, R.; BITTINS, C.; GERDES, H. The role of myosin V in exocytosis and synaptic plasticity. Journal of neurochemistry, v. 116, n. 2, 2011 Jan 2011. ISSN 1471-4159. Available at: < https://www.ncbi.nlm.nih.gov/pubmed/21077886 >. 
RUJIVIPHAT, J. et al. Phospholipid association is essential for dynamin-related protein Mgm1 to function in mitochondrial membrane fusion. The Journal of biological chemistry, v. 284, n. 42, 10/16/2009 2009. ISSN 1083-351X. Available at: < https://www.ncbi.nlm.nih.gov/pubmed/19703904 >.

SAXTON, W. A. H., PJ. The axonal transport of mitochondria. - PubMed - NCBI. 2018. Available at: < https://www.ncbi.nlm.nih.gov/pubmed/ >.

SCHINDELIN, J. et al. Fiji: an open-source platform for biological-image analysis. Nature methods, v. 9, n. 7, 06/28/2012 2012. ISSN 1548-7105. Available at: < https://www.ncbi.nlm.nih.gov/pubmed/22743772 >.

SCHLIWA, M.; WOEHLKE, G. Molecular motors. Nature, v. 422, n. 6933, 04/17/2003 2003. ISSN 00280836. Available at: < https://www.ncbi.nlm.nih.gov/pubmed/12700770 >.

SCHMITT, K. et al. Circadian Control of DRP1 Activity Regulates Mitochondrial Dynamics and Bioenergetics. Cell metabolism, v. 27, n. 3, 03/06/2018 2018. ISSN 1932-7420. Available at: < https://www.ncbi.nlm.nih.gov/pubmed/29478834 >.

SCHREPFER, E.; SCORRANO, L. Mitofusins, from Mitochondria to Metabolism. Mol Cell, v. 61, n. 5, p. 683-694, Mar 3 2016. ISSN 1097-2765. Available at: < http://dx.doi.org/10.1016/j.molcel.2016.02.022 >.

SEBÉ-PEDRÓS, A. et al. Evolution and classification of myosins, a paneukaryotic whole-genome approach. Genome biology and evolution, v. 6, n. 2, 2014 Feb 2014. ISSN 1759-6653. Available at: < https://www.ncbi.nlm.nih.gov/pubmed/24443438 >.

SERASINGHE, M. N. et al. Mitochondrial division is requisite to RAS-induced transformation and targeted by oncogenic MAPK pathway inhibitors. Mol Cell, v. 57, n. 3, p. 521-36, Feb 2015. ISSN 10974164. Available at: < http://www.ncbi.nlm.nih.gov/pubmed/25658204 >.

SHADEL, G.; HORVATH, T. Mitochondrial ROS signaling in organismal homeostasis. Cell, v. 163, n. 3, 10/22/2015 2015. ISSN 1097-4172. Available at: < https://www.ncbi.nlm.nih.gov/pubmed/26496603 >.

SONG, Z. et al. Mitofusins and OPA1 mediate sequential steps in mitochondrial membrane fusion. Molecular biology of the cell, v. 20, n. 15, 2009 Aug 2009. ISSN 1939-4586. Available at: < https://www.ncbi.nlm.nih.gov/pubmed/19477917 >.

STRAUB, F. et al. The SPIRE1 actin nucleator coordinates actin/myosin functions in the regulation of mitochondrial motility. 2020-06-20 $2020 . \quad$ Available at: < https://www.biorxiv.org/content/10.1101/2020.06.19.161109v1 >.

STROM, M. et al. A family of Rab27-binding proteins. Melanophilin links Rab27a and myosin Va function in melanosome transport. The Journal of biological chemistry, v. 277, n. 28, 07/12/2002 2002. ISSN 0021-9258. Available at: < https://www.ncbi.nlm.nih.gov/pubmed/11980908 >.

SUEN, D. F.; NORRIS, K. L.; YOULE, R. J. Mitochondrial dynamics and apoptosis. Genes Dev, v. 22, n. 12, p. 1577-90, Jun 2008. ISSN 0890-9369. Available at: < https://www.ncbi.nlm.nih.gov/pubmed/18559474 >. 
SUN, Y. et al. Myosin Va mediates Rab8A-regulated GLUT4 vesicle exocytosis in insulin-stimulated muscle cells. Mol Biol Cell, v. 25, n. 7, p. 1159-70, Apr 2014. ISSN 1939-4586. Available at: < http://www.ncbi.nlm.nih.gov/pubmed/24478457 >.

SVITKINA, T. The Actin Cytoskeleton and Actin-Based Motility. Cold Spring Harbor perspectives in biology, v. 10, n. 1, 01/02/2018 2018. ISSN 1943-0264. Available at: < https://www.ncbi.nlm.nih.gov/pubmed/29295889 >.

SWeENEY, H. L.; HOLZBAUR, E. L. F. Motor Proteins. Cold Spring Harb Perspect Biol, v. 10, n. 5, May 1 2018. ISSN 1943-0264. Available at: < http://dx.doi.org/10.1101/cshperspect.a021931 >.

Synthego Performance Analysis, ICE Analysis., 2019. Accessed on: Feb 25.

TABB, D. L.; MCDONALD, W. H.; YATES, J. R., 3RD. DTASelect and Contrast: tools for assembling and comparing protein identifications from shotgun proteomics. J Proteome Res, v. 1, n. 1, p. 21-6, JanFeb 2002. ISSN 1535-3893 (Print)1535-3893. Available at: < http://dx.doi.org/ >.

TAKAGISHI, Y. et al. The dilute-lethal (dl) gene attacks a Ca2+ store in the dendritic spine of Purkinje cells in mice. Neurosci Lett, v. 215, n. 3, p. 169-72, Sep 13 1996. ISSN 0304-3940 (Print)0304-3940. Available at: $<$ http://dx.doi.org/ $>$.

THIRUMURUGAN, K. et al. The cargo-binding domain regulates structure and activity of myosin 5 . Nature, v. 442, n. 7099, 07/13/2006 2006. ISSN 1476-4687. Available at: < https://www.ncbi.nlm.nih.gov/pubmed/16838021 >.

TILOKANI, L. et al. Mitochondrial dynamics: overview of molecular mechanisms. Essays Biochem, v. 62, n. 3, p. 341-360, 07 2018. ISSN 1744-1358. Available at: < https://www.ncbi.nlm.nih.gov/pubmed/30030364 >.

TSAI, M. et al. A mitotic lamin B matrix induced by RanGTP required for spindle assembly. Science (New York, N.Y.), v. 311, n. 5769, 03/31/2006 2006. ISSN 1095-9203. Available at: < https://www.ncbi.nlm.nih.gov/pubmed/16543417 >.

VALE, R. The molecular motor toolbox for intracellular transport. Cell, v. 112, n. 4, 02/21/2003 2003. ISSN 0092-8674. Available at: < https://www.ncbi.nlm.nih.gov/pubmed/12600311 >.

VAN DIEPEN, M. T. et al. MyosinV controls PTEN function and neuronal cell size. Nat Cell Biol, v. 11, n. 10, p. 1191-6, Oct 2009. ISSN 1476-4679. Available at: < http://www.ncbi.nlm.nih.gov/pubmed/19767745 >.

VAN GELE, M.; DYNOODT, P.; LAMBERT, J. Griscelli syndrome: a model system to study vesicular trafficking. Pigment cell \& melanoma research, v. 22, n. 3, 2009 Jun 2009. ISSN 1755-1471. Available at: < https://www.ncbi.nlm.nih.gov/pubmed/19243575 >.

VAZQUEZ, F. et al. PGC1 $\alpha$ expression defines a subset of human melanoma tumors with increased mitochondrial capacity and resistance to oxidative stress. Cancer cell, v. 23, n. 3, 03/18/2013 2013. ISSN 1878-3686. Available at: < https://www.ncbi.nlm.nih.gov/pubmed/23416000 >. 
VELVARSKA, H.; NIESSING, D. Structural insights into the globular tails of the human type $v$ myosins Myo5a, Myo5b, And Myo5c. PloS one, v. 8, n. 12, 12/10/2013 2013. ISSN 1932-6203. Available at: < https://www.ncbi.nlm.nih.gov/pubmed/24339992 >.

VYAS, S.; ZAGANJOR, E.; HAIGIS, M. Mitochondria and Cancer. Cell, v. 166, n. 3, 07/28/2016 2016. ISSN 1097-4172. Available at: < https://www.ncbi.nlm.nih.gov/pubmed/27471965 >.

WADA, F. et al. Myosin Va and Endoplasmic Reticulum Calcium Channel Complex Regulates Membrane Export during Axon Guidance. Cell Rep, v. 15, n. 6, p. 1329-44, May 10 2016. Available at: < http://dx.doi.org/10.1016/j.celrep.2016.04.021 >.

WALES, P. et al. Calcium-mediated actin reset (CaAR) mediates acute cell adaptations. Elife, v. 5, Dec 6 2016. ISSN 2050-084X (Electronic)

2050-084X (Linking). Available at: < https://www.ncbi.nlm.nih.gov/pubmed/27919320 >.

WANG, F. et al. Regulated conformation of myosin V. The Journal of biological chemistry, v. 279, n. 4, 01/23/2004 2004. ISSN 0021-9258. Available at: < https://www.ncbi.nlm.nih.gov/pubmed/14634000 >.

WARBURG, O. On the origin of cancer cells. Science, v. 123, n. 3191, p. 309-14, Feb 1956. ISSN 00368075. Available at: < http://www.ncbi.nlm.nih.gov/pubmed/13298683 >.

WELZ, T.; KERKHOFF, E. Exploring the iceberg: Prospects of coordinated myosin V and actin assembly functions in transport processes. Small GTPases, v. 10, n. 2, 2019 Mar 2019. ISSN 2154-1256. Available at: < https://www.ncbi.nlm.nih.gov/pubmed/28394692 >.

WESTBROEK, W. et al. Interactions of human Myosin Va isoforms, endogenously expressed in human melanocytes, are tightly regulated by the tail domain. J Invest Dermatol, v. 120, n. 3, p. 465-75, Mar 2003. ISSN 0022-202X (Print)0022-202x. Available at: < http://dx.doi.org/10.1046/j.15231747.2003.12068.x >.

WESTERMANN, B. Mitochondrial fusion and fission in cell life and death. Nat Rev Mol Cell Biol, v. 11, n. 12, p. 872-84, Dec 2010. ISSN 1471-0080. Available at: < https://www.ncbi.nlm.nih.gov/pubmed/21102612 >.

WU, H.; CARVALHO, P.; VOELTZ, G. Here, there, and everywhere: The importance of ER membrane contact sites. Science (New York, N.Y.), v. 361, n. 6401, 08/03/2018 2018. ISSN 1095-9203. Available at: $<$ https://www.ncbi.nlm.nih.gov/pubmed/30072511 $>$.

WU, X. et al. Rab27a is an essential component of melanosome receptor for myosin Va. Molecular biology of the cell, v. 13, n. 5, 2002 May 2002. ISSN 1059-1524. Available at: < https://www.ncbi.nlm.nih.gov/pubmed/12006666 >.

WU, X. S. et al. Identification of an organelle receptor for myosin-Va. Nat Cell Biol, v. 4, n. 4, p. 271-8, Apr 2002. ISSN 1465-7392 (Print)1465-7392. Available at: < http://dx.doi.org/10.1038/ncb760 >

XIAO, Q. et al. Cytoskeleton Molecular Motors: Structures and Their Functions in Neuron. Int J Biol Sci, v. 12, n. 9, p. 1083-92, 2016. ISSN 1449-2288. Available at: < http://dx.doi.org/10.7150/ijbs.15633 $>$. 
XIE, Q. et al. Mitochondrial control by DRP1 in brain tumor initiating cells. Nat Neurosci, v. 18, n. 4, p. 501-10, Apr 2015. ISSN 1546-1726. Available at: < http://www.ncbi.nlm.nih.gov/pubmed/25730670 $>$.

$X U$, T. et al. ProLuCID: An improved SEQUEST-like algorithm with enhanced sensitivity and specificity. J Proteomics, v. 129, p. 16-24, Nov 3 2015. ISSN 1874-3919. Available at: < http://dx.doi.org/10.1016/j.jprot.2015.07.001 >.

YANG, C.; SVITKINA, T. M. Ultrastructure and dynamics of the actin-myosin II cytoskeleton during mitochondrial fission. Nat Cell Biol, v. 21, n. 5, p. 603-613, May 2019. ISSN 1465-7392. Available at: < http://dx.doi.org/10.1038/s41556-019-0313-6 >.

YOSHIZAKI, T. et al. Myosin $5 a$ is an insulin-stimulated Akt2 (protein kinase Bbeta) substrate modulating GLUT4 vesicle translocation. Mol Cell Biol, v. 27, n. 14, p. 5172-83, Jul 2007. ISSN 02707306. Available at: < http://www.ncbi.nlm.nih.gov/pubmed/17515613 $>$.

YOULE, R. J.; VAN DER BLIEK, A. M. Mitochondrial fission, fusion, and stress. Science, v. 337, n. 6098, p. 1062-5, Aug 2012. ISSN 1095-9203. Available at: < https://www.ncbi.nlm.nih.gov/pubmed/22936770 >.

ZENZEN, J. A. R.; ESPREAFICO, E. M. Myosin-Va assists in the transport of Dynamin-2 and Clathrin to focal adhesions and promotes their disassembly. 2019. text Universidade de São Paulo

ZHANG, N.; YAO, L.; LI, X. Regulation of class V myosin. Cellular and molecular life sciences : CMLS, v. 75 , n. 2, 2018 Jan 2018. ISSN 1420-9071. Available at: < https://www.ncbi.nlm.nih.gov/pubmed/28730277 >.

ZHANG, W.; YAO, L.; LI, X. The Globular Tail Domain of Myosin-5a Functions as a Dimer in Regulating the Motor Activity. The Journal of biological chemistry, v. 291, n. 26, 06/24/2016 2016. ISSN 1083351X. Available at: < https://www.ncbi.nlm.nih.gov/pubmed/27129208 >.

ZHAO, J. et al. Human MIEF1 recruits Drp1 to mitochondrial outer membranes and promotes mitochondrial fusion rather than fission. Embo j, v. 30, n. 14, p. 2762-78, Jun 24 2011. ISSN 0261-4189. Available at: $<$ http://dx.doi.org/10.1038/emboj.2011.198 $>$.

Mitochondrial dynamics regulates migration and invasion of breast cancer cells. Oncogene, v. 32, n. 40, p. 4814-24, Oct 2013. ISSN 1476-5594. Available at: < http://www.ncbi.nlm.nih.gov/pubmed/23128392 >. 


\section{Apêndices}

Filme Suplementar 1. Vídeo-microscopia Aryscan de super-resolução de células A375 coradas com MitoTracker DeepRed (magenta); além de transfectadas com mitoSpire1 inteira (mStb-mitoSpire1FL, vermelho), com o construto da cauda medial globular damiosina-Va (MGT-GFP, ciano) e ER-BFP (retículo endoplasmático, amarelo), mostrando a dinâmica da rede mitocondrial e localização dos outros marcadores.

Filme Suplementar 2. Vídeo-microscopia de super-resolução Airscan de células U2OS mostrando a localização de MVaFL-GFP (verde) juntamente com a mitocondria corada com MitoTracker DeepRed em uma condição não tratada, como controle, e mostrando a dinâmica da rede mitocondrial e localização de MVaFL-GFP em relação a mitocôndria.

Filme Suplementar 3. Vídeo-microscopia de super-resolução Airscan de células U2OS mostrando a localização de MVaFL-GFP (verde) juntamente com a mitocondria corada com MitoTracker DeepRed em uma condição tratada com ionomicina, e mostrando a dinâmica da rede mitocondrial e localização de MVaFL-GFP em relação a mitocôndria.

Filme Suplementar 4. Vídeo-microscopia de super-resolução Aryscan de U20S WT. As células foram coradas com MitoTracker DeepRed (magenta) e transfectadas com um construto da cauda inteira da miosina-Va (MVaFT-GFP, verde). O vídeo mostra um local de fissão mitocondrial e a localização de MVaFT-GFP relacionada à esse local de fissão.

Filme Suplementar 5. Vídeo-microscopia de super-resolução Aryscan de U20S mitoSpire1KO. As células foram coradas com MitoTracker DeepRed (magenta) e transfectadas com um construto da cauda inteira da miosina-Va (MVaFT-GFP, verde). O vídeo mostra um local de fissão mitocondrial e a localização de MVaFT-GFP relacionada à esse local de fissão.

Filme Suplementar 6. Vídeo-microscopia de super-resolução Aryscan de células U20S WT. As células foram coradas com MitoTracker DeepRed (magenta) e transfectadas com um construto da cauda inteira da miosina-Va (MVaFT-GFP, amarelo), e Drp1 (Drp1-mCherry, ciano). O vídeo mostra um local de fissão e a localização de MVaFT-GFP e Drp1-mCherry relacionadas a esse local de fissão. 
Filme Suplementar 7. Vídeo-microscopia de super-resolução Aryscan de células U20S mitoSpire1KO. As células foram coradas com MitoTracker DeepRed (magenta) e transfectadas com um construto da cauda inteira da miosina-Va (MVaFT-GFP, amarelo), e Drp1 (Drp1mCherry, ciano). O vídeo mostra um local de fissão e a localização de MVaFT-GFP e Drp1mCherry relacionadas a esse local de fissão.

Filme Suplementar 8. Vídeo-microscopia de super-resolução Aryscan de células U20S WT. As células foram coradas com MitoTracker DeepRed (magenta) e transfectadas com um construto da cauda inteira da miosina-Va (MVaFT-GFP, amarelo), e Rab11a (Rab11-mApple, em ciano). O vídeo mostra um local de fissão e a localização de MVaFT-GFP e Rab11-mApple relacionada a esse local de fissão.

Filme Suplementar 9. Vídeo-microscopia de super-resolução Aryscan de células U20S mitoSpire1KO. As células foram coradas com MitoTracker DeepRed (magenta) e transfectadas com um construto da cauda inteira da miosina-Va (MVaFT-GFP, amarelo), e Rab11a (Rab11mApple, em ciano). O vídeo mostra um local de fissão e a localização de MVaFT-GFP e Rab11mApple relacionada a esse local de fissão.

Filme Suplementar 10. Vídeo-microscopia de super-resolução Aryscan de células A375 sh CTRL mostrando a rede mitocondrial corada com MitoTracker DeepRed (magenta), mostrando a dinâmica da rede mitocondrial e os eventos de fissão.

Filme Suplementar 11. Vídeo-microscopia de super-resolução Aryscan de células A375 silenciadas miosina-Va (shMVa2), mostrando a rede mitocondrial corada com MitoTracker DeepRed (magenta), mostrando a dinâmica da rede mitocondrial e os eventos de fissão.

Filme Suplementar 12. Vídeo-microscopia de super-resolução Aryscan de células A375 WT mostrando a rede mitocondrial corada com MitoTracker DeepRed (magenta), mostrando a dinâmica da rede mitocondrial e os eventos de fissão.

Filme Suplementar 13. Vídeo-microscopia de super-resolução Aryscan de células A375 nocauteadas para miosina-Va (MYO5AKO4 e MYO5A KO5) mostrando a rede mitocondrial corada com MitoTracker DeepRed (magenta), mostrando a dinâmica da rede mitocondrial e os 
eventos de fissão. 
Os filmes suplementares se encontram disponíveis online, no link:

https://www.dropbox.com/sh/pc85jrbfi8i8efo/AAB4Y-n7MYgSnhbbvnIm2Lg8a?dl=0

Figura Suplementar 1. Membranas inteiras dos western blots apresentados no trabalho.

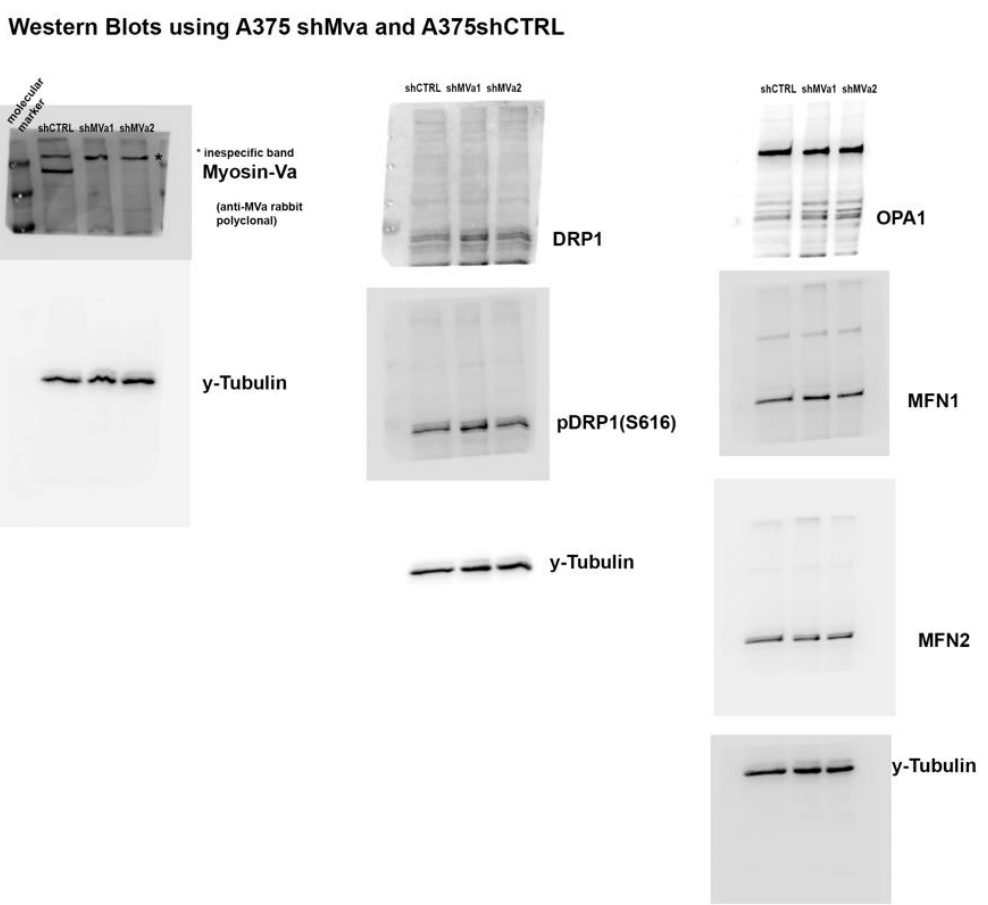


Western Blots using A375 WT and MYO5A KO cells
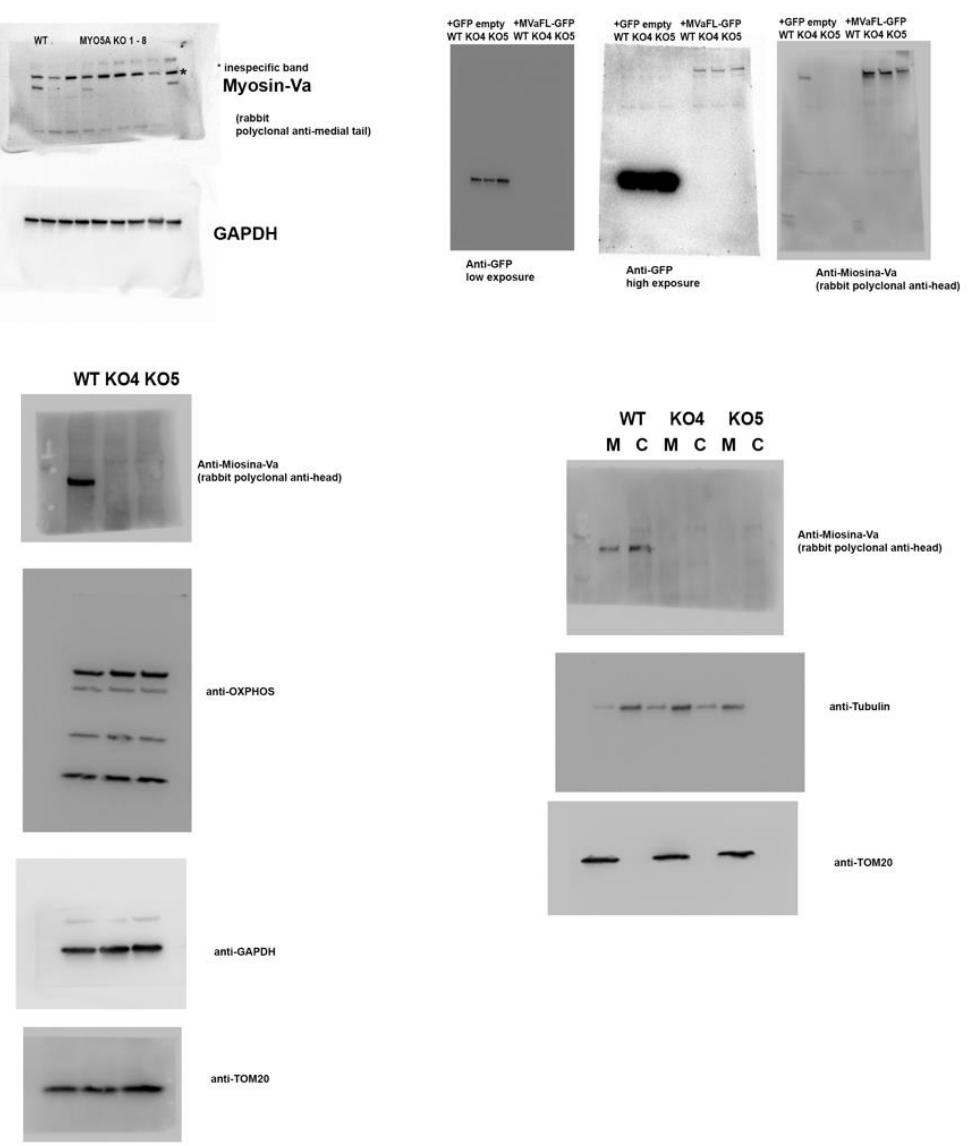

WT KO4 KO5

M C M C M C
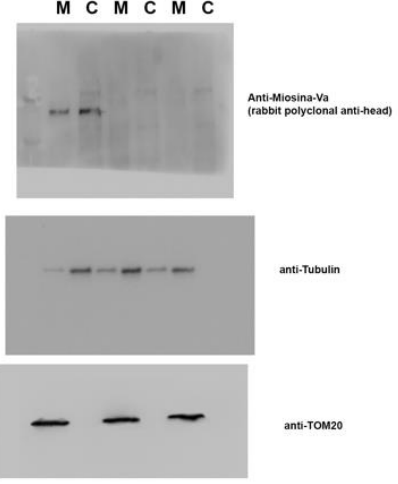